\title{
A racionalidade da mercantilização da doença
}

\author{
Marcelo Ferreira Carlos Cunha
}

Dissertação apresentada ao Programa de Pós-Graduação em Saúde Pública da Faculdade de Saúde Pública da Universidade de São Paulo para a obtenção do título de Mestre em Saúde Pública.

Área de Concentração: Serviços de Saúde Pública

Orientador: Prof. Dr. Laurindo Dias Minhoto

São Paulo 2008 
É expressamente proibida a comercialização deste documento tanto na sua forma impressa como eletrônica. Sua reprodução total ou parcial é permitida exclusivamente para fins acadêmicos e científicos, desde que na reprodução figure a identificação do autor, título, instituição e ano da tese/dissertação.

Cunha, Marcelo Ferreira Carlos

A racionalidade da mercantilização da doença. [dissertação de mestrado]. São Paulo: Faculdade de Saúde Pública da USP; 2008.

Orientador: Minhoto, Laurindo Dias

Palavras-chave: Medicamentos; Política de Medicamentos; Assistência Farmacêutica; Vigilância Sanitária; Mercantilização

Keywords: Drugs; Drug policy; Pharmaceutical Care; Health surveillance; Commodification 
Aos meus pais, Maria Celsa Ferreira e Clemente Carlos Cunha, pelo amor que me deram e pelos valores que me transmitiram.

A minha família, Fabiana, Marcela e Matheus, (não muito tradicional, graças a Deus) por tudo, mas, principalmente, pela compreensão de minhas ausências. 


\section{Agradecimentos}

Ao professor Laurindo que, diferente da expectativa que muitos criam sobre o orientador, foi sempre extremamente generoso, disponível e acessível. Por me ter dado total liberdade sem, no entanto, abster-se de orientar como se caminha num trabalho científico.

Ao professor Júlio César Pereira, meu primeiro professor na FSP, por ensinar que pesquisar é apaixonar-se e por me apresentar Ivan Illich, fundamental para este trabalho.

A professora Maria da Penha Vasconcellos pela força e pelas "duras" discussões em sala de aula, fundamentais para a compreensão do que é um trabalho científico.

Ao grande amigo Rogério Renato Silva pelos cafés, almoços e jantares que me fizeram refletir sobre uma série de questões, motivado-me a trabalhar nos momentos mais angustiantes e, principalmente, pela imensa generosidade de abrir as portas de sua casa e me emprestar valiosos livros de sua biblioteca particular.

Aos colegas das disciplinas cursadas na FSP/USP e FFLCH/USP pelos bate-papos informais que, de tão importantes, deveriam contar como créditos e por compartilharem as angústias e alegrias desta viagem. 


\section{Resumo}

Na década de 90 se inicia um debate nos países de língua inglesa sobre uma nova forma de relação entre a indústria e a doença. O novo fenômeno em questão foi batizado de disease mongering (mercantilização da doença), no qual a estratégia básica da indústria é a ampliação dos limites da doença para o aumento de seu mercado consumidor. O debate deste fenômeno se estende com publicações pela década de 2000 discutindo como a indústria faz alianças com o governo, médicos e meios científicos que fortalecem o estabelecimento de concepções de doença que favorecem a venda de seus tratamentos. Propõe-se discutir esse fenômeno articulando-o a outros três conceitos: o uso racional de medicamentos, a medicalização e a racionalidade técnica. O primeiro para definir os critérios do uso racional de medicamentos e verificar se o fenômeno da mercantilização da doença proporciona relação de afastamento ou de a aproximação com esses critérios. O segundo para estabelecer a relação entre a mercantilização da doença e a medicalização da sociedade, a partir dos termos do próprio debate que definem a mercantilização da doença como uma forma de medicalização. O terceiro para se aprofundar naquilo que está na base do fenômeno da mercantilização da doença: a sobreposição de lógicas. Principalmente a sobreposição da lógica mercantil à lógica sanitária. Para isto, o estudo faz uma incursão pelos referenciais teóricos que examinam a racionalidade técnica, sobretudo a tradição crítica de Marcuse e Horkheimer. Na raiz dessas formulações, encontram-se o conceito de reificação, de Lukács, e o conceito de fetichismo da mercadoria, de Marx. Esses referenciais teóricos permitem discutir o sentido e o alcance da sobreposição de lógicas subjacente à mercantilização da doença.

Como resultados, a pesquisa mostra que a mercantilização da doença desvirtua progressivamente os parâmetros fixados para o URM e que reforça a medicalização da sociedade. Nesse processo, a racionalidade técnica reconfigura a prática e o saber médicos. A mercantilização da doença 
permite vislumbrar, ainda, a colonização econômica de outras esferas da sociedade, tais como a educação, a política e a ciência, possibilitando que a esfera econômica colonize o sistema de saúde da sociedade contemporânea.

Palavras-chave: Medicamentos; Política de Medicamentos; Assistência Farmacêutica; Vigilância Sanitária; Mercantilização. 


\section{Abstract}

A debate on a new form of relation between industry and disease is started during the 90's in English speaking countries. The new phenomenon in question was then called disease mongering, whose basic industry strategy was to expand disease boundaries in order to grow its consumer market. In the 2000's, publications widen the debate on such phenomenon and discuss how alliances between drug industry and government, doctors and the scientific community are formed, strengthening conceptions about diseases which promote treatment sale. I aim to discuss such phenomenon through its articulation with three conceptions: drug rational use, medicalization and technical rationality. The first one defines the criteria for drug rational use and verifies if the disease mongering phenomenon promotes an independent or a close relationship with such criteria. The second one establishes the relation between disease mongering and society medicalization from data provided by the debate itself, which defines disease mongering as a way of medicalization. The third one goes deep into what the basis of the disease mongering phenomenon is: logical overlapping, especially that of mercantile logic over sanitary logic. Thus, this study promotes a reflection on the theoretical references that assess technical rationality, especially Marcuse and Horkheimer's critical tradition. In the root of such formulations there are Lukács' reification concept, and Marx's concept of goods fetishism. Such theoretical references allow discussing the sense and the reach of logical overlapping underlying disease mongering.

The results of this research show that disease mongering tends to progressively misrepresent the established parameters for URM and reinforce society medicalization. In this process, technical rationality reshapes medical practice and knowledge. Disease mongering also allows analyzing the economical colonization of other society spheres, such as education, politics and science, making it possible for the economical sphere to colonize the health system in the contemporary society. 
Keywords: Drugs; Drug policy; Pharmaceutical Care; Health Surveillance; Commodification. 


\section{ÍNDICE}

INTRODUÇÃO

OBJETIVO

1. O DEBATE SOBRE O USO RACIONAL DE MEDICAMENTOS (URM) 21

1.1 UM BREVE HISTÓRICO SOBRE A NECESSIDADE DE DISCUTIR O USO RACIONAL DE MEDICAMENTOS

1.2 PRINCIPAIS QUESTÕES SOBRE O USO RACIONAL DE MEDICAMENTOS

1.2.1 Acesso aos Medicamentos

1.2.2 Uso Correto dos Medicamentos

1.2.2.1 Definições e Questões Sobre os Critérios

para o Uso Correto dos Medicamentos:

Eficácia, Efetividade, Eficiência e Segurança 28

1.2.2.2 Segurança / Reações Adversas

1.2.2.3 Fatores que Influenciam os Critérios para o Uso

Correto dos Medicamentos

1.2.2.3.1 Lançamento de Novos Produtos Pela Indústria Farmacêutica e a Grande Quantidade de "Diferentes Medicamentos" no Mercado

1.2.2.3.2 Propaganda de Medicamentos

1.3 ALGUMAS AÇÕES POLÍTICAS RELACIONADAS AO URM 43

1.3.1 Lista de Medicamentos Essenciais

1.3.2 Definição de Uso Racional de Medicamentos

1.3.3 Diretrizes para Políticas de Medicamentos

1.3.4 Entidades Participantes na Discussão do URM

1.3.5 As Câmaras Técnicas no Sistema Brasileiro de 
1.3.6 Fatos Recentes no Debate Sobre o Uso Racional de Medicamentos

1.4 O URM E A MERCANTILIZAÇÃO DA DOENÇA

2. O DEBATE SOBRE A MERCANTILIZAÇÃO DA DOENÇA

2.1 CONCEITUANDO DISEASE MONGERING 53

2.2 ANTECEDENTES HISTÓRICOS - OS NOSTRUM MONGERS 54 2.3 A INTENSIFICAÇÃO DO FENÔMENO "MERCANTILIZAÇÃO

DA DOENÇA" E O SURGIMENTO DO DEBATE 60

2.4 O CONTEXTO HISTÓRICO CONTEMPORÂNEO DA INDÚSTRIA FARMACÊUTICA 65

2.4.1 Pesquisa e Desenvolvimento 66

2.4.1.1 Etapas de Pesquisa e Desenvolvimento 68

2.4.2 A Extensão da Vigência das Patentes Existentes $\quad 71$

2.4.3 O Papel que a Indústria Farmacêutica Assumiu: da Imagem em Inovação em Pesquisa à Realidade de uma Empresa Especializada em Marketing e Lobby 71

2.5 CASOS DISCUTIDOS NO DEBATE SOBRE A MERCANTILIZAÇÃO DA DOENÇA 73

2.5.1 O Primeiro Caso Histórico Recente - A Halitose (DOSSEY, 2006) 73

2.5.2 O Colesterol (MOYNIHAN e CASSELS, 2005) 75

2.5.3 A Depressão (MOYNIHAN e CASSELS, 2005) 77

2.5.4 A Disfunção Erétil [DE] (LEXCHIN, 2006) 79

2.5.5 A Hiperatividade (PHILLIPS, 2006) 82

2.5.6 A Disfunção Sexual Feminina [DSF] (TIEFER, 2006) 84

2.5.7 O Transtorno Bipolar (HEALY, 2006) 87

2.5.8 A Síndrome das Pernas Inquietas [SPI]

(WOLOSHIN e SCHWARTZ, 2006) 91 
3. A MEDICALIZAÇÃO E A RACIONALIDADE TÉCNICA 95

3.1 O FENÔMENO DA MEDICALIZAÇÃO 96

3.2 A RACIONALIDADE TÉCNICA 100

3.2.1 O Valor de Uso e o Valor de Troca 101

3.2.2 O Caráter Fetichista da Mercadoria 103

3.2.3 O Fenômeno da Reificação 106

3.2.4 A Objetivação do Fetichismo da Mercadoria 110

3.2.5 Mercado: Uma Forma Específica de Sociabilidade $\quad 112$

3.2.6 A Reificação da Razão: A Racionalidade Técnica 116

4. O MEDICAMENTO NO UNIVERSO DA RACIONALIDADE TÉCNICA 127

CONSIDERAÇÕES FINAIS 144

$\begin{array}{ll}\text { REFERÊNCIAS } & 146\end{array}$

$\begin{array}{ll}\text { ANEXO } & 158\end{array}$ 


\section{Lista de Tabelas e Anexos}

Tabela 1 - Perfil do consumo brasileiro de medicamentos, segundo a faixa de renda da população

Tabela 2 - Comparativo entre os gastos com marketing e pesquisa e desenvolvimento das 11 maiores indústrias farmacêuticas

Anexo - $\quad$ Campanha publicitária para popularizar a andropausa deflagrada em novembro de 2006 pela empresa Shering, do grupo Bayer Shering Pharma 


\section{Siglas Utilizadas}

\begin{tabular}{|c|c|c|}
\hline ABIFARMA & - & Associação Brasileira da Indústria Farmacêutica \\
\hline ADDISS & - & $\begin{array}{l}\text { National Attention Déficit Disorder Information and } \\
\text { Support Service }\end{array}$ \\
\hline AIS & - & Ação Internacional para Saúde \\
\hline ANVISA & - & Agência Nacional de Vigilância Sanitária \\
\hline APA & - & Associação Psiquiátrica Americana \\
\hline CAAM & - & $\begin{array}{l}\text { Comissão de Assessoramento para Assuntos de } \\
\text { Medicamentos }\end{array}$ \\
\hline CATEME & - & Câmara Técnica de Medicamentos \\
\hline CEATOX & - & $\begin{array}{l}\text { Centro de Assistência Toxicológica do Hospital das } \\
\text { Clínicas da Universidade de São Paulo }\end{array}$ \\
\hline CEBRIM/DF & - & Centro Brasileiro de Informações sobre Medicamentos \\
\hline CEME & - & Central de Medicamentos \\
\hline CFF & - & Conselho Federal de Farmácia \\
\hline CHADD & - & $\begin{array}{l}\text { Children and Adults with Attention Déficit / Hiperactivity } \\
\text { Disorder }\end{array}$ \\
\hline CNMM & - & Centro Nacional de Monitorização de Medicamentos \\
\hline CONATEM & - & $\begin{array}{l}\text { Comissão Nacional de Avaliação Técnica de } \\
\text { Medicamentos (1986) }\end{array}$ \\
\hline CONATEM & - & $\begin{array}{l}\text { Comissão Nacional de Assessoramento Técnico- } \\
\text { Científico em Medicamentos (1997) }\end{array}$ \\
\hline CPI & - & Comissão Parlamentar de Inquérito \\
\hline CRAME & - & $\begin{array}{l}\text { Comissão Técnica de Assessoramento em Assuntos de } \\
\text { Medicamentos e Correlatos }\end{array}$ \\
\hline CRF-SP & - & Conselho Regional de Farmácia do Estado de São Paulo \\
\hline $\mathrm{DE}$ & - & Disfunção Erétil \\
\hline DIMED/SNV & S- & $\begin{array}{l}\text { Divisão Nacional de Medicamentos / Sistema Nacional } \\
\text { de Vigilância Sanitária }\end{array}$ \\
\hline DSF & - & Disfunção Sexual Feminina \\
\hline
\end{tabular}




$\begin{array}{lll}\text { DSM } & - & \text { Diagnsotic and Statistical Manual of Mental Disorder } \\ \text { FDA } & - & \text { Food and Drug Administration } \\ \text { GPUIM } & - & \text { Grupo de Prevenção ao Uso Indevido de Medicamentos } \\ \text { IDEC } & - & \text { Instituto Brasileiro de Defesa de do Consumidor } \\ \text { IDUM } & - & \text { Instituto Brasileiro de Defesa do Usuário de } \\ & & \text { Medicamentos } \\ \text { IMS } & - & \text { Intercontinental Marketing Services } \\ \text { MIT } & - & \text { Instituto Tecnológico de Massachussets } \\ \text { MS } & - & \text { Ministério da Saúde do Brasil } \\ \text { NIH } & - & \text { National Institutes of Health } \\ \text { NME } & - & \text { New Molecular Entity } \\ \text { OMS } & - & \text { Organização Mundial da Saúde } \\ \text { OPAS } & - & \text { Organização Pan Americana da Saúde } \\ \text { RAM } & - & \text { Reação Adversa ao Medicamento } \\ \text { RDC } & - & \text { Resolução da Diretoria Colegiada da ANVISA } \\ \text { RENAME } & - & \text { Relação Nacional de Medicamentos } \\ \text { SINITOX } & - & \text { Sistema Nacional de Informações Tóxico- } \\ & & \text { Farmacológicas } \\ \text { SISMED } & - & \text { Sistema Brasileiro de Informação sobre Medicamentos } \\ \text { SOBRAVIME } & - & \text { Sociedade Brasileira de Vigilância de Medicamentos } \\ \text { SPI } & - & \text { Síndrome das Pernas Inquietas } \\ \text { TDAH } & - & \text { Transtorno pelo déficit de atenção / hiperatividade } \\ \text { UFC } & - & \text { Universidade Federal do Ceará } \\ \text { UFSC } & - & \text { Universidade Federal de Santa Catarina } \\ \text { URM } & - & \text { Uso Racional de Medicamentos }\end{array}$




\section{APRESENTAÇÃO}

Em 2005, cursei a disciplina "Direito Sanitário: aspectos sociais e filosóficos", ministrada pelo professor Doutor Laurindo Dias Minhoto, que foi o primeiro a me ensinar sobre a teoria Marxista, entre outras teorias abordadas naquela disciplina. Em agosto do mesmo ano, há exatos três anos, apresentei minha primeira abordagem sobre o tema desta dissertação num trabalho de doze páginas que serviu de avaliação para aquele curso. $O$ trabalho intitulava-se "medicamento: uma ferramenta terapêutica $x$ um produto comercial". Daí para frente o professor Laurindo não parou de me indicar uma série de referências bibliográficas e disciplinas que ampliaram a visão sobre o mundo que estava a minha frente. Dessas indicações, duas foram fundamentais: o livro "O medicamento como mercadoria simbólica", do Prof. Fernando Lefèvre da FSP/USP e a disciplina "Karl Marx e os Marxismos" do Prof. Ricardo Musse, da FFLCH/USP. Esse foi o início da construção desta dissertação de mestrado.

Neste caminho, a questão do que seria a "verdade" sempre foi o aspecto de maior questionamento pessoal. Perante tantas linhas filosóficas, tantas possíveis interpretações, fatos que poderiam estar distorcidos em favor desta ou daquela tese, como obter uma "verdade" ou "possível verdade"?

Um fato recente mudou meu pensamento sobre esta angustia. Não faz muito tempo, estava atirando pedras em um lago e, ao observar o reflexo do mundo real nas ondas circulares e progressivas provocadas pelo impacto da pedra sobre a água, percebi que, entre essas ondas, este reflexo não ficava contínuo; ele apresentava-se sob forma de faixas intercaladas. Compreendi então, que a imagem refletida não era a realidade e nem tampouco o seu exato reflexo, mas partes que tentamos interpretar remontando os pedaços que faltam, de acordo com nosso próprio repertório de referências. 
Hoje, é desta forma que penso que seja o espírito desta dissertação. Nem de perto ela pode ser considerada como a verdade (ou realidade); nem que sua construção teórica reflita exatamente a realidade que está à frente dos nossos olhos. Ela é uma tentativa de remontar e compreender uma realidade a partir de seus fractais por meio de um repertório de referências próprio - o que não deixa, ao meu ver, de ter sua validade científica. Pois me parece que isto é intrínseco a própria forma como se constrói conhecimento ou se faz ciência.

De qualquer forma, entendo - e insisto - que não deixa de ter validade porque o próprio conceito de realidade (ou verdade) absoluta é algo ainda perseguido no campo filosófico. E acredito, finalmente, que esta validade esteja na busca honesta da compreensão do fenômeno que o pesquisador se propõe a estudar, resgatando para isso, referenciais teóricos que tentam apreender ao máximo, os meandros do reflexo dis 


\section{INTRODUÇÃO}

Em 1992, a jornalista americana Lynn Payer lança, nos Estados Unidos, o livro Disease mongers: how doctors, drugs companies, and insurers are making you feel sick. Nesse livro, a jornalista denuncia que a indústria farmacêutica está ampliando seu mercado consumidor pelo desenvolvimento de novas concepções de doença com o propósito de aumentar a venda de seus tratamentos. A indústria passa a "mercantilizar a doença". PAYER (1992) cria, então, o termo disease monger, que será popularizado mais tarde num debate intensificado nos países de língua inglesa.

Este debate toma vulto nos anos 2000 com uma série de publicações, algumas das quais serão objetos de estudo desta dissertação.

Ray Moynihan, jornalista australiano, destaca-se por popularizar o termo disease mongering, a partir de uma série de publicações, entre as quais, destaca-se o livro Selling sickness: how the world's biggest pharmaceutical companies are turning us all into patients, lançado em 2005.

Em 2006, na Austrália, é realizado o I Congresso Mundial sobre a mercantilização das doenças. $O$ evento relaciona a discussão sobre a criação das doenças com questões da patologização (ou medicalização) e comodificação da sociedade. Torna-se cada vez mais evidente a articulação existente entre estas questões.

Paralelamente a este debate, outra discussão relacionada ao universo dos medicamentos vem se travando desde os anos 70: o uso racional de medicamentos (URM). Esta discussão, embora um pouco mais restrita ao meio acadêmico, é abraçada por entidades públicas e civis, sobejamente a Organização Mundial da Saúde, na busca de disciplinar o uso do medicamento de maneira que sua utilização seja feita de forma correta (ou racional), seguindo critérios científicos, em contraposição ao uso indiscriminado (ou irracional) historicamente estabelecido. Provavelmente, o marco teórico mais importante deste debate foi a Conferência de 
Especialistas em Uso Racional de Medicamentos da OMS, realizada em Nairobi, Quênia, em 1985, quando se estabelece a definição de uso racional de medicamentos que é utilizada até hoje.

A constatação da coexistência desses dois debates, não só distintos, mas também contrapostos, instiga a seguinte questão: se existe uma definição de uso racional de medicamentos com critérios racionais de utilização, como é possível o estabelecimento da mercantilização da doença, em que a utilização dos medicamentos está sendo "irracionalizada" pelas novas concepções deste fenômeno? Ou melhor: qual é esta "outra" racionalidade que está regendo este fenômeno? E ainda: como opera esta racionalidade?

Na busca destas respostas e por se tratar de fenômeno relacionado com o conceito de comodificação, este trabalho resgatará o referencial teórico que examina a racionalidade técnica encontrada nas reflexões de MARCUSE (1967) e HORKHEIMER (1976), baseadas em concepções de LUKÁCS (2003) e MARX (1985).

Para articular este referencial teórico com os fenômenos estudados, um outro elemento se mostrará necessário: o conceito de medicalização. $O$ próprio debate da mercantilização da doença considera este fenômeno como uma forma de medicalização.

Dessa forma, este trabalho está dividido em quatro capítulos, além das considerações finais, a saber:

- Capítulo um: Elabora-se breve histórico acerca do URM, englobando as principais questões e ações políticas relativas a esse tema.

- Capítulo dois: Apresenta-se o debate contemporâneo sobre a mercantilização da doença. Primeiramente, será feita uma conceituação do termo "mercantilização da doença". Em seguida, serão apresentados os antecedentes históricos, o contexto atual que propiciou a intensificação desse fenômeno e, por fim, serão 
apresentados alguns casos discutidos no debate sobre a mercantilização da doença.

- Capítulo três: Analisa-se o fenômeno da medicalização e alguns aspectos da constituição da racionalidade técnica, forma hegemônica do pensamento atual, a partir do conceito de fetichismo da mercadoria.

- Capítulo quatro: Procura articular e desenvolver as questões apresentadas nos três capítulos anteriores. 


\section{OBJETIVO}

O objetivo deste trabalho é discutir o fenômeno da mercantilização da doença, articulando-o a três conceitos fundamentais: o uso racional de medicamentos, a medicalização e a racionalidade técnica.

O primeiro para definir os critérios do uso racional de medicamentos e verificar se o fenômeno da mercantilização da doença proporciona relação de afastamento ou de aproximação com estes critérios.

O segundo para estabelecer a relação entre mercantilização da doença e medicalização da sociedade, a partir do próprio debate que define a mercantilização da doença como uma forma de medicalização.

O terceiro para se aprofundar no que está na base do fenômeno da mercantilização da doença: a sobreposição de lógicas. Principalmente a sobreposição da lógica mercantil à lógica sanitária. 


\section{O DEBATE SOBRE O USO RACIONAL DE MEDICAMENTOS (URM)}

Neste capítulo será apresentado um breve histórico do porquê surgiu o debate sobre o uso racional dos medicamentos, as principais questões com relação ao URM, bem como algumas ações políticas derivadas deste debate.

O debate sobre o URM emerge em função das conseqüências do uso indiscriminado de medicamentos ${ }^{1}$.

A primeira seção deste capítulo tem a intenção de discutir a importância do papel do medicamento na terapêutica recente, o que amplifica as conseqüências negativas do uso indiscriminado nos termos deste debate.

A segunda seção objetiva sistematizar o debate sobre o URM e apresenta dois aspectos centrais: a falta de acesso aos medicamentos para algumas populações e, em contraste, o uso indiscriminado (ou irracional) que ocorre nas populações que têm acesso aos medicamentos.

No intuito de dar clareza a este aspecto, a segunda seção irá trabalhar com quatro critérios técnicos adotados como norteadores para o uso racional dos medicamentos: eficácia, efetividade, eficiência e segurança. Devido ao contexto do modelo econômico no qual o uso de medicamentos está inserido, estes quatro critérios são fortemente influenciados por uma série de fatores, dentre os quais a grande quantidade de novos produtos lançados no mercado e a forte propaganda médica movida pela indústria farmacêutica. A forma como se apresenta essa influência é complexa, em primeiro lugar porque o que se entende como novo produto nessa indústria é algo bastante controverso, subjugando as regras de mercado, que deveriam ser eminentemente definidas por aspectos técnicos e científicos. Em segundo lugar pela enorme influência da propaganda médica nas

\footnotetext{
${ }^{1}$ Uso indiscriminado dos medicamentos é um termo largamente encontrado na literatura sobre URM. Basicamente é o uso sem discernimento, sem avaliação ou sem conhecimento. É o oposto do uso racional, o qual a definição se encontra na seção 1.3.2 deste trabalho.
} 
prescrições de medicamentos. Por isso, esses dois fatores também merecerão uma seção específica.

A terceira (e última) seção deste capítulo tem o intuito de apresentar algumas ações políticas que resultaram deste debate. Estas ações são conseqüências de movimentos de instituições que, preocupadas com 0 crescente uso indiscriminado de medicamentos, têm discutido e criado algumas ferramentas na tentativa de estabelecer o uso racional dos medicamentos.

\subsection{UM BREVE HISTÓRICO SOBRE A NECESSIDADE DE DISCUTIR O USO RACIONAL DE MEDICAMENTOS}

Segundo TOGNONI e LAPORTE (1989), "a terapêutica farmacológica atual é uma prática relativamente recente". Apesar dos avanços das ciências químicas e fisiológicas do século XIX, os grandes avanços terapêuticos ocorreram a partir do primeiro terço do século $X X$, com a introdução de barbitúricos, dos arsenicais e da insulina. Somente a partir dos anos 40 inicia-se uma introdução maciça de novos fármacos. Em 1936 se introduzem a sulfamidas, em 1941 a penicilina e em 1948 a clortetraciclina e o cloranfenicol (TOGNONI e LAPORTE, 1989). Durante as décadas de 40 e 50 , surge a indústria farmacêutica global, com o desenvolvimento, em escala muito maior, de novos produtos (BERMUDEZ, 1995). A partir dos anos 50 e 60 , a curva de registros de patentes passa a ser logarítmica. Do primeiro emprego do salicilato de sódio, como antipirético, por Buss, em 1875, até o desenvolvimento dos antagonistas do receptor $\mathrm{H}_{2}$ da histamina, por Black, em 1972, acumulam-se cerca de sete mil patentes de produtos químicofarmacêuticos (CASTRO e col., 2000).

O crescente número de fármacos e especialidades farmacêuticas trouxe consigo, inegavelmente, uma série de efeitos benéficos, por um lado, mas também, e conseqüentemente, uma série de problemas por outro. 
Surgem novas questões que exploraremos mais detalhadamente adiante como: a efetividade ${ }^{2}$ do uso dos medicamentos, a segurança ${ }^{3}$ e o crescente aumento de custo que os mesmos passam a representar no orçamento do sistema social.

Como explicam TOGNONI e LAPORTE (1989), o medicamento adquire um novo conceito a partir das décadas de 50 e 60 . A avaliação de seu papel nas comunidades exige a adoção de critérios como eficácia, segurança e custo, para definir a eficiência global ${ }^{4}$ no uso de um determinado medicamento. CASTRO e col. (2000), concluem que "o medicamento passa a ser um 'elemento problemático' e não apenas um agente terapêutico, com a finalidade de tratamento, prevenção e diagnóstico". TOGNONI e LAPORTE (1989) fazem a seguinte constatação:

É difícil quantificar a contribuição - positiva ou negativa - dos medicamentos a saúde das comunidades. Esta depende de tantos fatores mais importantes, como a nutrição, as condições de moradia, as condições de trabalho, a educação, os hábitos sociais, etc (...), que, ao exame das cifras estatísticas gerais (por ex. a mortalidade), qualquer efeito que se deva ter os medicamentos deve ficar necessariamente diluído e, em conseqüência, não identificados.

ROZENFELD (1989a), destaca que os estudos mundiais sobre utilização dos medicamentos demonstram uma série de distorções comuns à maioria dos países: abundância de produtos desnecessários ou com

\footnotetext{
2 LAST (1989, apud LAPORTE, 1993) define como "o grau em que determinada intervenção, procedimento, regime ou serviço postos em prática obtêm que se pretende alcançar para determinada população". Este aspecto será objeto de discussão na seção 1.2.2.

${ }^{3} \mathrm{~A}$ segurança na utilização dos medicamentos está intimamente relacionada às reações adversas a medicamentos (RAM). Segundo a ANVISA (2003), RAM "é qualquer resposta a um medicamento que seja prejudicial, não intencional, e que ocorra nas doses normalmente utilizadas em seres humanos para profilaxia, diagnóstico e tratamento de doenças, ou para a modificação de uma função fisiológica". Fatos históricos como o caso do dietilenoglicol e da talidomida, foram fomentadores para que as RAM's começassem a ser sistematicamente abordadas. A segurança também será objeto de discussão na seção 1.2.2.

${ }^{4}$ Utiliza-se o conceito de LAST (1989, apud LAPORTE, 1993) para eficácia e eficiência. O primeiro como o "grau em que determinada intervenção, procedimento, regime ou serviço produzem um resultado benéfico em condições ideais" e o segundo como "o grau em que os recursos empregados para realizar determinada intervenção, procedimento, regime ou serviço, de eficácia e efetividade são mínimos". Igualmente objetos de discussão na seção 1.2.2.
} 
potencial tóxico inaceitável; prescrições irracionais; automedicação (quimização), etc. Segundo a autora, estes desvios são resultados, em última instância, do caráter lucrativo da atividade industrial na produção de medicamentos, afetando condutas na área de ensino, prescrição e consumo.

A reboque das questões que emergem com o novo papel do "medicamento" no panorama mundial e com a conseqüente preocupação com o acesso e uso correto (ou racional) dos medicamentos, principalmente no caso das populações mais carentes, surge uma discussão não só entre as comunidades acadêmicas, mas também entre diversos organismos mundiais e entidades relacionadas: o "uso racional dos medicamentos". Resultante dessa discussão, surgem algumas ações políticas propositoras de formas de gestão e de políticas para lograr o uso racional dos medicamentos.

\subsection{PRINCIPAIS QUESTÕES SOBRE O USO RACIONAL DE MEDICAMENTOS}

As questões centrais no debate sobre 0 uso racional de medicamentos podem ser sistematizadas em dois blocos:

1. O acesso aos medicamentos e

2. O uso correto dos medicamentos.

A primeira questão refere-se à falta de acesso, a qual grande parcela da população global sofre, em contradição com a franca expansão do mercado mundial de medicamentos. A segunda questão faz alusão ao uso indiscriminado (que será chamado de irracional) por parte da população que tem acesso aos medicamentos. Cada uma destas questões será discutida, respectivamente, nas duas próximas subseções. 


\subsubsection{Acesso aos Medicamentos}

O acesso aos medicamentos, mesmo os essenciais, ainda é um problema mundialmente reconhecido no campo sanitário (SOBRAVIME, 2001).

O mercado farmacêutico global encontra-se em expansão há vários anos de maneira continuada, sendo a taxa média de crescimento global da ordem de 7 a 8\% ao ano (MACHADO-DOS-SANTOS, 2001). De acordo com a IMS Health (apud farmácia.com.pt, 2007 a/b), o tamanho deste mercado foi estimado em aproximadamente 643 bilhões de dólares para o ano de 2006, com uma projeção de mais de um trilhão de dólares para 2020.

Embora seja um mercado de grande porte e em constante crescimento, sua distribuição está longe de ser equânime ${ }^{5}$. Estimativas, da Organização Mundial de Saúde e de entidades ligadas à indústria farmacêutica, bem como de outras instituições debatedoras do tema, demonstram o caráter desigual dessa distribuição:

- O crescimento deste mercado é potencialmente nos países desenvolvidos (IMS Health apud farmácia.com.pt, 2007a);

- Nos países em desenvolvimento, além do crescimento ser menor sua progressão não foi acompanhada por um número proporcional em unidades, o que significa que se deu fundamentalmente em função do aumento de preços praticados (MACHADO-DOSSANTOS, 2001);

\footnotetext{
${ }^{5}$ Para efeito deste trabalho, está implícito o conceito de eqüidade encontrado em PORTO (1997) apoiado em LE GRAND (1982), ARTELLS e MOONEY (1983) e TUNER (1986), na qual a eqüidade na área de saúde é um princípio que rege funções distributivas, com objetivo de compensar ou superar as desigualdades existentes, consideradas socialmente injustas. Para a autora, portanto, sob ponto de vista teleológico, eqüidade e igualdade são sinônimos. Não existem propostas eqüitativas que tenham por objetivo final o alcance de maiores desigualdades.
} 
- O maior peso no crescimento do mercado de 2006 (62\% deste crescimento) deve-se a produtos com fins mais específicos. Em 2000 , este mesmo grupo contribuiu apenas com 35\% do crescimento do mercado global (IMS Health apud farmácia.com.pt, 2007a);

- A previsão para 2020 baseia-se mais no fato do crescimento da camada de população idosa e cada vez mais sedentária, especialmente nos novos mercados de países em desenvolvimento, do que em aspectos que afetam populações mais carentes ou o que possam ocorrer nos países em desenvolvimento (IMS Health apud farmácia.com.pt, 2007b);

- A OMS estima que um terço da população mundial não tem acesso aos medicamentos essenciais (SOBRAVIME, 2001 e MACHADO-DOS-SANTOS, 2001);

- A OMS também estima que, em alguns países da África e da Ásia, aproximadamente $50 \%$ da população ainda carece de medicamentos essenciais (SOBRAVIME, 2001).

No Brasil, um estudo demonstrou que, quando o mercado farmacêutico é estratificado em função da renda da população, a distribuição se torna ainda mais desigual. Os dados de 1999 da ABIFARMA (apud MACHADO-DOS-SANTOS, 2001) mostram que $48 \%$ do consumo de medicamentos está nas mãos de $15 \%$ da população, cuja renda é maior que dez salários mínimos, enquanto $51 \%$ da população que corresponde a uma renda menor que dois salários-mínimos consome $16 \%$ dos medicamentos ${ }^{6}$. Como bem lembrado por MACHADO-DOS-SANTOS (2001), os números da

\footnotetext{
${ }^{6}$ Esta informação foi publicada na revista do Conselho Regional de Farmácia de São Paulo "Fracionamento: medicamentos da dose exata", São Paulo: Revista do Farmacêutico no 26, junho/julho de 2005.
} 
tabela abaixo sofrem algum reparo em função das políticas públicas de distribuição de medicamentos implementadas pelo poder público. Isto, porém, não compensa a desigualdade demonstrada pela informação.

Tabela 1 - Perfil do consumo brasileiro de medicamentos, segundo a faixa de renda da população, Brasil, 2001.

\begin{tabular}{ccc}
\hline População & Renda & Consumo \\
\hline $15 \%$ & $\mathrm{R}>10 \mathrm{SM}^{*}$ & $48 \%$ \\
$34 \%$ & $4<\mathrm{R}<10 \mathrm{SM}$ & $36 \%$ \\
$51 \%$ & $\mathrm{R}<2 \mathrm{SM}$ & $16 \%$ \\
\hline${ }^{*} \mathrm{SM}=$ Salário Mínimo &
\end{tabular}

Extraído de: ABIFARMA, 1999 (apud COHEN, 2000, apud MACHADO-DOSSANTOS, 2001)

\subsubsection{Uso Correto dos Medicamentos}

Se por um lado, grande parte da população não tem acesso aos medicamentos, por outro, o debate sobre o URM revela a utilização, muitas vezes indiscriminada, daqueles que possuem acesso aos medicamentos, o que chamaremos de irracional.

Inicialmente, é relevante estabelecer o papel-chave do medicamento, que praticamente "sustenta" a cultura terapêutica médica. GARCIA (1994), descreve:

Os medicamentos constituem o procedimento terapêutico mais massivamente utilizado pelos médicos. Prescrever, dispensar, medicar ou simplesmente indicar converteu-se em práticas sociais freqüentes e "naturais" não só para os profissionais de saúde, mas também para a população. Custoso e perigoso, o consumo irracional de medicamentos é um fenômeno que se multiplica com rapidez em todo mundo.

CORDEIRO (1980), baseado em diversos estudos, afirma que cerca de $80 \%$ das consultas médicas implicam na prescrição de um ou mais medicamentos. 
Um aspecto importante é o estabelecimento histórico do medicamento como a primeira opção de escolha na decisão terapêutica (ou do tratamento) médica. Isso, por si só, representa um grande impacto, pois o medicamento assume função central na conduta médica, relegando outras possíveis formas de tratamento a segundo plano.

Outro aspecto é o processo de utilização dos medicamentos nesse cenário em que ele se estabelece como terapia hegemônica. A discussão desse processo, no debate do URM, está vinculado a quatro critérios técnicos que serão conceituados na próxima subseção: eficácia, efetividade, eficiência e segurança. Para conceituar eficácia, efetividade e eficiência, este trabalho adotará as definições de LAST (1989, apud LAPORTE, 1993). Para a segurança, que tem íntima relação com a reação adversa ao medicamento (RAM), adotaremos o conceito desenvolvido pela Sociedade Brasileira de Vigilância de Medicamentos (SOBRAVIME, 2001) e o conceito de RAM definido pela Agência Nacional de Vigilância Sanitária (ANVISA, 2003).

\subsubsection{Definições e Questões Sobre os Critérios para o Uso Correto dos Medicamentos: Eficácia, Efetividade, Eficiência e Segurança}

Eficácia é o grau no qual determinada intervenção, procedimento, regime ou serviço produz um resultado benéfico em condições ideais (LAST 1989, apud LAPORTE, 1993). Em termos de farmacologia clínica poderíamos dizer, de forma simplificada, se realmente o medicamento está produzindo o efeito terapêutico desejado (ou proposto). Por exemplo, se um analgésico realmente alivia a dor.

Então, o uso correto dos medicamentos parte de uma premissa aparentemente óbvia: "o medicamento é eficaz?". No campo prático, esta pergunta tem se demonstrado passível de ser posta em questão. Se não for eficaz, além do usuário não estar combatendo a doença diagnosticada, 
ainda corre o risco de ter uma reação adversa a este "medicamento". Alguns dados servem para ilustrar que, na realidade recente, ainda existem no mercado medicamentos de eficácia duvidosa ou pouco comprovada.

Segundo LAPORTE (1993), o diretor geral da OMS declarou, em 1991, que se gastam nos países em desenvolvimento, pelo menos um bilhão de dólares por ano em antidiarréicos, antitusígenos e expectorantes de eficácia não comprovada para o tratamento de enfermidades diarréicas e infecções respiratórias, quadros que são causa de 7,5 milhões de falecimentos infantis nesses países.

Um dos aspectos que interferem na eficácia são as associações medicamentosas, ou seja, a formulação de dois ou mais fármacos na mesma especialidade farmacêutica. Muitas dessas associações são irracionais como, por exemplo, alguns xaropes que contêm, na mesma formulação, um fármaco que suprime e outro que estimula a tosse (SOBRAVIME, 2001). Muitas vezes, nessas associações, um ou mais fármacos não possuem eficácia comprovada.

ROZENFELD (1989a) alerta que "alguns estudos sobre o perfil dos produtos oferecidos ao consumidor mostram distorções sobejamente já conhecidas: altos percentuais de combinações de doses fixas - 69,2\% para os antimicrobianos e $73,2 \%$ para os produtos de combate a tosse - e excesso de substâncias ativas de eficácia insuficientemente comprovadas".

Outra consideração é a via de administração como determinante para a eficácia. Muitas vezes um medicamento pode ser eficaz por uma via de administração, mas por outra não. Na revisão de registros de medicamentos feita pela DIMED/SNVS, entre 1985 e 1987, detectou-se 45 especialidades farmacêuticas registradas para uso pela via oral que possuíam alguma substância inócua por esta via. Na ocasião, a manutenção do registro foi condicionada à retirada da substância da formulação (ROZENFELD, 1989a).

Baseada na necessidade de comprovar a eficácia dos medicamentos, a farmacologia clínica iniciou, a partir dos anos 50, seus métodos de avaliação com ensaios clínicos controlados (ECC) (CASTRO, 2000), 
basicamente, ensaios experimentais com grupos aleatórios selecionados em uma determinada população.

Efetividade é o grau em que determinada intervenção, procedimento, regime ou serviço posto em prática obtém em relação ao que se pretende alcançar para uma determinada população (LAST 1989, apud LAPORTE, 1993). Em termos de farmacoterapêutica, significa verificar - após comprovada a eficácia de um medicamento (através dos ECC's) - qual é o grau de resultado positivo ao colocar o produto em uso. A efetividade depende de uma série de fatores culturais e comerciais, incluindo acesso ao medicamento, as condições de armazenagem, o grau de qualificação dos profissionais prescritores e dispensadores e a adesão do paciente à terapia.

Assim, não basta o medicamento ser eficaz, ele deve ser utilizado de forma que sua eficácia possa ser efetiva.

Os fatores culturais e comerciais são determinantes para o URM e a forma como se constituem é objeto de críticas na discussão sobre o URM. O grau de qualificação dos profissionais prescritores, por exemplo. É fator decisivo e reflete em uma prescrição médica racional ${ }^{7}$, aspecto inerente à consulta médica. Porém, a prática médica habitual demonstra que as prescrições médicas ocorrem como "prescrição por reflexo espinhal"8 (LAPORTE, 1989). Poucos cursos de graduação de medicina, sobretudo nos países em desenvolvimento, possuem disciplinas específicas sobre farmacologia clínica e terapêutica, que capacitariam o corpo médico a uma melhor avaliação da prescrição (SOBRAVIME, 2001). A prescrição fica vulnerável e influenciada por vários fatores, sobretudo pela propaganda

7 Prescrição médica racional de acordo com a definição estabelecida em Nairobi, encontrado na seção 1.3.2 deste capítulo.

${ }^{8}$ Reflexo espinhal é uma maneira coloquial de se referir aos reflexos medulares; isto é, àqueles que ocorrem ao nível da medula espinhal. Estes reflexos são respostas motoras desencadeadas pela medula espinhal e não pelo cérebro. GUYTON (1989), em seu "Tratado de fisiologia médica" explica as diferentes formas de reflexos medulares, como o reflexo de estiramento (responsável pela contração reflexa de um músculo quando estirado), o reflexo flexor (contração de músculos devido a estímulos sensoriais na pele, afastando o membro do estímulo: um chama, por exemplo), entre outros. Certamente LAPORTE estabelece uma metáfora na qual os médicos não prescrevem em função de critérios lógicos estabelecidos pelo URM (ou como um ato pensado), mas em função de précondicionamentos estabelecidos. Estes pré-condicionamentos têm íntima relação com a propaganda médica pela indústria farmacêutica, o que será discutido adiante. 
médica, promovida pela indústria farmacêutica (assunto abordado em seções e capítulos posteriores). Estudos demonstram que prescrições médicas possuem erros na dosagem, problemas com interações medicamentosas e de poli-farmácia (muitos medicamentos receitados em conjunto). WANNMACHER (2005), no artigo "Erros, evitar o evitável", publicado pela Organização Pan Americana de Saúde, reúne nove estudos (do Brasil e do mundo) que demonstram os problemas de erros com prescrições. Um deles concluiu que mais de 98 mil pessoas morreram no EUA por erros médicos. Outro, analisando mais de 250 mil receitas, apresentou como resultado 13 erros a cada 100 prescrições.

A dispensação ${ }^{9}$ é uma atividade que complementa a prescrição médica e tem papel crucial neste processo. Assim como os prescritores, os dispensadores sofrem com falta de capacitação na graduação e de capacitação continuada na vida profissional (SOBRAVIME, 2001). Apesar disso, um estudo de revisão sobre a intervenção do farmacêutico no uso de medicamentos por pacientes idosos (ROMANO-LIEBER e col., 2002) concluiu que "de uma forma geral, as intervenções mostraram resultados positivos, reduzindo custos, melhorando as prescrições, promovendo maior adesão do paciente ao tratamento e controlando a possibilidade de reações adversas". O problema é que, apesar da exigência legal (Lei 5.991/73) da presença do farmacêutico responsável em todo o período de funcionamento de farmácias e drogarias, na prática, a maioria destes estabelecimentos funcionam impunemente sem cumprir esta exigência (SILVA, 2002).

A reboque da ausência do farmacêutico nas farmácias e drogarias, instalou-se outro fenômeno digno de ser lembrado: a "empurroterapia" (ROZENFELD, 1989a), isto é, a prática de balconistas de farmácias e

\footnotetext{
${ }^{9}$ Dispensação é o ato profissional farmacêutico de proporcionar um ou mais medicamentos a um paciente, geralmente como resposta a apresentação de uma receita elaborada por um profissional autorizado. Neste ato o farmacêutico informa e orienta o paciente sobre o uso adequado do medicamento. São elementos importantes da orientação: a ênfase no cumprimento da dosagem, a influência dos alimentos, a interação com outros medicamentos, o reconhecimento de reações adversas potenciais e as condições de conservação dos produtos. Definição na Portaria no 3.916/MS/GM, de 30 de outubro de 1998.
} 
drogarias, de indicar (ou "empurrar") medicamentos ao paciente por motivos que lhes convêm comercialmente.

Outro fenômeno que interfere na efetividade é a automedicação decisão do usuário que decide como e quanto fármaco tomar - utilizando-se dos medicamentos selecionados entre todos os oferecidos pelo médico ou por diferentes profissionais de saúde (normalmente não coordenados) e até pelos vizinhos (TOGNONI e LAPORTE, 1989). Um estudo sobre automedicação no Brasil (ARRAIS e col., 1997) identificou que "a escolha de medicamentos é baseada, principalmente, na recomendação de pessoas leigas $(51,0 \%)$, sendo também relevante a influência de prescrições anteriores (40,0\%)".

Tanto a prescrição quanto a dispensação, a empurroterapia ou a automedicação, são práticas que pioram na medida em que são feitas sem a correta informação técnica e ficam a mercê de influências comerciais, independente do mérito destas ações.

Eficiência é o grau em que os recursos empregados para realizar determinada intervenção, procedimento, regime ou serviço, de eficácia e efetividade são mínimos (LAST 1989, apud LAPORTE, 1993). Basicamente é um conceito que inclui o fator custo na qualidade de assistência à saúde. $A$ farmacoeconomia é uma especialidade que nasce nesse bojo, orientada a melhorar a eficiência dos serviços de saúde. De acordo com a OMS (2007), estima-se que os custos com medicamentos representam de 10 a $40 \%$ do custo sanitário total, por isso a importância deste aspecto na discussão do URM.

Segurança é grau de freqüência ou gravidade de reação adversa ao medicamento (RAM) por ele produzido (SOBRAVIME, 2001). RAM, por sua vez, é "qualquer resposta a um medicamento que seja prejudicial, não intencional, e que ocorra nas doses normalmente utilizadas em seres humanos para profilaxia, diagnóstico e tratamento de doenças, ou para a modificação de uma função fisiológica" (ANVISA, 2003). Assim um medicamento é tão mais seguro na medida em que apresente menos reações adversas, tanto em freqüência quanto em gravidade. 
Como a questão da segurança tem aspectos muito relevantes no debate do URM, trataremos deste tema na próxima subseção.

\subsubsection{Segurança / Reações Adversas}

A segurança na utilização dos medicamentos está intimamente relacionada às reações adversas a medicamentos (RAM). As RAM's existem desde os primeiros medicamentos. Como ensina ROZENFELD (1997, apud NASCIMENTO, 2003), todo medicamento tem um potencial de risco e as reações adversas multiplicam-se com o consumo indiscriminado. Paracelso (1493 - 1541) já afirmava que "todas as substâncias são venenos, não existe nenhuma que não seja. A dose correta diferencia o veneno do remédio". Porém, a atenção formal com aspectos de segurança é relativamente recente. Os primeiros relatos formais sobre reações adversas a medicamentos foram registrados, no fim do século XIX, a respeito de mortes súbitas com o uso de clorofórmio (SOBRAVIME, 2001).

Dois fatos trágicos foram marcantes para que o perfil de segurança começasse a ser considerado como condição essencial na escolha do medicamento.

O primeiro, em 1937, quando foram registradas mortes de dezenas de crianças nos Estados Unidos pelo uso do xarope sulfonilamida. Importante notar que o agente causador destas mortes não foi o fármaco (ou o princípio ativo) do produto, e sim um excipiente ${ }^{10}$ deste xarope, o etilenoglicol (CASTRO e col., 2000).

\footnotetext{
${ }^{10}$ Fármaco é a substância química que é o princípio ativo do medicamento (Portaria no 3.916/MS/GM, de 30 de outubro de 1998); Princípio ativo é uma substância ou mistura de substâncias afins dotadas de um efeito farmacológico específico ou que, sem possuir atividade, adquire um efeito ao ser administrada no organismo, como é o caso dos profármacos; Excipiente é a substância farmacêutica auxiliar que do ponto de vista farmacológico é inativa e permite que o princípio ativo tenha uma determinada forma farmacêutica (os dois últimos, de acordo com a Resolução - RDC № 157, de 31 de maio de 2002).
} 
O segundo fato ocorreu entre 1958 e 1962, em função do uso do medicamento talidomida por mulheres gestantes. Observou-se, principalmente na Alemanha e na Inglaterra, o nascimento de milhares de crianças que apresentavam graves deformidades congênitas ${ }^{11}$, caracterizadas pelo encurtamento dos ossos longos dos membros superiores e/ou inferiores, com ausência total ou parcial das mãos, pés e/ou dos dedos. Em cerca de $25 \%$ dos casos, verificou-se o acometimento simultâneo e assimétrico dos quatro membros, conformando um quadro convencionado de focomelia (ou forma de foca). Estima-se que entre 10 a 15 mil crianças nasceram com malformação. Lenz, médico alemão que vinha acompanhando uma série de casos da nova síndrome, estabeleceu, pela primeira vez, a correlação entre o consumo da talidomida por gestantes e o aparecimento das malformações congênitas (OLIVEIRA e col.,1999).

Outros fatos também ocorreram com o uso de proctolol e zomepirac (DUKES, 1979 e SHAPIRO, 1984 apud CAMARGO, ZANINI \& CIOLASANCHES, 1991).

Devido a estes acontecimentos, a farmacologia clínica iniciou seus métodos de avaliação com ensaios clínicos controlados a partir dos anos 50 (CASTRO e col., 2000), caracterizados, basicamente, por ensaios experimentais com grupos aleatórios selecionados de determinada população. Embora estes ensaios sejam métodos adequados para verificar a eficácia (TOGNONI e LAPORTE, 1993), é necessário lembrar as limitações do método (principalmente na questão da segurança), baseado no fato deste tipo de ensaio estar restrito a certos grupos de pacientes. Normalmente, por impedimentos éticos, grupos populacionais como crianças, mulheres grávidas e idosos não participam destes estudos.

A segurança também se revela como aspecto de grande importância no uso correto dos medicamentos quando olhamos para os números relativos a intoxicações. Os dados do Centro de Assistência Toxicológica do

\footnotetext{
${ }^{11}$ Congênito é aquilo que é gerado ao mesmo tempo, nascido com o indivíduo, conatural, conato, inato. Novo dicionário Aurélio de Língua Portuguesa, 3ª ed., Curitiba: Positivo, 2004.
} 
Hospital das Clínicas da Universidade de São Paulo (CEATOX) mostram que, em 1996, o medicamento alcançou primeiro lugar como substância mais reportada ao CEATOX, com $45,8 \%$ das intoxicações registradas, seguido dos sanitários domésticos com 17\%. Dados do Sistema Nacional de Informações Tóxico-Farmacológicas (SINITOX) de 2005, também colocam o medicamento no topo da lista de intoxicação por produtos com $26 \%$ dos casos registrados. Nessa listagem, os agrotóxicos ficam em segundo lugar com 7\%. A diferença entre os dados do CEATOX e o SINITOX é provavelmente porque o primeiro utiliza, basicamente, dados da grande São Paulo e o segundo, de todo Brasil. De qualquer forma, ambos indicam o medicamento como produto que mais intoxica a população, certamente devido a utilização de forma totalmente inadequada.

Dado o impacto direto desta questão na saúde da população, a segurança é um dos aspectos mais preocupantes na discussão do uso racional de medicamentos.

1.2.2.3 Fatores que Influenciam os Critérios para o Uso Correto dos Medicamentos

Devido ao contexto de modelo econômico no qual o uso de medicamentos está inserido, os quatro critérios técnicos descritos são fortemente influenciados por uma série de fatores, dentre os quais a grande quantidade de lançamentos de novos produtos e a forte propaganda médica movida pela indústria farmacêutica.

A busca pela competição coloca novos medicamentos no mercado que, de acordo com as informações abordadas nesse trabalho, nem sempre possuem relevantes vantagens se comparados aos já existentes: eficácia clínica superior, vantagem na forma de uso (maior efetividade), melhor relação custo/benefício (maior eficiência) ou ainda maior segurança. 
$\mathrm{Na}$ esteira da competitividade, estes novos produtos, embora muitas vezes não apresentem vantagem, são fortemente propagados pela indústria como inovadores.

Dessa forma, as duas próximas subseções foram destacadas para estes assuntos: a primeira para discutir os lançamentos dos novos produtos, incluindo o que pode ser considerado "novo" e a segunda sobre a propaganda médica.

\subsection{Lançamento de Novos Produtos Pela Indústria Farmacêutica e a Grande Quantidade de "Diferentes Medicamentos" no Mercado}

Como dito no início deste capítulo, com o advento da indústria farmacêutica, nos anos 40, a partir das décadas de 50 e 60, a curva de registros de patentes passa a ser logarítmica. Essa avalanche de novos produtos trouxe consigo, necessariamente, um grande número de informações técnicas no âmbito da farmácia e da medicina e também a necessidade da indústria farmacêutica concorrer, de forma mais aguda, com seus produtos no mercado.

Diversos estudos demonstram que os lançamentos no mercado dos ditos "novos produtos" não apresentam efetivos ganhos terapêuticos e normalmente trazem alterações superficiais.

O primeiro aspecto a se considerar é a complexidade da definição de "produto novo" nessa indústria. MACHADO-DOS-SANTOS (2001) explica um pouco sobre esta complexidade:

A definição exata do que seja um produto novo nessa indústria é complexa, existindo várias possibilidades, que variam desde um produto químico-terapêutico novo até meras modificações nas suas formas de apresentação ou dosagem. Mais ainda, quando se fala de inovações como uma questão estratégica de competição, faz-se necessário considerar a dinâmica desse processo. Deve-se ter em conta o fato de que muitas drogas apresentadas como novas representavam e/ou representam, na verdade, 
mera continuidade de produtos anteriormente existentes, que passaram por modificações secundárias.

O segundo aspecto é que, face à realidade demonstrada em alguns estudos, os lançamentos, de fato, não têm sido produtos efetivamente novos ou com inovação terapêutica.

ANGELL (2004) explica que a agência reguladora de alimentos e medicamentos nos Estados Unidos, Food and Drug Administration (FDA) possui duas formas de classificar os fármacos. A primeira é sob a perspectiva da molécula, chamada de "tipo químico". Nessa classificação é verificada se a molécula já existe no mercado sob alguma forma; neste caso - FDA a classifica como derivado químico, nova formulação ou como combinação de molécula conhecida. Se, no entanto, a molécula for considerada realmente nova, o FDA a classifica como "nova entidade molecular" (NME, em inglês). A segunda forma de classificar a molécula é de acordo com o benefício sobre os fármacos existentes no mercado para um tratamento nas mesmas condições. Se o benefício for maior, o FDA a classifica como "prioritária", utilizando-se a letra P (de priority); se for menor, é classificada como "padrão", utilizando-se a letra S (de standard). Dizer que um fármaco é necessariamente novo, deve ser baseado na conjunção dessas duas classificações. Uma nova entidade molecular não traz, necessariamente, um benefício sobre os tratamentos já existentes. Assim como também moléculas que sofreram pequenas modificações podem ou não representar benefícios sobre esses mesmos tratamentos.

Com base nesses critérios, ANGELL (2004) fez um levantamento, entre 1998 a 2002, com os dados dos novos medicamentos aprovados pelo FDA. Desses 415 novos medicamentos (média de 83 por ano), 133 (32\%) eram novas entidades moleculares (NME). Destas 133 NME's, apenas 58 (12 por ano) foram consideradas como fármacos "P", ou seja, que traziam maiores benefícios que os já existentes no mercado. Ou seja, 14\% daquilo que foi registrado como medicamento novo no FDA era, de fato, uma inovação. 
De acordo com BERMUDEZ (1992) "nas décadas de 50 e 60 foram colocados no mercado uma média de 444 novos produtos a cada ano, dos quais $10 \%$ foram considerados verdadeiramente novas substâncias".

Outro estudo, realizado na França, sobre 508 novos produtos farmacêuticos lançados no mercado entre 1975 a 1984, verificou em 70\% a ausência de vantagens terapêuticas ${ }^{12}$. Uma avaliação pela Food and Drug Administration (FDA), realizada em 348 novos medicamentos das 25 maiores empresas farmacêuticas estadunidenses, comercializados no período de 1981-1988, considerou que apenas 3\% (12 medicamentos) representavam importantes contribuições relativas aos tratamentos já existentes (SOBRAVIME, 2001).

A começar pela confusão gerada pelo entendimento sobre "novo produto" no mercado, passando pelo crescente número desses "novos produtos" e culminando nos estudos que indicam sua "irracionalidade" do ponto de vista sanitário, podemos inferir que o lançamento de "novos produtos" atende prioritariamente a critérios comerciais a despeito das necessidades sanitárias da população. Não obstante a esta constatação, que por si já nos parece bastante preocupante, a introdução de um número cada vez maior de produtos no mercado gera forte concorrência entre marcas de produtos (muitas vezes idênticos) que irá desembocar na questão da propaganda de medicamentos, tema abordado na próxima subseção.

\subsection{Propaganda de Medicamentos}

A promoção de medicamentos é um processo complexo, envolvendo o convencimento de prescritores, dispensadores e pacientes sobre as vantagens do produto através da divulgação de resultados dos estudos relacionados ao seu desenvolvimento, objetivando sua conseqüente

\footnotetext{
${ }^{12}$ Vantagens terapêuticas entendidas como vantagens de um determinado medicamento em relação aos critérios de eficácia, eficiência, efetividade e segurança descritas na seção anterior.
} 
comercialização. Conforme a própria definição, a publicidade influencia o julgamento de usuários e prescritores sobre os medicamentos. Vários estudos demonstram o emprego da propaganda como fonte de informação pelos prescritores, sendo considerada determinante na prescrição (BRASIL, 2005).

Segundo BERMUDEZ (1995), o desenvolvimento de novos produtos levou as décadas de 50 e 60 a se destacarem pelas mudanças nas estratégias de marketing das empresas transnacionais, com o objetivo de influenciar nas prescrições médicas.

Para se ter uma idéia da dimensão representada pelo investimento em marketing, observe os dados abaixo publicados no site Center for Public Integrity (2005). Mais de um terço dos recursos da indústria farmacêutica é dirigido para o setor de marketing e estima-se que em torno de US\$ 60 bilhões de dólares são gastos anualmente com o marketing farmacêutico. Esses números são mais significativos quando comparados aos gastos despendidos com pesquisa e desenvolvimento.

Tabela 2 - Comparativo entre os gastos com marketing e pesquisa e desenvolvimento das 11 maiores indústrias farmacêuticas, 2005.

\begin{tabular}{lcc}
\hline \multicolumn{1}{c}{ EMPRESA } & $\begin{array}{c}\text { CUSTOS COM } \\
\text { MARKETING* }\end{array}$ & $\begin{array}{c}\text { PESQUISA E } \\
\text { DESENVOLVIMENTO* }\end{array}$ \\
\hline Pfizer & 16,90 & 7,68 \\
GlaxoSmithKline & 12,93 & 5,20 \\
Sanofi-Aventis & 5,59 & 9,26 \\
Johnson \& Johnson & 15,8 & 5,20 \\
Merck & 7,35 & 4,01 \\
Novartis & 8,87 & 4,21 \\
AstraZeneca & 7,84 & 3,80 \\
Hoffman La Roche & 7,24 & 4,01 \\
Bristol-Meyers-Squibb & 6,43 & 2,50 \\
Wyeth & 5,80 & 2,46 \\
Abbott Labs & 4,92 & 1,70 \\
\hline
\end{tabular}

*Em bilhões de dólares

Extraído de: THE CENTER FOR PUBLIC INTEGRITY. Drug lobby second to none. [relatório na Internet] 2005 [acesso em 27 julho 2005] Disponível em http://www.publicintegrity.org/Content.aspx?src=search\&context=article\&id=723 
BERMUDEZ (1992), utilizando-se de dados de 1985, critica o contraste entre a orientação da RENAME de que cerca de 400 produtos seriam suficientes para suprir a maioria das necessidades brasileiras e a estimativa, na época, de mais de 40 mil especialidades registradas no país, com aproximadamente $13 \mathrm{mil}$ dessas em circulação no mercado farmacêutico brasileiro. BERMUDEZ (1992) acrescenta que "esta intensa competição por marcas no mercado acaba levando a intensos lobbies da indústria junto aos profissionais de saúde e estabelecimentos que lidam com a venda de medicamentos". O autor salienta ainda que "é importante assinalar que se estima que mais de $40 \%$ das marcas registradas em uso em todo o mundo se referem a produtos farmacêuticos e que a promoção do nome comercial consome entre 20 e $40 \%$ do faturamento das empresas multinacionais".

Os intensos lobbies previstos por BERMUDEZ (1992) são extraordinariamente grandes. Segundo o site The Center for Public Integrity (2005), a Indústria Farmacêutica, nos EUA, gastou em torno de US\$800 milhões de dólares em lobby, em diversos níveis públicos entre 1998 e 2004, para influenciar as modificações das políticas públicas que afetam o setor. É o maior gasto com lobby nos EUA, e conseqüentemente, no mundo.

FEFER (1999) demonstra como o marketing enxerga a tendência de mercado e qual o impacto no URM. De forma resumida, o autor enumera o seguinte:

- O mercado farmacêutico seguirá crescendo devido a fatores como envelhecimento da população, urbanização, atitudes, comportamentos, etc;

- Paradoxalmente, neste mercado em constante crescimento, as empresas capazes de realizar a P\&D diminuem. As fusões, aquisições e joint-ventures têm como resultado a formação de mega empresas para dar conta da infra-estrutura e dos recursos que representam a $P \& D$; 
- Como impacto social à parte, este processo de consolidação eliminará muitos cargos (exemplificando, temos o caso da Novartis, que terá menos 10.000 funcionários do que as empresas que a formaram);

- As empresas reconhecem que terão que desenvolver novos fármacos, pois está chegando o período de caducidade de muitas patentes. Principalmente com as políticas de redução de preço (como os medicamentos genéricos), os medicamentos com patentes vencidas sofrerão rápida redução de preços.

FEFER (1999) conclui, então, que, devido a estes fatores, os medicamentos serão muitos custosos e "haverá grandes pressões para seu uso, já que as empresas terão que recuperar seus custos para poder continuar suas atividades de P\&D. Por isso é fundamental educar e informar os médicos sobre a relação de custo/benefício entre as distintas alternativas terapêuticas, já que sabemos que nem sempre o mais novo significa o melhor".

De acordo com SANTI (1999), a indústria farmacêutica faz um trabalho de veiculação de produtos, marcas e conceitos em praticamente todos os níveis. Diretamente nas farmácias e drogarias, nas redes de televisão, nas rádios, mas sobretudo em consultórios médicos e hospitais. Destacamos aqui a questão da veiculação de "conceitos", que será alvo de discussão nos capítulos posteriores.

O mais preocupante na discussão do URM e indicado pelos estudos existentes é que, na esteira da disputa comercial, a qualidade desta propaganda acaba por assumir um papel mais desorientador do que informativo. "Personalidades ligadas a FDA dos Estados Unidos afirmaram, nos fins dos anos oitenta e início dos anos noventa, que 'a maioria dos materiais promocionais apresentados à agência para serem avaliados são falsos e/ou desorientadores'... e a promoção de medicamentos nos Estados 
Unidos reflete um desinteresse pelo bem estar público" (SOBRAVIME, 2001).

Dada a preocupação com o impacto da promoção dos medicamentos no uso racional de medicamentos, a OMS publica, em 1998, através da sua resolução WHA 41.17, um manual de "critérios éticos para a promoção de medicamentos". Este manual é um "pacote" de princípios congregando desde a questão de representantes de vendas, distribuição de amostras grátis e participação em congressos científicos, à informação ao paciente, entre outras recomendações. No manual, sua intenção está claramente descrita no item objetivo: "contribuir para o uso racional de medicamentos".

Desde o ano de 2002, a Agência Nacional de Vigilância Sanitária (ANVISA) desenvolve, em parceria com instituições de ensino superior brasileiras, o Projeto de Monitoração de Propaganda. Na primeira fase do projeto (2002 a 2003), a ANVISA recebeu 4.485 propagandas das quais $51 \%$ foram autuadas sob a luz da RDC 102/2000 (que regulamenta a propaganda de medicamentos no Brasil). A não autuação das $49 \%$ restantes deve-se, em parte, a autuações anteriores. Dentre os motivos das autuações, havia grande número de produtos comercializados sem registro, propagandas que não mencionavam a contra-indicação principal, textos que sugeriam ausência de efeitos colaterais e comparações sem embasamento científico (ANVISA, 2008).

Para finalizar, gostaríamos de concluir com a observação de LEXCHIN (1997) que "Para se compreender as atividades da indústria (...) é necessário considerar um fato fundamental: a indústria é impelida pela busca de lucros". 


\subsection{ALGUMAS AÇÕES POLÍTICAS RELACIONADAS AO URM}

\subsubsection{Lista de Medicamentos Essenciais}

Um marco fundamental para a nova política de medicamentos é a $28^{\mathrm{a}}$ Assembléia Mundial de Saúde (OMS), realizada em 1975. Nesta assembléia, o diretor geral da OMS apresentou um informe que examinava os problemas dos países em desenvolvimento relacionados a medicamentos com finalidade de ampliar o acesso e o uso racional às populações cujas necessidades não eram atendidas pelos sistemas de saúde. Foi dado destaque aos critérios de seleção desses medicamentos essenciais, revisão periódica da lista por especialistas, sistema de informações adequadas e processos de seleção e aquisição a preços acessíveis, mas com garantia da qualidade (SILVA, 2000).

Surgia, assim, a idéia do que seria conhecido mundialmente como "medicamento essencial", bem como a proposta de organizar, em uma relação (ou lista) quais seriam estes medicamentos essenciais. Esta idéia se consolidaria em 1977, com a publicação da primeira Lista Modelo de Medicamentos Essenciais pela OMS. O termo "Lista Modelo" deve-se ao entendimento da OMS de que não seria possível um conjunto de medicamentos essenciais aplicáveis, de modo geral, uniforme e mundialmente. Desse modo, cada país deveria adotar uma lista compatível com suas políticas no setor da saúde e de acordo com as necessidades da maioria de sua população.

Em setembro de 1978, devido à realização da Conferência Internacional Sobre Cuidados Primários em Saúde, na extinta URSS, foi publicada a "Declaração da Alma Ata", marco para políticas públicas de saúde, que incluía o fornecimento de medicamentos essenciais como um dos oito requisitos básicos aos cuidados primários a saúde (OPAS, 1978). 
Em 1990, foi publicada na $6^{\text {a }}$ lista de medicamentos essenciais, a definição, utilizada até hoje, de medicamentos essenciais como:

Aqueles que servem para atender as necessidades de assistência a saúde da maioria da população; portanto, estes produtos devem estar disponíveis em qualquer momento, nas quantidades adequadas e nas formas farmacêuticas que sejam requeridas.

A última publicação/atualização de modelo de lista de medicamentos da OMS é a 15 Edição, datada de março de 2007.

Atualmente, 156 dos 193 países membros da OMS possuem lista de medicamentos essenciais, dentre os quais, 127 tiveram atualizações nos dez últimos anos (OMS, 2008).

O Brasil é um dos países membros que possuem essa lista. Nesse sentido, é interessante verificar o pioneirismo brasileiro, uma vez que sua primeira relação de medicamentos essenciais foi publicada antes da recomendação da OMS em 1977. Considerando-se esta primeira lista, o país teve um total de oito listas entre 1964 (a primeira) até 2006 (última).

Em 1964, era denominada "Relação Básica e Prioritária de Produtos Biológicos e Matérias para Uso Farmacêutico Humano e Veterinário", a qual foi revisada em 1972, pela CEME. Em 1975, a nova revisão recebeu a denominação de RENAME, designação que perdura até hoje. Foram feitas ainda revisões em 1989, 1993, 2000 (quando foram introduzidas as diretrizes propostas pela OMS para elaboração de listas modelos, especialmente os critérios de eficácia e segurança), 2002 e a última, em 2006 (BRASIL, 2006).

Segundo CASTRO et al (2000), "uma lista oficial de medicamentos essenciais significa possibilitar a estruturação de toda a cadeia de medicamentos no país (...) deve ainda constituir-se no eixo condutor para as ações e promoção do uso racional de medicamentos, balizando a prescrição médica e a dispensação". 


\subsubsection{Definição de Uso Racional de Medicamentos}

Em novembro 1985, em função da Conferência de Especialistas em Uso Racional de Medicamentos da OMS, realizada em Nairobi, no Quênia, foi estabelecido uma definição o para o Uso Racional de Medicamentos (OMS, 1987). Esta definição perdura até hoje e é utilizada como guia para as discussões na área de URM. Nesta conferência foi definido que "o uso racional de medicamentos requer que o paciente receba a medicação apropriada para sua situação clínica, nas doses que satisfaçam as necessidades individuais, por um período adequado, e ao menor custo possível para ele e sua comunidade".

\subsubsection{Diretrizes para Políticas de Medicamentos}

Após ampla consulta internacional, a OMS publica em 1988 as "Diretrizes para o Desenvolvimento de Políticas Nacionais de Medicamentos". Este documento propõe apoio ao desenvolvimento, à aplicação e ao acompanhamento das políticas, com ênfase na necessidade de se passar da concepção para a aplicação e a avaliação da repercussão das políticas farmacêuticas nos países. Em 2001, foi publicada sua segunda edição (SOBRAVIME, 2001).

\subsubsection{Entidades Participantes na Discussão do URM}

As discussões ocorridas nos anos 70 propiciaram a este debate tomar corpo, no Brasil, entre os anos 80 e 90, quando diversos grupos de pessoas se reuniram em entidades (dentro e fora da academia) com a missão de discutir e tomar ações com relação ao uso racional de medicamentos. 
Esta discussão está na pauta de muitas entidades, associações, universidades, conselhos profissionais e de saúde, centros de farmacovigilância e de informações sobre o uso correto de medicamentos. Por isso, é impossível citar aqui absolutamente todos os grupos envolvidos, mas destacaremos alguns por sua frequência em materiais consultados e participação direta com o tema URM.

- No nível internacional, a Ação Internacional para Saúde - AIS (diversas entidades brasileiras participam desta rede). A AIS, fundada em 1981 na Genebra, Suíça, é uma rede de cooperação constituída por mais de 150 grupos de organizações e instituições de interesse público. Atualmente possui quatro escritórios de coordenação no plano mundial: HAl Europa, em Amsterdam, Holanda; a HAl-Ásia, em Colombo, Sri-Lanka; a HAl-Africa Nairobi, Kenya e a HAI America-Latina e Caribe, em Lima, Peru. Esta última criada em 1986. A preocupação com o uso racional de medicamentos é expressa na Missão da AIS: "A AIS é uma rede global independente que trabalha para aumentar 0 acesso aos medicamentos essenciais e melhorar seu uso racional". (AIS, 2008);

- A Sociedade Brasileira de Vigilância de Medicamentos SOBRAVIME, fundada em 1990. Já no seu primeiro Congresso, em 1991, discutia temas como a real necessidade dos medicamentos, a conscientização dos usuários e a regulamentação do mercado farmacêutico. Uma das ferramentas criadas pela SOBRAVIME para a conscientização sobre o assunto, foi o lançamento de um periódico - o "Boletim da SOBRAVIME" - que mais tarde seria reconhecido pela OMS (SOBRAVIME, 2001) como fonte pedagógica a respeito de produtos farmacêuticos e de seu uso apropriado. A 
SOBRAVIME publica, com freqüência, livros e estudos na área do uso correto de medicamentos;

- O Instituto Brasileiro de Defesa do Usuário de Medicamentos (IDUM) tem claramente o objetivo de "promover o uso racional de medicamentos", buscando coibir o abuso do poder econômico nas relações desse consumo;

- O Instituto Brasileiro de Defesa de do Consumidor - IDEC, uma associação de consumidores fundada em 1987, vem trabalhando especificamente, desde 1993, na área de medicamentos, fazendo pesquisas, participando na formação da RENAME, entrando com representações contra associações irracionais de medicamentos e conduzindo campanhas contra as propagandas farmacêuticas enganosas;

- O Grupo de Prevenção ao Uso Indevido de Medicamentos (GPUIM), um grupo de estudantes e professores de farmácia da Universidade Federal do Ceará (UFC) se organizou para trabalhar a promoção do uso racional de medicamentos. Este grupo se oficializou, em 1995, como núcleo de pesquisa e extensão do Departamento de Farmácia da UFC. A idéia inicial era de que um dos principais fatores para a utilização correta dos medicamentos seria o uso de informações confiáveis sobre os mesmos. Então sua estratégia foi buscar a democratização da informação farmacológica;

- Centros de Informações sobre Medicamentos:

- Centro Brasileiro de Informações sobre Medicamentos CEBRIM/DF - do Conselho Federal de Farmácia (CFF), iniciado em 1994; 
- Sistema Brasileiro de Informação sobre Medicamentos (SISMED), criado em 1996 e composto, hoje, por vinte e dois centros de informações distribuídos pelo Brasil;

- Programas de farmacovigilância. O Brasil é membro do Programa Internacional de Monitorização de Medicamentos da OMS. Em 2001, a Portaria 696/2001 instituiu o Centro Nacional de Monitorização de Medicamentos (CNMM), sediado na ANVISA, com o objetivo de coordenar as notificações sobre RAM's. Para fomentar as notificações, alguns programas foram desenvolvidos, como:

- Hospitais Sentinela - que estimula a notificação por hospitais públicos e privados;

- Farmácias Notificadoras - que estimula a notificação por farmácias e drogarias, públicas e privadas.

Lembramos também que, para discutir as questões relativas aos medicamentos, foi instalada, em dezembro de 1999 (encerrou-se em maio de 2000), uma Comissão Parlamentar de Inquérito (CPI) para tentar organizar esse complexo mercado, possibilitando maior acesso da população a medicamentos com menores preços e qualidade garantida (SILVA, 2000).

\subsubsection{As Câmaras Técnicas no Sistema Brasileiro de Vigilância} Sanitária

Ao longo de sua história, o sistema brasileiro de vigilância sanitária contou com diversas câmaras de consultores externos para subsidiar decisões na área de medicamentos. 
As câmaras técnicas, constituídas em diferentes períodos e contextos históricos, assumiram distintos papéis de acordo com as correlações de forças de seu momento histórico. Cabe ressaltar que, de uma forma ou de outra, a discussão sobre a questão do uso do medicamento há muito está presente institucionalmente no sistema brasileiro de vigilância sanitária.

Segue-se uma relação das câmaras existentes, a partir de 1976, quando da criação da Secretaria Nacional de Vigilância Sanitária (ANVISA, 2005):

- 1976: Câmara Técnica de Medicamentos;

- 1986: Comissão Nacional de Avaliação Técnica de Medicamentos (CONATEM);

- 1993: Comissão Técnica de Assessoramento em Assuntos de Medicamentos e Correlatos (CRAME);

- 1996: Comissão de Assessoramento para Assuntos de Medicamentos (CAAM);

- 1997: Comissão Nacional de Assessoramento TécnicoCientífico em Medicamentos (CONATEM);

- 2001: Câmara Técnica de Medicamentos (CATEME).

1.3.6 Fatos Recentes no Debate Sobre o Uso Racional de Medicamentos

Em 2005, foi realizado o I Congresso sobre o Uso Racional de Medicamento em Porto Alegre, Rio Grande do Sul, evento reeditado em outubro de 2007, em Florianópolis, Santa Catarina.

O II Congresso sobre o Uso Racional de Medicamento, em Florianópolis, foi uma promoção conjunta do MS, ANVISA, OPAS/OMS e UFSC (Universidade Federal de Santa Catarina). O evento buscou cobrir todos os fatores relacionados ao uso correto dos medicamentos: a 
assistência farmacêutica, a propaganda de medicamentos, a farmacovigilância, os centros de informação de medicamentos, a articulação de ensino e pesquisa no URM e as políticas de saúde e de medicamentos. $O$ Congresso contou ainda com 431 trabalhos científicos abordando os diversos aspectos sobre o URM ${ }^{13}$.

A questão do URM tornou-se tão significativa que foi incluída na agenda política do Ministério da Saúde que instituiu, através da Portaria no 1.555, de 27 de junho de 2007, o "Comitê Nacional para a Promoção do Uso Racional de Medicamentos" (BRASIL, 2007). Este comitê é composto por dezenove órgãos/instituições, entre outros ministérios, OPAS e conselhos profissionais. Um dos objetivos do comitê é a proposição de estratégias para o URM em nível nacional.

Um outro fato que demonstra que o tema encontra-se na pauta de discussões é o espaço que o Ministério da Saúde tem reservado ao assunto. O portal do Ministério da Saúde, no dia 09 de outubro de $2007^{14}$, estampava em sua página principal o símbolo de Hórus ${ }^{15}$, fundindo o "R" de "Recipe" com o "R" de "Racional", imagem que destacava um informe sobre "O Uso Racional de Medicamentos", direcionado aos profissionais da saúde e a população.

\footnotetext{
${ }^{13}$ Os 431 trabalhos estão relacionados no Caderno de Programa do II Congresso Brasileiro sobre o Uso Racional de Medicamentos - 15 a 18 de outubro de 2007. Florianópolis - Santa Catarina. Disponível em: http://www.urm.ufsc.br. Acesso em 09/10/07.

${ }^{14}$ Disponível em http://portal.saude.gov.br/portal/saude/area.cfm?id area=1141. Acessado em 09/10/07.

${ }^{15} \mathrm{O}$ símbolo de Hórus, deus egípcio, surgiu há cinco mil anos. Hórus, filho de Ísis, perdeu a visão após um ataque malicioso do demônio Seti, mas a recuperou quando sua mãe invocou a ajuda de Tot. Daí em diante, médicos egípcios recorreram ao deus Hórus e usavam como símbolo o olho, que foi estilizado na figura inicial. O símbolo significa saúde e felicidade. A igreja, em seu turno, esforçou-se para cristianizar o símbolo, escrevendo-o com duplo $R$ e propalou-se ser uma invocação ao anjo Rafael e sua réplica Responsum Raphaelis [a]. Mas os alquimistas, mais tarde, retornaram ao símbolo egípcio original, perdurando até os dias atuais. Na Era da Razão, o símbolo foi racionalizado e diz-se que é a inicial $\mathrm{R}$ do latim "recipe", receba esta prescrição, ou tome estes princípios ativos. (In SOBRAVIME 2001).
} 


\subsection{O URM E A MERCANTILIZAÇÃO DA DOENÇA}

Este capítulo teve o intuito de mostrar que a utilização do medicamento não é algo trivial; muito ao contrário, requer a utilização de rigorosos e complexos critérios técnicos e científicos. Seu uso indiscriminado traz sérios problemas ao indivíduo e à saúde pública e por isso este uso vem sendo discutido há algumas décadas e cada vez mais tem ocupado um espaço de destaque na agenda das políticas públicas. O capítulo também teve o propósito de expor que este debate não está alheio às questões que mais influenciam o uso irracional do medicamento: as pressões econômicas que o medicamento recebe ao ser colocado como um produto no mercado. A idéia, então, foi deixar evidente a importância de se dar um tratamento específico a este "produto" sob uma lógica sanitária e não deixá-lo a mercê de outras lógicas. No próximo capítulo, exploraremos o debate que aponta justamente este descaminho. 


\section{O DEBATE SOBRE A MERCANTILIZAÇÃO DA DOENÇA}

Neste capítulo será apresentado o debate sobre a mercantilização da doença. Em primeiro lugar será feita a conceituação do termo "mercantilização da doença". Em seguida, serão apresentados seus antecedentes históricos, o contexto atual que propiciou a intensificação deste fenômeno e, por fim, serão expostos alguns casos discutidos nesse debate sobre a mercantilização da doença.

O debate sobre a mercantilização da doença surge nos países de língua inglesa, sobretudo nos Estados Unidos, utilizando freqüentemente o termo Disease Mongering. Por isto, a primeira seção definirá e conceituará este termo.

A segunda seção será dedicada a entender os antecedentes históricos desse fenômeno. Ela resgatará a história dos primeiros produtos terapêuticos preparados em escala, sua proteção patentárea e a forma peculiar de promovê-los. Esse panorama histórico fornece uma compreensão de quão fértil é o campo que propiciará o fenômeno da mercantilização da doença.

A terceira seção terá um olhar para o novo fenômeno que se estabelece. A competição deste mercado privilegiado pela proteção patentárea conduzirá a intensificação da mercantilização através da colonização econômica em outras áreas da atividade humana, como os espaços acadêmicos, a área da medicina, as atividades de pesquisa pública e outras áreas exploradas nesta e em outras subseções.

A quarta (e última) seção apresentará alguns casos discutidos no debate sobre a mercantilização da doença, no intuito de ilustrar como estão se realizando, na prática, estas colonizações em conseqüência da intensificação deste fenômeno. Estes casos foram reconstruídos de artigos publicados por autores independentes que participam ativamente deste debate. 


\subsection{CONCEITUANDO DISEASE MONGERING}

A mercantilização da doença é uma tradução (ou adaptação) que este trabalho adotará do termo desenvolvido nos Estados Unidos disease mongering.

Segundo ARONSON (2007) "o termo disease monger parece ter sido introduzido pela jornalista estadunidense Lynn Payer em 1992 e popularizado, entre outros, pelo jornalista australiano Ray Moynihan, embora um termo relacionado 'nostrum monger'é utilizado desde o século XVIII".

$\mathrm{Na}$ literatura brasileira foram encontradas algumas referências traduzindo o termo disease mongering como "promoção da doença" (SILVA, 2005 e 2006) e outras, preferindo a tradução "mercantilização da doença" (ARAUJO, 2004 e BRASIL, 2004).

Em Portugal, normalmente é utilizado o termo "promoção da doença" (SOUSA, 2007 e MELO, 2007). Na defesa desta tradução, MELO (2007) argumenta que "o termo inglês monger (pessoa que faz propaganda, que promove algo pouco credível ou indesejável) faz referência ao caráter comercial implícito na expressão disease mongering, pelo que podemos traduzi-lo como a Promoção da Doença".

Para definir qual terminologia adotar, foram pesquisados os significados das palavras "promoção" e "mercantilizar"16.

A palavra promoção possui dois sentidos: o sentido de elevação e, na perspectiva comercial (o que nos interessa), o "conjunto de atividades que visam a fortalecer a imagem de uma marca, instituição, indivíduo, etc. ou a influenciar pessoas na escolha de determinado produto ou serviço".

Mercantilizar significa "dar espírito ou pendor mercantil a; tornar objeto de comércio".

A palavra promoção parte, então, da idéia de algo previamente concebido para o comércio, de "espírito comercial". Este entendimento leva

\footnotetext{
${ }^{16}$ Os significados de "promoção" e "mercantilizar" foram retirados do Novo Dicionário Aurélio de Língua Portuguesa. Curitiba: Positivo, 2004.
} 
a crer que a sua adoção não parece ser adequada quando nos referimos à doença na medida em que ela não é, em primeira instância, objeto concebido para o comércio.

O significado da palavra mercantilizar ("tornar objeto mercantil") parece estar consoante com o principal fenômeno debatido: a transformação da doença em objeto de comércio. Isso se verifica ao estudar o contexto no qual foi concebido o termo disease monger.

Dessa forma, a opção pelo uso da palavra mercantilização torna-se a mais adequada, uma vez que a mesma carrega consigo a idéia de "tornar objeto de comércio". Assim, finalmente, optou-se para este trabalho, adotar o termo "mercantilização da doença".

\subsection{ANTECEDENTES HISTÓRICOS - OS NOSTRUM MONGERS}

Como citado anteriormente, existe um termo relacionado a este debate, nostrum monger, utilizado desde o século XVIII (ARONSON, 2007).

APPLBAUM (2006), antropólogo médico, em um artigo sobre a mercantilização da doença, faz referência sobre os nostrum mongers, relacionando-os historicamente com este tema.

Embora se acredite que semelhantes práticas da mercadização ${ }^{17}$ farmacêutica contemporânea sejam um fenômeno moderno, elas, na verdade, são uma continuação direta da publicidade de medicamentos patenteados do século XIX. "Nostrum-mongers", como o escritor Henry James os denominou, são famosos na história da publicidade como tendo sido os criadores e os principais utilizadores das técnicas publicitárias. Os vendedores do nostrum foram os pioneiros com a publicidade impressa, uso de marcas registradas, embalagens distintas, estratégias de estímulo a demanda e até 0 desenho e a criação de almanaques médicos que funcionavam como veículos de promoção para o divulgação de doenças. $O$ irmão e psicólogo de Henry James, William James, estava tão amargurado com a sua "abominação a este tipo de publicidade médica" que em 1894 ele

\footnotetext{
${ }^{17}$ Utilizaremos, na medida do possível, a palavra mercadização como tradução da palavra marketing. Esta tradução é utilizada por diversos sanitaristas e pela SOBRAVIME desde 1994, julgando a "necessidade de substituir o emprego lingüístico abusivo e subserviente de marketing" (SOBRAVIME, 2001).
} 
declarou que "os autores destas propagandas deveriam ser tratados como inimigos públicos e não deveriam receber nenhuma misericórdia”.

A questão da marca registrada (ou patente) é um dos eixos centrais para a discussão da mercantilização da doença, como veremos adiante. Os nostrum mongers são os pioneiros de seu uso. Vejamos, então, parte de sua história.

James Harvey Young (1915-2006), professor de história social e membro da FDA, dedicou-se a pesquisar a história estadunidense da regulação de alimentos e medicamentos. Dentre suas publicações, o livro The Toadstool Millionaires (1961) abrange o período da nascente das patentes dos Estados Unidos colonial até o ano de 1906. Neste livro, Young retorna à Inglaterra do século XVIII para entender como os primeiros "medicamentos" patenteados surgiram nos Estados Unidos.

YOUNG (1961) descreve o século XVIII como um período de iluminação, mas que herdara, todas as superstições dos séculos passados. Um espírito científico iluminava diversas áreas do conhecimento e "havia homens ansiosos em transferir para os campos da biologia e da medicina a revolução científica que refizera a física e a astronomia”. O problema é que, em razão do campo da doença e saúde ser tão vasto e complexo, a velocidade do avanço desta área do conhecimento não conseguia acompanhar as demais, sendo a soma total do novo conhecimento médico do período ainda muito pequeno, permitindo que o peso das tradições pressionasse o campo de conhecimento tanto que "deixava perplexos até os melhores cientistas da época".

Este período foi também uma época de construção de sistemas (system-making). Entretanto, a pesquisa biológica parecia não encontrar leis universais em sua área - como, por exemplo, a gravitação - mas apenas mais complicações e confusões. Por isso, na ansiedade de conseguir explicações simples para as doenças, alguns pesquisadores muitas vezes negligenciavam o método científico ou o seguiam até certo ponto. Segundo 
YOUNG (1961), "eles construíram vastos esquemas teóricos médicos pela simples lógica especulativa".

Este campo de conhecimento estava inserido, então, num contexto bastante nebuloso e confuso. YOUNG (1961) descreve algumas características, como o fato de ainda se seguirem antigas tradições médicas em contraponto a correntes de pensamento claramente opositoras a elas e que as rebatiam. Por exemplo, naquele momento eram correntes as idéias de Galeno e sua teoria dos humores, cujo adoecimento devia-se a um desequilíbrio entre os quatro humores do corpo: sangue, muco, cólera (bile amarela) e melancolia (bile negra). Muitos medicamentos ainda eram pensados em termos de restabelecer a harmonia entre estes humores. Por outro lado, ainda no século XVI, Paracelso - que tinha formação em química - desprezava tanto esta tradição que chegou a queimar as obras de Galeno. Paracelso entendia que a química deveria abandonar o seu esforço em fazer ouro a partir de outros metais e devotar-se a encontrar medicamentos para curar doenças. Assim, ele e seus discípulos introduziram os minerais na preparação de medicamentos.

Simultaneamente, o conhecimento médico ainda obedecia a velhos costumes e mitos. Um dito (dictum) alimentava a idéia de que "quanto pior um medicamento utilizado, maior seu poder curativo" e induzia o uso de substâncias repulsivas como medicamentos. Nessa concepção, a doença era vista como um invasor que deveria ser combatido por uma substância tão repugnante quanto ela mesma. Substâncias como cascos de cavalos e bichos-de-conta (tatuzinhos) secos podem ser encontrados em formulários terapêuticos publicados por três hospitais de Londres no século XVIII.

Com a expansão ultra-marina, os séculos XVII e XVIII tinham inundado a Europa com novos produtos do mundo todo. Plantas exóticas foram colocadas rapidamente em uso terapêutico. Em meados de 1650 o jardim medicinal da Universidade de Oxford, iniciado em 1623, tinha cerca de 600 espécies nativas e mil plantas trazidas do além mar.

Esse contexto de diferentes crenças, idéias científicas (e todas suas dificuldades) e aumento acelerado de informações, fez com que a 
medicação dos séculos XVII e XVIII fosse "seguramente uma feira de leigos (laissez- faire)". Uma enorme quantidade de remédios era justificada em termos de teoria especulativa ou de presumida experiência empírica. Nenhum leigo com desejo de sugerir um novo medicamento sentia alguma restrição legal ou moral para fazê-lo. O fato de práticos ingleses, que possuíam algum prestígio e status, se associarem ao Colégio Médico de Londres (um grupo fundado durante o acelerado interesse científico da Renascença) favorecia o crescimento dessa tolerância.

Associado a isso, uma antiqüíssima concepção de que membros de uma determinada profissão não poderiam humilhar-se trabalhando com as próprias mãos fizera com que a cirurgia e a experimentação em laboratório fossem malvistos. Os proponentes de sistemas teóricos conflituosos demoravam-se em seus debates e os médicos, preocupados com questões de promoção e primazia, recusavam-se a expandir seus atendimentos.

As multidões tinham que procurar alternativas para se tratarem. Elas acharam isto nas mãos de cirurgiões e práticos de farmácia, ainda com pouca reputação, mas aumentando sua aprovação devido a esta grande demanda popular. A questão é que haviam mãos de bem intencionados empíricos, mas também de charlatões inescrupulosos.

Todo este contexto foi favorável, segundo YOUNG (1961), para que Ingleses engenhosos combinassem as questões médicas com o entusiasmo promocional da época.

Lembremo-nos que, segundo BERMUDEZ (1995), até meados do século XIX, a produção de medicamentos era essencialmente artesanal, em pequenos estabelecimentos, a partir de drogas de origem botânica, as quais eram preparadas por farmacêuticos e médicos. Apenas no início do séc. XX é que se iniciaria a pesquisa e a produção de medicamentos. A síntese química e a fermentação começariam a partir dos anos 30 e o surgimento da indústria farmacêutica global só veio a ocorrer entre as décadas de 40 e 50 .

Então, aqueles engenhosos ingleses a que se refere YOUNG (1961), à parte da produção artesanal de medicamentos da época, começaram a produzir, em escala, produtos que eram preparados, rotulados e embalados 
para serem vendidos diretamente à população. Os nostruns, como foram batizados, podem ser considerados os antecessores do medicamento industrializado moderno.

Esses ingleses, alegando a autoria desses nostruns, decidiram patenteá-los em pleno século XVIII para evitar que concorrentes os copiassem e os comercializassem.

Os significados da palavra nostrum, encontrados no The Century Dictionary $^{18}$, são os seguintes: "do latim 'nosso'; admite-se que o nome se refira ao hábito de charlatões (quacks) e outros anunciantes de reivindicar virtudes especiais para seus produtos 'de nossa própria fabricação (feitura)'; ou um medicamento que possui os seus ingredientes e o método de combinação entre eles, mantido em segredo com o propósito de restringir os lucros da venda para o inventor ou o proprietário, especialmente o medicamento charlatanesco (quack medicine)". No dicionário The American Heritage $^{19}$, é encontrado ainda: "a forma favorita para a solução de algum problema; nosso (próprio; our own), de nós (isto é, inventado e feito pelo vendedor)".

Ou seja, os nostruns, além de significar que "eram produzidos por nós mesmos", desde a acepção de sua palavra, já suportava a idéia de que era a "melhor forma de resolver o problema".

Um dos primeiros produtos descritos, na história, com estas características foram as Pílulas de Anderson (Anderson's Pills), datadas de 1630. Era um preparado a partir de uma fórmula supostamente aprendida em Veneza por um escocês que dizia ser médico do Rei Charles I. Em 1712, o Elixir de Richard Stoughton foi o segundo composto medicinal a receber uma patente inglesa. Em 1726, uma patente também foi concedida para o produto Dr. Bateman's Pectoral Drops. Curiosamente o detentor da patente não era um médico chamado Bateman e sim um homem de negócios,

\footnotetext{
${ }^{18}$ The Century Dictionary - An encyclopedic lexicon of the English language, New York: The Century Co., 1914.

${ }^{19}$ The American Heritage Dictionary of the English language, New York: American Heritage Publishing Co. Inc., 1969.
} 
chamado Benjamin Okell, que se aliou a um grupo de empreendedores da área promocional, a um depósito e a uma gráfica em Bow Churchyard. Duas décadas mais tarde, Michael e Thomas Bretton patentearam "um óleo extraído de uma rocha dura para a cura de reumatismo, escorbuto e outros casos". No ano posterior, um boticário erudito, Jonh Hooper, recebeu a patente para o fabrico das "Pílulas Femininas" que carregavam seu nome.

Quase que simultaneamente a idéia de preparar, embalar e patentear os nostruns, surgira a idéia de promovê-los: provavelmente a primeira referência impressa nos Estados Unidos de um nostrum inglês (embora ainda não patenteado) é datada de 04 de outubro de 1708. O Boston NewsLetter publicava que estava a venda na loja Nicholas Boone o "Elixir Salutis de Daffy, muito bom, ao preço de quatro shillings e seis pences a meia garrafa".

Segundo PARTRIDGE (1937), no livro "O detector de charlatanismo" do irlandês Jonh Corry, publicado na Inglaterra em 1802, há uma passagem muito interessante sobre o charlatão, curandeiro ou ainda mascate (este último, o autor designava como "itinerante empírico", pois, no século XVI, a palavra "empírico" designava um doutor ou cirurgião não treinado, o que logo veio a significar curandeiro ou charlatão). A passagem do livro de CORRY (1802, apud PARTRIDGE, 1937), diz:

O mascate, vestido de verde e dourado, com sua cabeça sagaz adornada com uma peruca e com suas mãos beneficentes cheias de grandes pílulas e garrafas, elevou-se ao palco, enquanto o jovial Andrew, que tinha reunido pessoas pelo som de sua trombeta, aproximou-se e saltou para próximo de seu mestre, com o qual ele entrou em um diálogo cheio de humor e mímicas para deleite do populacho aos arredores. Quando as graças e as proezas do Sr Merryman tinham comovido os espectadores em um bom humor universal, o Doutor se aproveitou da sua hilaridade e dispensou seus nostrums para os crédulos, os quais, mitigados, davam seu dinheiro pelas inestimáveis caixas de pílulas, pomadas cicatrizantes ou garrafas de licores estimulantes (Cordial) as quais estavam investidas não só pelo poder de cura de doenças existentes como também para operar um tipo de mágica preventiva para toda doença ou indisposição.

O próprio PATRIDGE (1937) complementa que "isto lembra que nostrum vem do latim noster, ou nosso, ou seja, a idéia de que o 'nosso 
remédio' é sempre o melhor é a origem do uso desta palavra e a razão pela qual, desde sua incorporação ao idioma inglês, remete a uma medicina ou remédio charlatanesco".

A preocupação com a questão dos vendedores do nostrum (os nostrum mongers) acompanha a história da medicina. Em um artigo assinado pelo professor Barker, datado de 1908, ele defende a importância da inclusão de laboratórios médicos (como os de fisiologia, anatomia, etc.) como ferramenta de aprendizado no ensino médico - entendendo que, desta forma, o estudante visualiza, na prática, entre outras coisas, a ação das drogas. BARKER (1908) também enfatiza que:

O estudante então treinado (nesses laboratórios - grifo nosso) estará com menor probabilidade de cair nas garras dos fabricantes de medicamentos patenteados e dos nostrum monger, do que o médico que obteve todo seu conhecimento a respeito da ação das drogas apenas em livros, conferências ou de circulares de fabricantes

Nas próximas seções se verificará que a história da constituição dos nostrum mongers e suas ações de fabricar, embalar, patentear e divulgar os nostrums (ou "medicamentos"), aproveitando-se de um contexto confuso sobre a conceituação da relação saúde-doença e, simultaneamente, interferindo nessa conceituação, de certa forma é o gérmen do fenômeno que tomará contornos próprios e se intensificará dando origem ao debate contemporâneo sobre a mercantilização da doença.

\subsection{A INTENSIFICAÇÃO DO FENÔMENO "MERCANTILIZAÇÃO DA DOENÇA" E O SURGIMENTO DO DEBATE}

Como visto na seção anterior, a mercantilização da doença não constitui em si um processo social absolutamente novo. Ela assume distintas configurações ao longo de seu desenvolvimento histórico. Como visto, desde o século XVI, na figura dos nostrum mongers que traziam pílulas investidas 
com um "tipo de mágica preventiva para toda doença ou indisposição", já é possível estabelecer o nascimento do movimento que caminhará em direção a este fenômeno.

Contudo, é importante destacar a nova conformação e a intensificação desse processo a partir dos anos 90 motivando um crescente número de publicações, relativas ao tema, nesse período e nos anos $2000^{20}$.

A nova configuração estabelecida com o avanço da lógica do pensamento econômico sobre outras lógicas ocorre, em grande parte, devido o acelerado avanço da tecnologia, tanto no sentido de tecnologia como aplicação do conhecimento científico acerca do produto (no caso, o medicamento) como acerca das formas de como o capital irá abarcar outras formas do pensamento humano. O contexto histórico deste período, como será discutido, será propício para a marcha acelerada deste fenômeno.

Um marco fundamental foi o lançamento do livro "Disease mongers: how doctors, drugs companies, and insurers are making you feel sick" da jornalista estadunidense Lynn Payer, em 1992, o qual descreve a "mercantilização da doença" como a ampliação dos limites da doença. PAYER (1992) sistematizou dez táticas utilizadas para se conseguir isto:

- Tomar uma função normal e inferir que há algo errado com ela e que deve ser tratada;

- Alimentar um sofrimento que necessariamente não exista;

\footnotetext{
${ }^{20}$ A começar pelo ano de 1992, data do lançamento do livro da jornalista Lynn Payer, é notável o crescente número publicações sobre o tema. Marcelo Leite, jornalista e colunista da Folha de São Paulo em artigo intitulado "Pílulas amargas" no Caderno Folha llustrada de 19/03/2005, pág. E5, comenta sobre as publicações das editoras de língua inglesa. Diz ele "Eis uma lista apenas dos livros lançados no ano passado sobre o assunto: "The Truth About the Drug Companies", de Marcia Angell (Ramdon House); "On the Take: How Medicine's Complicity with Big Business Can Endanger Your Health", de Jerome Kassirer (Oxford University Press); "The \$800 Million Pill: The Truth Behind the Cost of New Drugs", de Merrill Goozner (University of California Press); e "Powerful Medicines: The Benefits, Risks, and Costs of Prescription Drugs", de Jerry Avorn (Knopf)".
} 
- Definir uma larga proporção da população como possível sofredora de uma "doença";

- Definir uma "condição" como deficiência ou desequilíbrio hormonal;

- Conseguir os assessores de mídia certos;

- Modelar as questões de uma maneira muito particular;

- Usar estatísticas de forma seletiva para exagerar os benefícios do tratamento;

- Usar o ponto final errado ${ }^{21}$;

- Promover o uso da tecnologia como algo que está livre de riscos;

- Tomar um sintoma comum que poderia significar algo trivial e fazêlo soar como se fosse sinal de uma doença grave.

MOYNIHAN (2006) entende que o eixo central desse debate é a transformação de pessoas saudáveis em doentes para facilitar a venda de tratamentos. Para lograr este objetivo, trabalha-se, basicamente, na alteração das definições de saúde e doença ${ }^{22}$ em um dos seguintes sentidos:

21 Using the wrong end point é a frase, no original. Payer quer dizer que muitas vezes a finalidade de uma determinada ação é "falseada"; a autora exemplifica a idéia com a mamografia - diz ela que as campanhas para mamografia se gabam pelo seu sucesso mais por causa do número de mulheres que aderem ao exame do que, necessariamente, se este aumento de uso da tecnologia de fato reduziu o risco de morrer por câncer de mama.

22 Embora seja uma questão de extrema pertinência, não adentraremos na enorme discussão das definições de "saudável" ou "saúde" e "doente" ou "doença". Entendemos que estas definições variam em termos históricos e se abrem em maior ou menor medida a determinações extra-sanitárias e em diferentes contextos sociais, mas não se trata, exatamente, do objeto desta dissertação. O que nos importa é, entretanto, verificar que o 
- Pelo estreitamento da definição de saudável, de modo que aspectos ordinários da vida possam ser rotulados como patológicos ou

- Pela expansão da definição de doença, fazendo com que problemas moderados ou fatores de risco sejam moldados como doenças.

Segundo o autor, isto ocorre por uma profunda campanha de "conhecimento às doenças" que está mais preocupada em vender do que educar. Toda a doença que for alvo de tratamento por uma medicação passa a ser amplamente divulgada para que os profissionais-chaves e o público em geral passem a conhecê-la. Esta campanha ocorre por alianças informais entre corporações farmacêuticas, empresas de relações públicas, grupos médicos e de pacientes que influenciam a opinião pública e aqueles que definem as políticas de saúde e de medicamentos.

Esta campanha tem diferentes estratégias. Aspectos ordinários da vida sendo medicalizados (como a menopausa); problemas moderados retratados como doenças graves (como a síndrome do cólon irritável); manipulação dos fatores de risco que passam a serem forjados como doenças (como a alta taxa de colesterol no sangue e a baixa densidade óssea), entre outros.

Condições pouco conhecidas pela população e ainda pouco reconhecidas pela comunidade científica são popularizadas, como a síndrome das pernas inquietas e a disfunção sexual feminina. Em ambos os casos, a estratégia é inflar as estimativas de prevalência. No caso da disfunção sexual feminina há um empreendimento de esforços para convencer que $43 \%$ das mulheres têm essa condição. Embora esta

debate em questão aponta claramente para um deslocamento destas definições no sentido descrito por Moynihan, possibilitando a inclusão de um número cada vez maior de pessoas no território daquilo que podemos chamar de "doença" e que devem ser tratadas; e necessariamente tratadas com medicamentos, como veremos. 
disfunção e sua estimativa são muito contestadas e discutidas, ela é amplamente divulgada como um dado certo.

KANE RACED (2006), da Universidade de New South Wales (Austrália), acredita que a mercantilização da doença combina dois aspectos chamados de "pesadelos da vida contemporânea":

- A "comodificação" (ou a "mercadorização") que é a conversão das relações sociais em coisas e

- A "patologização", especificamente a excessiva patologização na rotina diária de nossas vidas.

A autora entende que, a partir de uma concepção construída historicamente para classificar a vida em termos de "função" e "disfunção", criou-se uma imposição de um padrão universal de comportamento e de experiências humanas. Esta imposição introjeta uma idéia de que condições materiais e sociais, que afetam nossas vidas, possam ser resolvidas por uma pílula. Ela chama, então, essas pílulas de "drogas para o estilo de vida" ("lifestyles drugs").

RACED (2006) conclui que reduzir a imposição de normas (como saúde e doença) que possibilitem ter a vida regida por uma coisa (objeto ou produto) representa uma enorme oportunidade de negócios. Forjar esta função às drogas, implicaria em políticas de segurança e valor que estejam menos condicionadas a determinações científicas e autoridades profissionais e mais às avaliações éticas e de entendimento das questões ético-filosóficas sobre o pensamento. Uma das questões cruciais emergentes desta proposição é como, nestas condições, ser possível desenvolver uma verdadeira cultura de "consumidores" informados, não-enganados e éticos.

A emergente preocupação com 0 assunto desembocou, mais recentemente, na realização I Congresso Mundial Sobre a Mercantilização das Doenças, em abril de 2006, na Austrália. 
Os principais temas abordados neste Congresso foram a criação das doenças, vendas de sexo e estilos de vida, questões com a saúde mental, o papel da mídia, mulheres e crianças como alvos e estudos de casos. Os estudos de caso foram transformados em artigos e publicados no site Plos Medicine ${ }^{23}$.

A seção 2.5 apresentará, resumidamente, alguns casos deste debate, descritos em artigos e publicações. Antes, porém, será apresentado, na próxima seção, o contexto histórico contemporâneo que propiciou a intensificação deste fenômeno e o conseqüente surgimento deste debate.

\subsection{O CONTEXTO HISTÓRICO CONTEMPORÂNEO DA INDÚSTRIA}

\section{FARMACÊUTICA}

Para entendermos os fatores que propiciaram a intensificação da mercantilização da doença a partir dos anos 90, é necessário verificarmos 0 contexto histórico que estavam inseridos os atores deste fenômeno neste período.

ANGELL (2004), explica que, a partir dos anos 2000, uma série de medicamentos, campeões de vendas em seus mercados, teriam suas patentes se expirando no intervalo de apenas alguns anos, entre uns e outros $^{24}$.

O epicentro de todos os fenômenos que se seguiriam ocorreu nos Estados Unidos. O país, com menos de cinco por cento da população mundial, corresponde a $50 \%$ do mercado global em medicamentos sob prescrição médica (MOYNIHAN, 2005) e possui nove entre as vinte maiores

${ }^{23}$ Disponíveis em http://medicine.plosjournals.org/ Volume 3, № 4, e 132, 140, 146, 170, $178,185,182,189,191,198$ e 213.

24 A autora afirma que é estimado um volume de venda de US\$ 35 bilhões por ano dos medicamentos mais vendidos os quais as patentes expirariam a partir de 2000. Só para citar dois exemplos de campeões de vendas, em 2001 expiraram as patentes do Prozac, do Eli Lilly, e do Prisolex, da Astra Zeneca (este último atingiu a marca de US\$ 6 bilhões/ano em seu apogeu). 
indústrias farmacêuticas do mundo (THE CENTER OF PUBLIC INTEGRITY, 2005).

Provavelmente prevendo este "desastre" em seus lucros, no início dos anos 80 e começo dos anos 90, inicia-se uma série eventos no sentido de minimizar ou evitar os prejuízos que viriam a ocorrer futuramente. "Embora os lucros desta indústria ainda ultrapassassem qualquer patamar que outros setores, algo deveria ser feito, pois, para Wall Street, o que importa não são os lucros do presente e sim, os do futuro (ANGELL, 2004)".

Dessa forma, uma série de manobras, no âmbito legislativo estadunidense, entre os anos 80 e 90, envolveram dois aspectos fundamentais na questão das patentes de medicamentos e foram caracterizadas por Angell. Essas manobras ao mesmo tempo contribuíram e fazem parte da transformação do papel que essa indústria passará a assumir cada vez mais e que propiciará o fenômeno da mercantilização da doença. Os dois aspectos, objetos dessas manobras são:

- A pesquisa e o desenvolvimento, única forma de trazer novos produtos patenteados e garantir os níveis de lucratividade e

- A extensão da vigência das patentes existentes.

As duas próximas seções abordarão cada um deles isoladamente, embora os mesmos sejam complementares e estejam obedecendo a um mesmo movimento.

\subsubsection{Pesquisa e Desenvolvimento}

ANGELL (2004) entende que, no governo Reagan nos anos 80, houve a transformação da idéia de que ser rico não é apenas honroso, mas também uma virtude, consolidando cada vez mais a concepção de um 
mundo divido entre vencedores (winners) e perdedores (losers), e os vencedores são ricos porque merecem sê-los. Esta concepção fez com que várias instituições logo buscassem a se juntar às fileiras dos vencedores.

A indústria é uma delas. Sabendo da necessidade de substituir seus medicamentos que teriam suas patentes expiradas por outros com novas patentes, e preocupada com a pesquisa básica que é extremamente custosa, a indústria encontrou, naquele cenário dos anos 80 , o ambiente propício para a promulgação de uma série de leis "projetadas para acelerar a tradução de pesquisa básica financiada por impostos em produtos novos e úteis - um processo às vezes designado pela expressão 'transferência de tecnologia"”.

Nesse sentido, provavelmente a lei mais importante promulgada, foi a lei Bayh-Dole, nos anos 80. Ela permitiu que universidades e pequenas empresas patenteassem descobertas decorrentes de pesquisas patrocinadas pelos National Institutes of Health $(\mathrm{NIH})$, o principal distribuidor de recursos provenientes de impostos para a pesquisa médica, e depois concedessem licenças exclusivas a laboratórios farmacêuticos.

Até então, as pesquisas financiadas pelos contribuintes pertenciam ao domínio público, ficando disponíveis para qualquer empresa. Mas agora as universidades podiam patentear e licenciar suas descobertas, além de cobrar royalties. Outras legislações que vieram neste esteio permitiram que os $\mathrm{NIH}$ fizessem acordos de transferência direta das descobertas para a indústria.

Nas palavras de ANGELL (2004):

Essas leis significam que os laboratórios farmacêuticos já não precisam depender de sua própria pesquisa para novos medicamentos, e pouco dos maiores ainda o fazem. Para isso, cada vez mais eles contam com o setor acadêmico, pequenas empresas principiantes na área de biotecnologia e com os NIH. Atualmente, pelo menos um terço dos medicamentos comercializados pelos principais laboratórios é licenciado por universidades ou pequenas empresas de biotecnologia e esses costumam ser os mais inovadores. Embora a lei Bayh-Dole tenha sido nitidamente uma mão na roda para os gigantes da indústria farmacêutica (...) é questionável se ela resultou num benefício líquido e certo para o público. 
Por outro lado, entre as outras instituições que se juntaram à fileira dos vencedores, encontramos as universidades e os hospitais escolas, que tiveram seus etos transformados por esta concepção. Essas instituições, antes sem fins lucrativos, passaram a se ver como "parceiras" da indústria, ficando tão entusiasmadas quanto qualquer empresário em transformar suas pesquisas em ganhos financeiros. Professores de faculdades de medicina fizeram acordos lucrativos com as empresas farmacêuticas: um dos resultados foi a crescente tendência favorável à indústria na pesquisa médica - exatamente onde não cabia uma tendência desta natureza. Membros do corpo docente começam a questionar seu estilo de vida "frugal, porém elegante" pela concepção da riqueza. Em outras palavras, é como se perguntassem "de que adianta ser inteligente se não se está rico?". Um exemplo do conflito de interesses que ANGELL (2004) suscita é o fato de que estas Universidades passam a ganhar royaties e "por ser do seu próprio interesse, as universidades raramente criticam os preços exorbitantes dos medicamentos derivados de sua própria pesquisa".

Para entender como funciona este novo mecanismo de financiamento da pesquisa básica, a próxima subseção se dedicará a explicá-lo mais detalhadamente.

\subsubsection{Etapas da Pesquisa e Desenvolvimento}

A primeira etapa de uma pesquisa é chamada pesquisa básica, na qual se busca entender a natureza da doença, ou o que está ocorrendo de "errado" no corpo, e o mecanismo desta doença. Esta etapa é praticamente toda realizada e financiada pelos $\mathrm{NIH}$. A indústria começa a se envolver, um pouco mais, na etapa da pesquisa aplicada, mas, principalmente, na etapa de desenvolvimento de produto (PUBLIC CITIZEN, 2001). Os levantamentos expostos logo adiante deixam claro que a indústria entra na pesquisa e 
desenvolvimento apenas quando há fortes indícios de que a droga pesquisada poderá ser um produto comercializável; estes dados confirmam o pouco envolvimento da indústria farmacêutica na etapa da pesquisa básica, embora ela seja a entidade que mais se beneficie da política patentárea:

- Um estudo do Instituto Tecnológico de Massachussets (MIT) demonstrou que, das 21 drogas mais importantes, introduzidas entre 1956 e 1992, 14 delas (67\%) tiveram participação de fundos de pesquisas públicas para sua descoberta e desenvolvimento (PUBLIC CITIZEN, 2001);

- Um relatório de 1997 do Bureau Nacional de pesquisa econômica (National Boreau of Economic Research) concluiu que, dos 21 medicamentos mais eficazes aprovados entre 1965 e 1992, a pesquisa pública foi responsável por 15 (ANGELL, 2004);

- Das 50 drogas mais vendidas, entre 1992 a 1997, 45 receberam algum fundo governamental em alguma fase de seu desenvolvimento, de acordo com investigação do The Boston Globe. Ao todo, os contribuintes gastaram ao menos US\$ 175 milhões ajudando a desenvolver estas 50 drogas. (DEMBNER, 1998);

- Um estudo de 1998 informa que somente cerca de 15\% dos artigos científicos citados em solicitações de patentes para medicamentos clínicos eram originários de pesquisa realizada pela indústria, enquanto $54 \%$ vinham de centros acadêmicos, $14 \%$ do governo e os demais 17\%, de várias outras instituições públicas e sem fins lucrativos (ZINNER, 2001); 
- Os NIH selecionaram os cinco medicamentos de maior venda em 1995 e concluíram que 16 dos 17 trabalhos científicos que levaram à suas descoberta provinham de fora da indústria farmacêutica (PUBLIC CITIZEN, 2001) ${ }^{25}$.

Para sistematizar o processo de desenvolvimento de novos produtos, ele é dividido em duas etapas: estudos pré-clínicos e estudos clínicos. Nos primeiros, a droga é testada em animais e nos segundos, a droga é testada em seres humanos.

Ao chegar na etapa de estudos clínicos, fica muito difícil a empresa manter sigilo da droga estudada. Por isso, as empresas normalmente patenteiam a droga pesquisada no início desta fase, sendo que o prazo da expiração de sua patente começa a contar a partir desse momento. A empresa detentora da patente tem todo interesse comercial de que os estudos clínicos ocorram o mais rápido possível, afinal, quanto mais tempo gasto nesta etapa da pesquisa, menor será o tempo de usufruto do benefício concedido pela patente.

Indo para os ensaios clínicos, veremos que os mesmos são subdivididos em quatro fases. As três primeiras fases ocorrem antes da aprovação para a comercialização da droga e a última - a fase IV - após essa aprovação. Esta última fase ocorre pretensamente por duas razões: buscar efeitos colaterais desconhecidos (não encontrados nos pequenos grupos de pessoas das três fases anteriores) ou descobrir novos usos para medicamentos já conhecidos. Porém, na opinião de muitos críticos, esta fase não passa de pretexto para que a indústria pague a médicos para prescreverem a seus pacientes algum medicamento já aprovado. Voltaremos a falar um pouco mais sobre esta fase, posteriormente.

${ }^{25} \mathrm{O}$ documento que revela estes dados foi produzido pelos próprios $\mathrm{NIH}$, porém o mesmo não fora publicado. O grupo Public Citizen obteve e publicou estes dados por meio da lei estadunidense de Liberdade de Informação. 


\subsubsection{A Extensão da Vigência das Patentes Existentes}

Para não perder a lucratividade garantida pelas patentes, já que grande quantidade de medicamentos estava próxima de se expirar ${ }^{26}$ e dado que, conforme explicado, os novos produtos não chegariam a tempo de substituir os grandes campeões de vendas, a indústria conseguiu um grupo de leis, conhecidas como a lei Hatch-Waxman, para prorrogar o monopólio dos medicamentos de marca registrada. A intenção deste grupo de leis foi o estímulo à indústria de genéricos, mas os advogados da indústria conseguiram manipular alguns de seus dispositivos para prorrogar a vigência das patentes mais do que o esperado pelos legisladores.

Na década de 90 , outras leis foram aprovadas no sentido de prolongar ainda mais a vigência das patentes.

ANGELL (2004) afirma que "o resultado é que o prazo efetivo das patentes aumentou de oito anos (em 1980) para cerca de quatorze anos (em 2000)".

2.4.3 O Papel que a Indústria Farmacêutica Assumiu: da Imagem em Inovação em Pesquisa à Realidade de uma Empresa Especializada em Marketing e Lobby

A indústria farmacêutica reivindica o posto de "indústria genuinamente inovadora" para justificar seus preços, mas, como demonstrado na seção 1.2.2.3, os medicamentos não são tão inovadores assim e o custo com pesquisa e desenvolvimento é muito inferior ao custo com marketing.

ANGELL (2004), utilizando-se de dados da revista The Fortune 500, de 2002, mostra que nenhum setor tem lucrado tanto quanto a indústria

${ }^{26}$ Seção 2.4 e nota de rodapé número 24. 
farmacêutica. Em 2001, os dez maiores laboratórios estadunidenses ${ }^{27}$ obtiveram o primeiro lugar em retorno sobre as vendas, com $18,5 \%$. O segundo lugar ficou com o setor bancário (agressivo por sua própria natureza) e ainda assim, bem longe, com 13,5\%. O mais espantoso são os lucros destes dez laboratórios que somados (US\$ 35,9 bilhões) superam todas as outras 490 empresas juntas (US\$ 33,7 bilhões). Ou seja, nas palavras de ANGELL (2004), "quando afirmo que essa é uma indústria lucrativa, quero dizer, lucrativa de verdade".

A indústria farmacêutica transformou-se numa grande empresa de lobby e de marketing. Não precisando preocupar-se com pesquisa, basta a ela manobrar as políticas públicas que lhe garantam o monopólio patenteário e conduzam os profissionais de saúde e o consumidor a acreditar que o seu medicamento é a melhor solução para o seu problema.

Para isto, é necessário manobrar a idéia da concepção de remédio, que se dá através da idealização de "medicamento genuinamente inovador", conforme descrito na seção 2.4.1, ou manobrar a idéia de problema, utilizando-se dos mecanismos descritos em todo o capítulo 2.

ANGELL (2004) conclui que a indústria farmacêutica, ao invés de ser uma história de sucesso do livre mercado, como esta indústria se coloca, na verdade e num outro extremo, é uma história de direitos de monopólio e de dependência às pesquisas financiadas pelo governo.

\footnotetext{
${ }^{27}$ A revista The fortune 500 refere-se apenas a empresas estadunidenses. Isto significa que as dez maiores empresas farmacêuticas que ela se refere, não são necessariamente as dez maiores empresas farmacêuticas do mundo, porque não está se considerando os laboratórios farmacêuticos europeus. Ou seja, certamente há um volume muito maior de dinheiro em questão se considerarmos todas as gigantes do mundo.
} 


\title{
2.5 CASOS DISCUTIDOS NO DEBATE SOBRE A MERCANTILIZAÇÃO DA DOENÇA
}

\begin{abstract}
Dissertaremos sobre alguns casos discutidos no debate sobre a mercantilização da doença. Estes casos foram extraídos de artigos ou trechos de livros e seu autor está indicado no início de cada subseção. Os casos ilustram e demonstram como as doenças/condições inseridas nesse debate trabalham com as concepções e estratégias descritas pelos autores citados desde o início deste capítulo.
\end{abstract}

\subsubsection{O Primeiro Caso Histórico Recente - A Halitose (DOSSEY,} 2006)

Em 1865, o cirurgião inglês Joseph Lister desenvolveu o primeiro procedimento de antisepsia cirúrgica. Basicamente, o método era a pulverização de uma solução de ácido carbólico (um fenol) nos instrumentos cirúrgicos, nas roupas, no ar e na incisão cirúrgica, sendo que o cirurgião deveria utilizar luvas e lavar suas mãos na solução de ácido carbólico antes e depois da cirurgia. Lister foi reconhecido como o pai da moderna antisepsia e honrado com a adoção no nome Listeria para um gênero de bactérias patogênicas.

Outra honra concedida a Lister ocorreu quando os Drs Joseph Lawrence e Jordan W. Lambert, em 1879, colocaram no mercado um antiséptico cirúrgico o qual foi dado o nome "Listerine". Inicialmente, o produto fora utilizado para antisepsia de salas cirúrgicas, limpeza de chão e até tratamento de gonorréias. Em 1895, o seu uso foi direcionado para tratamentos dentários feitos por dentistas e, em 1914, tornou-se o primeiro 
enxaquatório bucal a ser encontrado nas prateleiras de estabelecimentos comerciais dos Estados Unidos.

Nos anos 20, a Lambert Pharmacal Company, fabricante do Listerine, havia achado uma cura. Faltava achar a doença. O publicitário Gordon Seagrove foi contratado para promover o produto e, ao ouvir a descrição do produto e seus usos em uma reunião, tomou conhecimento do termo halitose e aprendeu seu significado: "hálito desagradável".

Até então, a halitose era um termo médico obscuro que quase ninguém tinha ouvido falar. Os publicitários tiveram a idéia de promover 0 Listerine como a cura para esta condição, a qual, propagavam eles, "arruinava qualquer chance de romance, casamento e emprego". Logo, pessoas de todo os Estados Unidos estavam sofrendo de halitose.

Um anúncio retratava uma bela mulher sentada num sofá brincando com seus cãezinhos seguido da seguinte legenda "o que ela realmente queria, era ter filhos". O anúncio implicava que a razão para ela estar com cãezinhos (e não com filhos) é que ela não usava Listerine para sua halitose. Outro anúncio mostrava uma mulher glamorosa angustiada em vestes de noite "Eu era uma caronista na estrada do amor" até, é claro, ela começar a utilizar Listerine. As propagandas de Listerine também buscavam o público masculino. Um anúncio mostrava uma noiva que se perguntava: "eu serei feliz a despeito disso?" (referindo-se ao noivo com halitose). Em outro, um homem acabava de ser demitido e segurava seu último contra-cheque e o anúncio perguntava "Você teria Ihe dito a verdade?" (atribuindo a halitose o motivo de sua demissão).

O acadêmico da área publicitária James B. Twitchell, disse que "Listerine não fez um enxaquatório bucal tanto quanto fez a halitose". Promover a halitose funcionou espetacularmente. As vendas subiram de US\$ 115.000 para mais de oito milhões de dólares em sete anos. O sucesso de Listerine influenciou a publicidade estadunidense. Com este tipo de promoção, homens começaram a identificar inquietações e ansiedades pessoais que poderiam ser abolidos por produtos específicos. Um conceito na área da propaganda diz que "anúncios ajudam a manter as massas 
insatisfeitas com seu modo de vida, descontentes com coisas ruins a sua volta; consumidores satisfeitos não são tão úteis quanto os insatisfeitos".

Como exemplo, em 1919, uma companhia, Odo-Ro-No, que fabricava um desodorante feminino de mesmo nome, utilizou a mesma estratégia de Listerine. Enquanto a maioria das propagandas de desodorantes daquela época apelavam para a elegância e a delicadeza da usuária feminina, OdoRo-No descaradamente impelia as mulheres a realizarem o "Teste de odor das axilas". A reprovação neste teste indicava que elas estavam sofrendo de "B.O.". Esta foi a primeira empresa a utilizar o termo "B.O." em uma propaganda. Atualmente, o termo é admitido como algo delicado, mas na época, não. B.O. significava, mas não dizia abertamente, "odor do corpo" (body odor).

Segundo DOSSEY (2006) o truque é exagerar sobre uma condição comum do dia-a-dia até atingir o nível de patologia, a qual, se não atendida, pode frustrar a perspectiva de felicidade e sucesso das pessoas.

\subsubsection{O Colesterol (MOYNIHAN e CASSELS, 2005)}

Os medicamentos para baixar o colesterol é a categoria de medicamentos mais vendida do mundo.

Como grupo, vendem US\$ 25 bilhões por ano, incluindo a venda de empresas como Bayer (alemã), AstraZeneca (anglo-suéca) e Pfizer (EUA).

O colesterol faz parte da composição natural do corpo humano. Porém, há evidências científicas que um alto nível de colesterol no sangue aumenta o risco de ataques cardíacos e derrame. Esse aspecto é apenas um dos fatores, no entanto, as pessoas não tem certeza do risco real que correm ao considerar, isoladamente, uma alta taxa de colesterol.

O professor Shah Ebrahim, pesquisador inglês, concorda que as novas drogas (estatinas) são importantes em casos de pessoas que já tiveram doenças do coração, mas defende que estratégias já bem 
conhecidas como ter uma dieta equilibrada, fazer exercícios regularmente e parar de fumar são suficientes para a maioria dos casos.

As estatinas são drogas que devem ser utilizadas com muito rigor, pois há histórico nesta família de drogas que relata possíveis complicações conseqüentes de sua utilização, como no caso da estatina Baycol (Bayer), que saiu do mercado após estar implicada em diversos casos de morte. A estatina Crestor da AstraZeneca recebeu várias solicitações para sua retirada do mercado devido aos efeitos colaterais raros, mas debilitantes, como desgaste muscular e deficiência renal.

Drogas que atuam em outros sítios de ação para baixar os níveis de colesterol continuam sendo pesquisadas como o torcetropib, o qual a Pfizer precisou paralisar os testes clínicos devido à morte de 82 pacientes nas pesquisas envolvendo este medicamento.

O início desta nova "doença" ocorreu em 1987, quando a Merck lançou a estatina Mevacor aprovada para baixar os níveis de colesterol. Isso significou a possibilidade de medicar pessoas saudáveis.

Atualmente, o medicamento Lipitor comanda metade deste mercado, com vendas de quase US\$13 bilhões anuais. É o medicamento mais vendido até então. A fabricante do Lipitor, Pfizer, sediada em Manhattan, é a maior indústria farmacêutica do mundo e uma das maiores corporações mundiais com faturamento de aproximadamente US $\$ 200$ bilhões de dólares anuais.

As vendas dessas drogas aumentaram na última década, devido a grande inclusão de pessoas definidas como pessoas com "colesterol alto". O consenso do que se pode considerar como "colesterol alto" tem sido constantemente redefinido de forma a incluir cada vez mais pessoas nesta categoria. Nos anos 90, de acordo com as diretrizes dos Institutos de Saúde dos EUA, 13 milhões de americanos estavam incluídos no grupo daqueles considerados com "colesterol alto", justificando o uso de medicamentos. Em 2001, houve uma redefinição do consenso que reduziu muito o nível na classificação do que seria "colesterol alto", incluindo milhões de pessoas neste grupo, triplicando o número daqueles que poderiam ser tratados com 
medicamentos. Este consenso, reescrito em 2001, incluiu 36 milhões de americanos nessa categoria. Dos quatorze autores do novo consenso "expandido", cinco (entre eles, o presidente do comitê) tinham ligações financeiras com os fabricantes de estatinas.

Em 2004, uma nova revisão foi feita, o que aumentou para 40 milhões de americanos com níveis altos de colesterol. Novamente, oito dos nove autores da revisão ou eram palestrantes patrocinados, consultores ou pesquisadores de empresas fabricantes de medicamentos desta categoria. Os conflitos de interesse não foram inicialmente públicos até organizações de mídia denunciá-los. Embora se possa argumentar que a existência de patrocínios não signifique, obrigatoriamente, a implicação de tendências nestes consensos, o fato destes não serem públicos aumenta a percepção da existência destes conflitos de interesse.

O exemplo do colesterol pode-se estender a outras condições. Estima-se que $90 \%$ daqueles que definem os consensos possuem conflitos de interesses com a indústria farmacêutica.

\subsubsection{A Depressão (MOYNIHAN e CASSELS, 2005)}

Por quase duas décadas a maior estratégia era vender a depressão sob certo ponto de vista. De que ela se deve a um desequilíbrio químico no cérebro, reajustado por um grupo de drogas inibidoras de recaptação de serotonina. Drogas estas que incluem Prozac, Paxil e Zoloft. As vendas triplicaram nos anos 90, gerando vendas de mais de US\$20 bilhões e elevando a categoria entre os medicamentos mais vendidos do mundo.

A deficiência de serotonina é uma entre várias causas científicas da depressão, mas ela é diariamente e massivamente reforçada pela mercadização ${ }^{28}$ farmacêutica.

${ }^{28}$ Mercadização como tradução de marketing, como explicado na $17^{\text {a }}$ nota de rodapé. 
No caso dos novos antidepressivos, os benefícios tem sido mais modestos e os riscos mais sérios do que divulgado nesta década de promoção. De acordo com análises independentes dos estudos clínicos (a maioria deles realizados pelos fabricantes), a média de vantagens destes medicamentos sobre placebo são modestas, com os efeitos colaterais incluindo problemas sexuais, severo desenvolvimento de sintomas maníacos durante a interrupção dos antidepressivos e um aparente aumento de comportamento suicida entre jovens. Ironicamente, uma das indicações destes medicamentos, amplamente divulgado pelo marketing das empresas, é o combate ao suicídio entre jovens deprimidos.

A indústria gasta em torno de US\$25 bilhões, anualmente, em promoção, sendo os representantes de vendas e as amostras grátis os principais componentes destes gastos. Rosquinhas, banquetes e hotéis cinco estrelas são o meio de atingir os médicos e líderes de opinião.

Michael Oldani, um antigo representante da indústria farmacêutica, atualmente PhD em antropologia em Princenton, afirma que "os representantes são mestres em estabelecer crenças, forjar alianças e conseguir comprometimentos através da troca de informações". Ele entende que o ser humano tem a tendência de pagar as gentilezas que lhe são feitas e a melhor forma dos médicos fazerem isso é prescrevendo os medicamentos sugeridos pelos representantes que os visitam. Pesquisas sugerem que médicos expostos a representantes são mais favoráveis a terapias medicamentosas do que não-medicamentosas, como num mecanismo dose-resposta.

Para se ter uma idéia da extensão da influência da indústria sobre a categoria médica, a Associação Psiquiátrica Americana (APA) realiza seu congresso anual em Manhattan, onde milhares de psiquiatras são levados a um verdadeiro espetáculo da indústria farmacêutica, com diversas e gigantescas propagandas (a principal, do medicamento Zoloft, da Pfizer). Eles formam grandes filas para preencher fichas para sorteios de pequenos prêmios, como pontadoras laser, onde são cercados por eficientes representantes de vendas que os fazem se sentir à vontade. 
Esta relação tem sido tão notória que no artigo editorial "Is academic medicine for sale?" do New England Journal of Medicine de 2000, a editora Márcia Angell relatou a história sobre a procura do jornal por uma psiquiatra independente para escrever uma revisão sobre antidepressivos. $O$ artigo relata a dificuldade desta empreitada, uma vez que em quase todos Estados Unidos, muito poucos psiquiatras não possuíam alguma ligação financeira com a indústria farmacêutica. Esta experiência ilustra bem a magnitude do círculo de influência da indústria.

\subsubsection{A Disfunção Erétil [DE] (LEXCHIN, 2006)}

O Viagra, da Pfizer, um medicamento eficaz para a disfunção erétil devido a problemas médicos, como diabete, ou a problemas físicos, como injúrias ocorridas na espinha dorsal, tem sido amplamente divulgado de forma a alterar a percepção de seu uso e ampliá-lo a homens "sadios" com a finalidade de aumentar a habilidade em atingir a ereção e mantê-la por um longo período.

As estratégias utilizadas pela Pfizer para a divulgação do Viagra levam a crer que ela busca um mercado muito maior (quase todos os homens), ao invés de relegá-lo ao nicho daqueles que efetivamente tenham problemas de disfunção erétil devido a problemas orgânicos como a diabetes e a cirurgia de próstata.

O site da Pfizer afirma que "mais da metade dos homens com mais de quarenta anos têm dificuldades de conseguir ou manter a ereção". Não há referência clara para esta informação. Possivelmente, a Pfizer baseou-se num estudo realizado com homens entre 40 e 70 anos, em Massachussets, entre 1987 e 1989. Este estudo extrapolou os resultados para argumentar que $52 \%$ de todos homens dos EUA sofrem de DE (em torno de 18 milhões de americanos, em 1990). Entretanto, este número tem que ser visto em detalhes. 
Primeiro: o estudo contou com dois grupos diferentes. Um maior, que respondeu a nove questões sobre atividades sexuais. E um menor, que respondeu as mesmas questões e mais uma questão adicional, na qual eles deveriam se auto-avaliar em cinco níveis de impotência (desde não impotente até completamente impotente). A resposta do segundo grupo foi extrapolada para o primeiro.

Segundo: o primeiro foi randomizado e o segundo, formado por homens que voluntariamente se apresentaram no centro de urologia clínico universitário. Pessoas que se apresentam a um serviço têm maior probabilidade de ter algum sintoma relacionado àquele serviço, o que enviesa a distribuição do estudo.

Terceiro: ainda que o escore de um grupo pudesse ser extrapolado para o outro, a figura de $52 \%$ ainda é exagerada porque não considerou a divisão etária. O resultado era que $40 \%$ dos homens com mais de 40 anos tinham algum problema com DE, incluindo $17 \%$ classificados como "minimamente impotente", ao passo que, na faixa etária dos maiores de 70 anos, $67 \%$ eram classificados como impotentes.

Além disto, outros estudos não conferem com estes números. Uma análise realizada, em 1999, pela US National Health and Social Life Survey, aponta $18 \%$ dos homens na faixa etária entre 50 a 59 anos com queixas a respeito de manterem a ereção. Outro levantamento, na Holanda, indicou que apenas $1 \%$ de homens entre 50 a 65 anos tem completa inabilidade para atingir a ereção e apenas a faixa dos 70 a 78 anos tinham índices como os do estudo de Massachussets. Cerca de 13 estudos de prevalência de DE foram publicados até junho de 1998, sendo que o de Massachussets foi o que tinha os maiores índices de DE.

Estima-se que a Pfizer gastou cerca de US\$ 303 milhões entre 1999 e 2001 com promoção direta ao consumidor, além da propaganda médica. A propaganda de lançamento do Viagra, veiculada na televisão dos EUA, utilizou-se do ex-candidato à presidência dos EUA (em 1996), Bob Dole. Para associar o Viagra a algo viril, como o esporte, a Pfizer patrocinou a corrida de Nascar, contratou o jogador de beisebol Rafael Pinheiro (que 
tinha 39 anos na época da campanha), trabalhou em conjunto com a revista "Sports Illustrated" e, no Brasil, teve como garoto-propaganda o ex-jogador Edson Arantes do Nascimento, o Pelé.

Entre 1998 e 2002, o maior crescimento do Viagra ocorreu no grupo de homens entre 18 a 45 anos e apenas um terço teriam uma possível causa etiológica para sua utilização.

A possibilidade de uso expandido do Viagra está tão popular, nos EUA, que companhias de seguro-saúde estão se recusando a pagar por ele. Uma delas, a Kaiser Permanente, com nove milhões de membros, estimou que, se tiver que custear o tratamento dos seus associados com Viagra, o gasto será aproximadamente US\$100 milhões anuais.

Uma importante questão na saúde pública é a possibilidade dos medicamentos tratarem o que, até recentemente, era considerado como resultado natural da idade ou parte das variantes emocionais intrínsecas ao ser humano. Há, por exemplo, drogas para calvície e até timidez. A terapia com fármacos se desvia cada vez mais da busca pelo tratamento de doenças enveredando para estes tipos de tratamentos.

Essa evolução traz dilemas e controvérsias sobre quais são as condições e tratamentos legítimos para aqueles relacionados com as prescrições de medicamentos: é possível definir o que pode ser considerado como "desvio da normalidade" que justifique este ou aquele tipo de tratamento? $\mathrm{E}$ as pessoas que não tem nenhum problema clínico, mas apenas querem se sentir bem? Quem pagará por estas terapias e qual a implicação do uso desses recursos da saúde?

Os medicamentos que personificam estas controvérsias são aqueles considerados como as "drogas para o estilo de vida".

As "drogas para o estilo de vida", do ponto de vista do capital, podem representar um mercado promissor. Pois, os problemas muitas vezes partem de um "fácil" diagnóstico, como a calvície e a obesidade. A manipulação genética, por exemplo, possibilitará nos tornarmos mais altos, mais cabeludos ou melhorar a memória. Ou seja, as possibilidades de ampliação de mercados são infinitas. 
A questão é se aceitaremos as graças de nossas limitações ou é legítimo a procura por soluções tecnológicas a elas? O conceito expandido de saúde, da Organização Mundial de Saúde, como "um estado de completo bem estar físico, mental e social" não estaria sendo colocado em xeque, pois não estaríamos todos buscando este completo bem estar?

Este debate é ainda mais complicado quando não há um igual balanço na forma como nós olhamos estas opções. Um mundo dirigido pelo mercado certamente está voltado para a opção da promoção da procura pelo melhor desempenho, do que 0 aceite das limitações. A propaganda mostrando o homem que não aceita seus problemas, ainda que ocasionais, de ereção é um exemplo de como pressões comerciais podem enviesar o debate.

A conclusão é que, embora o medicamento seja eficaz para aqueles com real necessidade médica ou clínica, ele pode ser usado em uma população muito maior. A campanha da Pfizer de conscientizar (ou divulgar) a população sobre os problemas de DE, carrega implícita a mensagem que estreita a possibilidade do tratamento a apenas uma opção: o medicamento. Assim, a Pfizer consegue transformar o Viagra em um produto de consumo.

\subsubsection{A Hiperatividade (PHILLIPS, 2006)}

Nos últimos vinte anos, o transtorno pelo déficit de atenção / hiperatividade (TDAH) emerge como uma desordem de importância na fase pueril. As prescrições de psicoestimulantes aumentaram a partir dos anos 90. Entre 1990 e 1995, aumentaram cerca de 2,5 vezes nos EUA e 5 vezes no Canadá e, entre 1990 e 2000, nove vezes em New South Wale, na Austrália.

A TDAH junta-se a outras doenças como a dislexia e a OMA serosa, são consideradas significantes, em conseqüência de seus efeitos na performance educacional. Devido a isso, os professores assumem papel 
importante, porque são os primeiros que podem detectar os sinais dessas doenças.

Segundo CONRAD, a partir do momento em que as desordens, inicialmente entendidas como não-médicas, são redefinidas como doenças, as pessoas freqüentemente assumem o papel de disseminadoras dessas "doenças" nas rotinas de suas vidas. No caso do TDAH, os professores assumem um papel além daquele de conscientização dos pais. Eles participam do diagnóstico, sendo potenciais "agenciadores” da doença.

Em um estudo com 491 médicos de Washington, quase metade dos diagnósticos de TDAH foi inicialmente sugerida por professores.

Entendendo esse mecanismo, a indústria se aproximou dos professores utilizando diversas estratégias. Uma delas é a criação de sites "externos" ao site das corporações, contendo recursos específicos a professores. Em um deles, intitulado "se os pais perguntam...", a Novartis fornece respostas que os professores podem dar aos pais. As respostas normalmente sugerem encaminhamento médico e chamam a atenção para a importância do uso dos medicamentos. "TDAH é uma condição séria e pode requerer que a criança utilize medicação..... Os sites incorporam links que direcionam ao site da indústria patrocinadora ou ao site do medicamento desta indústria. Outra estratégia é a atividade de fundações, como a fundação Shire, que possui uma campanha anual de "toll-free" - ligue para um especialista em TDAH. Esta campanha está em seu sétimo ano e um dos seus tópicos de discussão é como manejar a TDAH nas escolas.

Em 1997, a Novartis colaborou com a Associação Nacional das Escolas de Enfermagem, fornecendo kits contendo informações sobre TDAH e seus tratamentos a cerca de onze mil escolas de enfermagem. Mais tarde, a Novartis colaboraria com a Associação Nacional das Escolas de Enfermagem para produzir material sobre 0 uso responsável dos medicamentos psicoestimulantes.

O CHADD (Children and Adults with Attention Déficit / Hiperactivity Disorder) é um grupo em defesa às pessoas com TDAH, nos EUA. No ano financeiro 2004/2005 (fechamento 30/06/05), o balanço do CHADD indicava 
que $22 \%$ dos recursos financeiros deste grupo advinham da indústria farmacêutica. Uma das principais atividades do CHADD é o programa educacional para os professores. O grupo é responsável pelo tópico de TDAH na revista Health in Action, uma publicação trimestral da Associação de Saúde Norte Americana.

$\mathrm{Na}$ Inglaterra, uma outra publicação, a National Attention Déficit Disorder Information and Support Service (ADDISS), tem como um de seus objetivos produzir programas educacionais para professores. Este serviço também recebeu fundos da Janssen-CILAG, UCB Pharma e Eli Lilly.

A GlaxoSmithKline, a Pfizer e a Associação das Indústrias Farmacêuticas da Inglaterra fornecem uma grande gama de materiais educacionais científicos on line para escolas.

A penetração organizada das indústrias farmacêutica no universo escolar é um novo fenômeno e, embora seja possível argumentar que isto é uma ajuda, como pensar que doenças tão importantes como autismo, dislexia e outras condições que impactam na performance educacional, não recebam nenhum tipo de material informativo. Talvez por ainda não possuírem terapias farmacológicas.

\subsubsection{A Disfunção Sexual Feminina [DSF] (TIEFER, 2006)}

A vida sexual tornou-se vulnerável ao fenômeno da "mercantilização" da doença devido a duas razões. Primeiro, em função de uma longa história de controle político e social da expressão sexual, que dificulta o entendimento do que realmente seja isto e qual o significado da satisfação sexual. Segundo, devido à construção de uma cultura popular que inflou as expectativas sobre a função sexual ou a importância do sexo na satisfação pessoal e nos relacionamentos pessoais. Assim, as pessoas foram levadas a esperar grandes recompensas através do sexo sem, no entanto, saber como obtê-las, ficando então vulneráveis às soluções simples e rápidas. 
Abriu-se espaço para introduzir a mercantilização da doença, processo que encoraja a conversão de uma ansiedade construída socialmente em um diagnóstico médico susceptível a um tratamento farmacológico.

Nos anos 80, a partir de novos conhecimentos focados na função sexual, surge uma "medicina sexual", principalmente na área de urologia. São criadas clínicas de tratamento sexual que focavam os problemas de ereção masculina. Em 1992, o consenso nacional dos Institutos de Saúde dos EUA legitimou os trabalhos sobre impotência. Como resultado, foi gerado um documento com trinta e quatro páginas sobre vários aspectos da ereção (para muitos, uma idéia reificada de ereção, como essência da sexualidade masculina). A criação da "disfunção erétil" como uma desordem médica séria, prevalente e passível de ser tratada com medicação ocorre com a aprovação do FDA e o lançamento do Viagra, em março de 1998. Nessa ocasião, não estava claro se e como o Viagra se propunha a tratar a DSF.

Em 1997, urologistas introduzem o termo "disfunção sexual feminina" referindo-se a aspectos da patofisiologia genital, considerada análoga à disfunção erétil.

A linha divisória na DSF foi a Conferência "Cape Cod", em maio de 1997. Com o tema "trabalhos clínicos sobre a avaliação da função sexual", esta conferência foi fortemente patrocinada por indústrias farmacêuticas. A partir daí, iniciou-se uma série de discussões, mas a DSF continuava sem uma definição precisa. A introdução do "International Jounal of Impotence Research", de 1997, fazia referência a esta dificuldade de definir quando termina uma função sexual normal e começa a desordem médica.

Em 1998, Irwin Goldstein, pesquisador da universidade de Boston, abriu a primeira clínica especializada para a saúde sexual feminina e organizou a primeira conferência de DSF ("New perspectives in management of female sexual diysfunction") em Boston, em 1999. Goldstein também é editor da revista "Journal of sexual Medicine", lançada em 2004, que mantém um suplemento sobre DSF, patrocinado pela indústria farmacêutica. 
Uma urologista que trabalhou com Goldstein na universidade de Boston, Jennifer Berman, associou-se com sua irmã, a educadora sexual Laura Berman e elas se tornaram a face da DSF nos EUA. Inicialmente, abriram uma clínica na Universidade de Los Angeles, em 2001, e popularizaram a DSF e também o tratamento off-lable ${ }^{29}$ por medicamentos a partir de programas de televisão (incluindo o talk-show Oprah), websites, publicações de livros e artigos em revistas femininas. Em 2005, as irmãs Berman fecharam a clínica para abrir centros de serviços para a "saúde sexual da mulher", que oferecem avaliações e tratamentos médicos, incluindo serviços como spa e yoga.

A Pfizer foi uma das maiores promotoras da DSF entre 1997 e 2004, quando desistiu da sua busca pela aprovação do Viagra para a DSF, devido à falta de resultados clínicos favoráveis. Um estudo com três mil mulheres não conseguiu demonstrar resultados conclusivos. Apesar disto, o Viagra vem sendo continuamente prescrito e utilizado como off-label para mulheres.

A Procter \& Gamble ( $P \& G)$, gigante indústria de produtos para limpeza, higiene e alimentos, possui apenas cinco medicamentos de prescrição em sua linha de produtos. O seu relatório anual de 2004 informa que o produto Actolnel, aprovado, em 1998, para a doença de Paget e, em 2000, para a osteoporose, tornou-se a marca mais rápida da história da $P \& G$ a fazer um bilhão de dólares. Provavelmente foi este sucesso que encorajou a $P \& G$ investir na pesquisa do produto Intrisa (que atua na cadeia da testosterona), para tratar a "desordem do desejo sexual hipoativo".

Em 2004, a mudança da identidade da DSF para "desordem do desejo sexual hipoativo" demonstram os esforços para a utilização de alguma droga para a DSF, com o constante movimento de sintomas e rótulos. Entretanto, a droga Intrisa não foi aprovada pelo FDA por falta de dados de segurança a longo prazo e de suficiente pesquisa clínica.

\footnotetext{
${ }^{29}$ Uso Off-label é um termo surgido nos EUA. É uma forma de uso regulada pelo FDA, permitindo aos médicos prescrever medicamentos aprovados para outras indicações que não aquelas previstas em sua licença. Disponível em: http://www.medterms.com/script/main/art.asp?articlekey=4622 [Acesso em 03 de maio de 2008]
} 
Apesar disto, o pesquisador de testosterona Jan Shifren, estima que um quinto das prescrições de produtos à base de testosterona e aprovados para homens são prescritos para mulheres como uso off label.

O sucesso da mercantilização da DSF é demonstrado pela forma como atualmente é naturalizada: uma doença passível de tratamentos com medicamentos. Isto, quando ainda nem ao menos se conseguiu definir os limites entre uma função sexual "normal" e uma "anormal", além de todas as dificuldades em definir um conceito claro do que é DSF. Soma-se a isto, a falta de dados clínicos científicos sobre a eficácia e segurança dos medicamentos indicados para esta "doença". Ainda assim, a DSF é largamente divulgada e tratada com medicamentos.

\subsubsection{O Transtorno Bipolar (HEALY, 2006)}

Desde os anos 50, a depressão e a psicose maníaco-depressiva têm sido tratadas, respectivamente, com antidepressivos e antipsicóticos ou lítio. O lítio era o único agente utilizado como profilático em casos de psicose maníaco-depressiva. Porém, o lítio não foi originalmente pensado como um "estabilizador de humor". Este termo, "estabilizador de humor", não era utilizado até 1995, quando o laboratório Abbott conseguiu a licença para utilizar o anticonvulsivante valproato de sódio (Depakote) para tratar o quadro agudo da mania. Após 1995, houve um grande crescimento no uso do termo "estabilizador de humor" nos títulos de artigos científicos. Em 2001, mais de cem artigos destacavam esse termo. Diversas revisões deixam claro que ainda não há consenso do significado do termo entre a comunidade psiquiátrica. Mas esta falta de consenso não impede a mensagem de que pacientes com a desordem bipolar precisam ser detectados e, uma vez detectados, precisam de "estabilizadores de humor" e talvez apenas estas drogas, sem utilização de outros medicamentos. 
As primeiras drogas a colonizar o nicho dos estabilizadores de humor foram os anticonvulsivantes. Os anticonvulsivantes são benéficos para os casos de epilepsia e foram inicialmente utilizados para evitar a reincidência de ataques epiléticos. Nos anos 80, Robert Post sugeriu que os anticonvulsivantes pudessem estabilizar o humor na psicose maníacodepressiva, evitando acessos reincidentes. Esta foi a idéia que municiou a possibilidade do tratamento do transtorno bipolar com medicamentos e, a partir dessa possibilidade, a campanha para divulgar a doença e o tratamento da desordem bipolar foi imensa.

O transtorno bipolar foi incluído na DSM (Diagnsotic and Statistical Manual of Mental Disorder) em 1980. Nesta ocasião, ficou definido o critério para o transtorno bipolar I (doença maníaco-depressiva clássica), caracterizado por apenas um episódio maníaco. Desde então emergiram outras variações do transtorno; o transtorno bipolar II (hipomania associado a pelo menos um episódio depressivo maior), a desordem bipolar SOE (sem outras especificações) e o transtorno ciclotímico. A introdução destas variações aumentou a prevalência do transtorno bipolar de 0,1\% (para a população tendo desordem bipolar I) para 5\% (incluindo todos os transtornos). O que também fez surgir novas instituições interessadas nesta condição.

Os casos agudos de transtornos bipolares são classicamente tratados de forma científica e racional com antipsicóticos. Entretanto, não havia se pensado em utilizá-los de forma profilática. O crescimento de indicadores epidemiológicos de que a prevalência da doença pudesse ser maior que a inicialmente estimada aumentou o interesse acadêmico pelo assunto. Além disso, colocou em marcha os laboratórios Lilly, Janssen e Astra-Zeneca (fabricantes, respectivamente, dos antipsicóticos olanzipina, risperidona e quetiapina) a caminho da utilização destas drogas como forma profilática destas doenças. Isto, por sua vez, motivou outras empresas a atuar neste, por assim dizer, "mercado bipolar". Entretanto, ainda não há consenso que comprove qualquer uma destas três drogas como efetiva no uso profilático, 
extinguindo a propensão de novos ataques daqueles pacientes com 0 transtorno bipolar, diferentemente da utilização nos estados agudos.

Com a expansão das estimativas de prevalência dos transtornos bipolares, surgiram novos informativos ("Bipolar Disorders" e o "Journal of Bipolar Disorders"), várias sociedades de pacientes, conferências anuais (muitas delas, fortemente financiadas pelas companhias farmacêuticas) e novos websites sobre o tema, normalmente enfatizando que a vida dos usuários contínuos dessa medicação é melhor do que aquelas que não utilizam.

Há, entretanto, poucas evidências para o uso profilático de medicamentos como tratamento para a psicose maníaco-depressiva (bipolar I). E quase não há evidências que amparam esta utilização no caso das outras variações do transtorno (bipolar II, bipolar SOE e ciclotímico).

Com a possível exceção do lítio para o transtorno bipolar I, não há ensaios randomizados controlados demonstrando, a longo prazo, que pacientes com qualquer um dos transtornos bipolares que receberam psicotrópicos possuam vantagens comparados àqueles que não os receberam. Isso se explica, em parte, devido às dificuldades na condução de ensaios com drogas psicotrópicas por um período maior que algumas semanas em condições tão complexas como a psicose maníaco-depressiva. Uma única pesquisa controlada, randomizada, com placebo e de curta duração (48 semanas), tem sido utilizada como base para alegação que o olanzapine possa ser utilizado como profilático no transtorno bipolar. Até mesmo no caso do lítio, em que as evidências originam-se a partir de amplos estudos abertos (quiçá, melhores até que os estudos randomizados), há alguma discussão sobre o que tem sido demonstrado.

Esta evidência de benefício pelo lítio e do possível benefício pelo olanzapine, deve ser ainda pesada contra dois danos associados com o uso de psicóticos: uma consistente documentação indicando que tratamentos regulares com antipsicóticos aumentam a mortalidade e resultados nos ensaios placebo-controle com antipsicóticos em esquizofrenia que demonstram um excesso estatístico e significante de suicídios. Além disso, 
vários problemas associados a antipsicóticos, desde 0 aumento de mortalidade até a discinesia tardia, nunca aparecem em estudos de curta duração.

Além dos aspectos relacionados aos riscos, é preciso considerar a efetividade terapêutica dos tratamentos no transtorno bipolar. Se a utilização destes medicamentos possui efetividade, então o número de internações por transtorno bipolar deveria ser reduzido. Uma experiência em North Wales mostrou que antes do advento destas "novas farmacoterapias", havia um histórico de quatro internações de pacientes com transtorno bipolar I a cada dez anos. Em contraste, o número de internações quadruplicou a partir da utilização das últimas drogas psicotrópicas. Normalmente, isto ocorre quando o tratamento, ao invés de funcionar, tem outros tipos de efeitos não desejados.

A venda do transtorno bipolar utiliza-se, ainda, da idéia que atribui um alto risco de suicídio a todos os tipos de transtornos.

Os suicídios relacionados ao uso de antidepressivos têm, de forma controversa, outorgado estes fatos a erros de diagnósticos. Afinal, para este argumento, se o médico diagnosticou que o paciente era bipolar, ele não teria como não prescrever um antidepressivo, pois o risco de suicídio, tradicionalmente relacionado a pacientes com um dos transtornos bipolar, dificilmente faria um médico deixar de prescrever medicação a essa pessoa.

Todavia, até o momento, a melhor evidência disponível mostra que pacientes não medicados com desordem bipolar não possuem altos riscos de suicídio. STOROSUM (2005, apud HEALY, 2006) e seus colegas analisaram todos os estudos randomizados duplo-cego, placebo-controle dos estabilizadores de humor para a prevenção da psicose maníacodepressivo utilizados no dossiê para registro, submetido ao órgão regulatório da Holanda, o Medicine Evaluation Board, entre 1997 e 2003. Eles encontraram quatro estudos sobre profilaxia. Eles compararam o risco de suicídio em pacientes com placebo contra aqueles com a droga ativa. Dois suicídios (493/100.000 pessoas-ano de exposição) e oito tentativas de suicídios (1.969/100.000 pessoas-ano de exposição) ocorreram no grupo 
que recebeu a droga ativa (943 pacientes), mas nenhum suicídio e duas tentativas de suicídios (1.467/100.000 pessoas-ano de exposição) ocorreram no grupo placebo (418 pacientes). Baseado nos números absolutos destes quatro estudos foi calculado que, com as drogas ativas, o risco de suicídio é 2,22 vezes maior do que com o placebo.

O conhecimento clínico recente apontava como muito raro um ataque maníaco-depressivo antes da adolescência. A partir dos anos 2000, surge um novo diagnóstico do transtorno bipolar nas crianças dos EUA, embora estas crianças não atendam a todos os critérios para o transtorno bipolar I (critérios segundo o Diagnostic and Statistical Manual of Mental Disorders). Contudo, o transtorno bipolar pediátrico foi capa da revista Time, em agosto de 2002, destacando uma criança com nove anos com a desordem. Um livro publicado nos EUA em 2000, intitulado The bipolar child, vendeu 70 mil cópias em seis meses. Atualmente, drogas como Zyprexa e Risperidal são utilizadas em crianças pré-escolares, nos EUA, com muito pouco questionamento sobre este novo procedimento.

\subsubsection{A Síndrome das Pernas Inquietas [SPI] (WOLOSHIN e} SCHWARTZ, 2006)

Em 2003, a GlaxoSmithKline iniciou a campanha de divulgação de uma nova síndrome, a "síndrome das pernas inquietas". Primeiramente, divulgando apresentações realizadas em reuniões na academia americana de neurologia sobre os estudos prévios da droga ropinirole (inicialmente aprovada para a doença de Parkinson) para o tratamento de uma nova síndrome, a SPI. Meses mais tarde, a GSK divulgou à mídia que "novos levantamentos indicavam que a nova e pouco reconhecida desordem, a SPI, estava impedindo americanos de dormir durante a noite". Estes levantamentos foram feitos a partir de um estudo patrocinado internamente e não publicado. Em 2005, o FDA aprovou o ropinirole para o tratamento da 
SPI - esta foi a primeira droga aprovada especificamente para este fim. Desde então, uma campanha multimilionária de divulgação da SPI foi deflagrada para atingir médicos e consumidores.

Um levantamento, com artigos publicados entre novembro de 2003 a novembro de 2005, excluindo aqueles que não se referiam diretamente a SPI (desconsiderados, por exemplo, artigos sobre transtornos durante o sono que apenas mencionavam a SPI), selecionou e analisou 33 artigos que se referiam especificamente a SPI. Este levantamento pôde classificar os 33 artigos em pelo menos um dos três elementos chaves que o autor considerou como estratégias para a mercantilização da doença: (1) superestimando a prevalência da doença, (2) encorajando a realização de mais diagnósticos, (3) sugerindo que todas as doenças possam ser tratadas com medicamentos.

Quase dois terços dos artigos superestimaram a prevalência da doença - muitos diziam que "quase 12 milhões de americanos sofrem com esta síndrome" ou "ela afeta um entre dez adultos nos EUA" - nenhum destes artigos questionavam a validade das estimativas em que eles se baseavam. Há motivos para suspeitar desses números. Existem quatro critérios para detectar esta síndrome. O estudo sobre os artigos que indicavam a estimativa de quase $10 \%$ da população adulta com a síndrome fez apenas uma pergunta para identificar a SPI. Desconsiderando os outros critérios, ele incluiu pessoas com outras possíveis causas (como, por exemplo, problemas musculares e neuropatias diabéticas) no grupo daqueles com SPI, o que, conseqüentemente, inflou as estimativas.

Num estudo recente e mais amplo, apenas $7 \%$ dos pesquisados atendiam a todos os quatro critérios do diagnóstico, sendo que somente $2,7 \%$ apresentaram sintomas moderados ou severos de angústia duas ou mais vezes por semana. Podemos considerar que mesmo este 2,7\% é ainda provavelmente alto, pois o estudo foi enviesado na amostragem, uma vez que $98 \%$ dos participantes concordaram em participar de um estudo sobre pernas inquietas. Pessoas que respondem que concordam com um estudo específico tem maior chance de ter problemas relacionados (no caso, com 
alguma síndrome nas pernas) do que aqueles que não concordam ou desconhecem a natureza do estudo.

Os artigos também reforçaram a necessidade de mais diagnósticos. Cerca de metade deles reportaram uma "síndrome da sub-diagnose" pelos médicos, alegando que pouquíssimos médicos sabem sobre a SPI, sendo ela a "síndrome menos conhecida por eles" e também "desconhecida pelos pacientes", que provavelmente "sofrem em silêncio há anos". Um quarto dos artigos encorajaram os pacientes a se auto-diagnosticarem e sugeriam perguntar a seus médicos se a SPI poderia explicar as causas de vários problemas (insônia, fadiga diurna, desordem ao déficit de atenção nas crianças e depressão). Um quinto dos artigos recomendavam os leitores a procurar a entidade "sem fins lucrativos" Restless Legs Foundation. Os artigos não mencionavam que esta é uma entidade fortemente subsidiada pela GlaxoSmithKline. Nenhum artigo mencionava uma possível "sobrediagnose".

Cerca de metade dos artigos mencionava a droga ropinirole pelo nome. Apenas um quantificava de maneira objetiva os benefícios da droga. Cerca de metade referia-se a pacientes que utilizaram a medicação e que, na maioria dos casos, perceberam grande melhoria. Um terço dos artigos utilizavam o termo "milagroso" para os efeitos da droga.

O fato é que o atual benefício do medicamento é modesto. No produto há a informação de que um estudo conduzido em 12 semanas, nos EUA, verificou que $73 \%$ entre aqueles que tomaram a droga apresentaram melhorias, comparado com $57 \%$ dos que tomaram placebo. Além disso, os efeitos colaterais incluem náuseas $(40 \%$ dos que tomaram a droga versus $8 \%$ com placebo) e vertigens (11\% comparado com $5 \%$, respectivamente). Sonolência e fadiga também ocorreram com mais freqüência com ropinirole do que com o placebo (12\% versus $6 \%$ e $8 \%$ versus $4 \%$, respectivamente).

Apesar disso, apenas 15 artigos mencionavam que o ropinirole poderia ter efeitos colaterais e em apenas um eles foram quantificados. Apenas um artigo mencionava que os estudos eram relativamente curtos em 
sua duração (o mais duradouro, estendeu-se por 36 semanas), a despeito das pessoas poderem utilizar a droga por anos ou durante toda sua vida.

Aparentemente, a mídia é cooptada no processo de "mercantilização da doença". Não é muito improvável que outras doenças estão sendo divulgadas nos moldes da síndrome das pernas inquietas. Afinal, as histórias que promovem as doenças são cheias de drama, como grandes crises de saúde pública ainda não reconhecidas e passíveis de serem resolvidas através de curas miraculosas a curto prazo. 


\section{A MEDICALIZAÇÃO E A RACIONALIDADE TÉCNICA}

"- Você vai derramar cerveja no sofá.

- E daí? É só um sofá.

- É um sofá de US\$4.000,00, estofado em seda italiana! Não é só um sofá!

- Isso é só um sofá! Isso não é vida! São apenas coisas

e são mais importantes para você do que viver! Isso é loucura!"

(Discussão entre o casal protagonista do filme Beleza Americana. EUA. 1999)

Neste capítulo serão apresentados o fenômeno da medicalização e alguns aspectos da constituição da racionalidade técnica, forma hegemônica do pensamento atual, a partir do conceito de fetichismo da mercadoria.

KANE RACED (2006) estabeleceu que a mercantilização da doença combina dois aspectos da vida contemporânea: a patologização e a comodificação ${ }^{30}$. Esses dois aspectos serão estudados neste capítulo.

Partindo da idéia que patologização e medicalização são conceitos muito próximos e que, segundo MOYNIHAN e col. (2002), "algumas formas de medicalizar a vida ordinária agora podem ser melhores descritas como mercantilização da doença: a extensão dos limites da doença para expandir os mercados de novos produtos", a primeira seção deste capitulo será dedicada a introduzir o tema "medicalização".

A "comodificação" será explorada na segunda seção deste capítulo. Os capítulos um e dois mostraram dois fenômenos distintos, cada qual regido por sua lógica: o primeiro, que mostrou o debate sobre o URM, regido pela lógica sanitária e o segundo, que mostrou o debate sobre a mercantilização da doença, regido pela lógica econômica. A diferença entre eles é que o primeiro debate é uma busca, uma tentativa de modificar uma realidade; enquanto que o segundo debate é uma discussão de um fenômeno que está ocorrendo, de uma realidade que se cristaliza. Isto revela

${ }^{30}$ Como visto no capítulo 2 
o predomínio da lógica econômica sobre a lógica sanitária. Este predomínio é determinante para a "comodificação".

Por tratar-se de lógica econômica, a opção deste trabalho foi fazer uma incursão pelos referenciais teóricos que examinam a racionalidade técnica encontradas em Marcuse e Horkheimer. Na raiz dessas formulações, encontram-se o conceito de reificação, de Lukács, e o conceito de fetichismo ${ }^{31}$ da mercadoria, de Marx.

\subsection{O FENÔMENO DA MEDICALIZAÇÃO}

ROZENFELD (1989b) explica que na década de 1970 surgem os trabalhos de Foucault, Illich, Dupuy e Karsenty em que, cada um a sua maneira, enfocou a questão das práticas médicas sob o ângulo das instituições, utilizando o conceito de medicalização das sociedades avançadas, articulando a medicina, a indústria e os medicamentos. Estes autores, segundo ROZENFELD (1989b), destacaram a dependência e a passividade a que são levados os indivíduos em decorrência da medicalização.

Destes autores, vamos adotar o referencial de IVAN ILLICH (1975) e a análise de sua obra feita por TESSER (2006), tendo em vista que, segundo SINGER, CAMPOS \& OLIVEIRA, in BOARINI e YAMAMOTO (2004):

O conceito de medicalização é de autoria de ILLICH (1975), que o usou para descrever a invasão pela medicina de um número cada vez maior de áreas da vida individual: cada etapa da vida humana - desde os recém-nascidos, as crianças, as mulheres grávidas, até os que estão no climatério e os que chegaram à velhice - é hoje objeto de cuidados

\footnotetext{
${ }^{31}$ Fetiche da mercadoria é um conceito desenvolvido por Marx que, como veremos, tem sentido específico. Porém, é interessante observar que a palavra "fetiche" deriva do francês "fétiche", correspondente a "feitiço" em português. Significa objeto animado ou inanimado, feito pelo homem ou produzido pela natureza, ao qual atribui poder sobrenatural e se presta a culto. Fetichismo significa adoração ou culto de fetiche; subserviência total. Novo dicionário Aurélio de Língua Portuguesa. Curitiba: Positivo, 2004.
} 
médicos específicos, independentemente de haver ou não sintomas mórbidos.

TESSER (2006) descreveu que "muito sinteticamente, o processo de medicalização social pode ser visto como a expansão progressiva do campo de intervenção da biomedicina por meio da redefinição de experiências e comportamentos humanos como se fossem problemas médicos".

ILLICH (1975) utiliza o exemplo da dor como ilustrativo da idéia de medicalização. "Ao colonizar uma cultura tradicional, a civilização moderna transforma a experiência da dor. Retira do sofrimento seu significado íntimo e pessoal e transforma a dor em problema técnico". O autor explica que "uma dor vivida somente se constitui sofrimento se estiver integrada a uma cultura". ILLICH (1975), então, rebusca os diversos significados da dor nas culturas antigas, grega, judaica e os antigos cristãos, onde a abordagem analgésica era estranha a estas civilizações européias por três motivos:

- A dor no homem era a manifestação de um universo imperfeito, jamais concebido como simples disfunção mecânica;

- A dor era intrínseca a natureza. O médico que tivesse pretendido eliminar a dor teria desnaturado seu paciente;

- A dor era concebida como experiência da alma, mas de uma alma que estava presente no corpo inteiro. Não existia um mal, fonte da dor, que se distinguisse do mal que era a dor em si mesma. Querer eliminá-la teria equivalido à eliminação do paciente.

Segundo ILLICH (1975), a luta contra a dor começa somente quando Descartes separa o corpo da alma. Ele constrói um modelo de corpo semelhante a uma máquina que pudesse ser reparada por um engenheiro. Leibnitz (apud ILLICH, 1975) resume a nova perspectiva didática ao falar do grande engenheiro do Universo que confeccionou o homem do modo mais 
perfeito possível e que não pode inventar dispositivo melhor para sua conservação que o de lhe fornecer o sentido da dor. TESSER (2006) afirma que no fim do século XIX a dor estava emancipada de todo referencial metafísico. O progresso da nossa civilização tornou-se sinônimo de redução de sofrimento, mediante a tentativa de eliminação ou sedação de dores e sintomas e controle dos riscos e doenças crônicas. O desenvolvimento da faculdade de objetivação da dor é um dos resultados da formação científica do médico.

Em ILLICH (1975), vemos que as culturas tradicionais tornavam o homem responsável por seu comportamento sob o impacto da dor. Mas, agora o tecido de respostas orgânicas, pessoais, emocionais e sociais à dor, propiciado por estas culturas, está em vias de se desfazer (ou já está se desfazendo), "de se transformar em uma demanda geral de gestão técnica das sensações, das experiências e do porvir individuais".

TESSER (2006) analisando ILLICH (1975), conclui:

Em meio medicalizado, a dor perturba e desnorteia a vítima sem que ela tenha outros recursos senão entregar-se ao tratamento médico. A cultura medicalizada deixa o homem desamparado e incompetente, pondo-o nas mãos do trato médico profissional, estranho à compreensão tradicional ou pessoal do doente - às vezes já resquicial - e desagregador das relações entrelaçadoras do homem com sua doença, seu meio, a natureza, seus próximos e com ele mesmo. Assim, a compaixão (fonte de consolo, conforto, distração e esperança) e o conhecimento cultural sobre a saúde (tradicional, popular ou de outras medicinas), de gerações anteriores e do entorno social do doente (fonte de tratamento integrado à cultura e à vida do paciente e dos seus), transformam-se em virtudes obsoletas e muitas vezes, indesejadas.

Sem matriz cultural ou conhecimento que propiciem outra saída, os pacientes aprendem a conceber sua própria dor ou adoecimento como fato clínico objetivo, que pode ser submetido a tratamento "estandardizado". Cresce, assim, um processo cíclico em que o indivíduo aprende a se ver como consumidor de anestesias, sintomáticos, quimioterápicos e cirurgias.

(...) No caso da atenção à saúde, a ação especializada, em vez de promover a autonomia do doente, para que este possa necessitar menos de novas ações heterônomas e melhor usufruir de ações eventuais ou necessárias, destrói a autonomia, reivindicando submissão, alimentando a dependência e a compulsão ao consumo, gerando mais demanda por atenção heterônoma, comprometendo, por fim, a sua própria efetividade e eficácia geral. 
A medicalização pode ser vista, também, como uma alienação do indivíduo com seu próprio corpo, em que relações entre ele e a dor, seu sofrimento, suas angústias, seus males, passam a ser mediados, necessariamente, por um outro. E esse outro, por sua vez, tem seu saber tecido em um sistema racional técnico que objetiva esses males, separandoos do indivíduo.

No mesmo raciocínio da expropriação da dor do indivíduo, ILLICH (1975) fará uma crítica a medicalização como um fenômeno geral, afirmando que a medicalização transformou-se numa ameaça à sociedade pela difusão de três iatrogêneses ${ }^{32}$.

- latrogênese Clínica: que se constitui nos danos ao indivíduo ocasionados pelo uso da tecnologia médica, diagnóstica e terapêutica;

- latrogênese Social: referente ao efeito social danoso do impacto da medicina, gerador de desarmonia entre o indivíduo e seu grupo social, resultando em perda de autonomia na ação e no controle do meio;

- latrogênese Estrutural: quando há a destruição do potencial cultural para lidar autonomamente com boa parte das situações de enfermidade, dor e morte.

Com relação a iatrogênese Clínica, Illich demonstra com dados históricos, que os determinantes para o estado da saúde global de qualquer população obedecem, necessariamente, esta ordem crescente de importância:

\footnotetext{
${ }^{32}$ latrogenia é uma alteração patológica provocada no paciente por tratamento de qualquer tipo. Novo dicionário Aurélio de Língua Portuguesa. Curitiba: Positivo, 2004.
} 
- A alimentação, as condições de habitação e trabalho, a coesão do tecido social e os mecanismos sociais que permitem estabilizar a população;

- A atividade de saneamento, incluindo o tratamento das águas, a fossa séptica e o uso do sabão e de tesouras pelas parteiras;

- Em terceiro lugar, situa-se o impacto do ato médico (ou medicalização) sobre a saúde global.

Com relação a esta última, ILLICH (1975) afirma que "contrariamente ao meio e às técnicas sanitárias não profissionais, os tratamentos médicos consumidos por uma população são uma pequena parte e jamais ligada significativamente à redução do peso da morbidade ou o prolongamento da esperança de vida".

Seguem-se as idéias de medicalização de ILLICH (1975), outros inúmeros autores - não necessariamente concordantes com todas as posições de Illich - que estudaram a sociologia da medicina e, embora com diferentes posições filosóficas e conceituais, concordam ser a medicalização um fenômeno que, ao final de sua equação, traz à sociedade contribuições mais negativas (no sentido de avanços com relação à saúde pública global) do que positivas. ${ }^{33}$

\subsection{A RACIONALIDADE TÉCNICA}

Neste ponto nos parece que está bem claro que a doença, a exemplo da dor, usado por ILLIICH (1975), é uma construção social.

\footnotetext{
${ }^{33}$ É difícil nominar todos os autores dedicados ao estudo da medicalização, dado a grande quantidade de estudiosos ao redor do mundo. Somente autores do Brasil, já citamos, no decorrer desta dissertação Rozenfeld, Cordeiro, Bermudez, Tesser, entre outros, mas poderíamos continuar a extensa lista incluindo Nogueira, Lefevre, etc. O fato é que a questão da medicalização, respeitada as diferenças de concepções filosóficas da academia, tem um ponto em comum: é nefasta à saúde pública.
} 
Uma questão fundamental na mercantilização da doença, como afirma MOYNIHAN e col. (2002), é que "a construção social da doença está sendo substituída pela construção empresarial da doença ${ }^{34 "}$.

Para entender este processo é necessário remeter à base material dos conceitos. Para tanto, este trabalho recorrerá a alguns aspectos da teoria do valor e do fetichismo da mercadoria encontrados em MARX (1985). Embora alguns autores entendam estes conceitos como superados e aplicados apenas à época de Marx, dado que as relações do capital na modernidade já não são as mesmas, um aspecto destes conceitos é fundamental ao nosso ver: a abstração inerente ao conceito de valor de troca. O emprego deste aspecto teórico tem um objetivo bastante específico e muito longe de esgotar seu arcabouço teórico: buscar identificar o sentido do fetichismo da mercadoria e o modo como ele foi desenvolvido dentro das reflexões sobre reificação, racionalidade técnica e planificação de mercado, encontrados em LUKÁCS (2003), HORKHEIMER (1976) e MARCUSE (1967), respectivamente.

Não é demais salientar, também, que a rápida incursão a ser feita pela teoria do valor não é em razão do valor em si, mas sim porque o mesmo é pré-requisito para entender o fetichismo da mercadoria.

\subsubsection{O Valor de Uso e o Valor de Troca}

MARX (1985) conceitua a mercadoria como "um objeto externo, uma coisa, a qual pelas suas propriedades satisfaz necessidades humanas de qualquer espécie. A natureza dessas necessidades, se elas se originam no

\footnotetext{
${ }^{34}$ A citação deste trecho no original é: "The social construction of illness is being replaced by the corporate construction of disease". O autor está lançando uma crítica às empresas que redefinem os parâmetros de doença para vender seus tratamentos. Muito embora possa haver o entendimento de que, ainda que seja sob um viés econômico, esta construção não deixa de ser social, não é arriscado admitir que Moynihan queira enfatizar que, atualmente, o fator mercantil tem sido o maior determinante, ou até mesmo, o fator hegemônico, na construção social da doença.
} 
estômago ou na fantasia, não altera nada na coisa"35. O autor elabora o duplo ponto de vista a ser encarado na mercadoria: a qualidade e a quantidade e, como conseqüência direta, estabelece os conceitos de valor de uso e de valor de troca ${ }^{36}$.

Em MARX (1985), a qualidade (ou utilidade) da coisa faz dela valor de uso. Depende exclusivamente das propriedades do corpo da coisa. O valor de uso realiza-se no uso e no consumo. Não depende da quantidade de trabalho para se obter esta coisa.

O valor de troca aparece, inicialmente, como a relação quantitativa na qual o valor de uso de uma espécie se troca com o valor de uso de outra espécie. Ao fazer com que duas mercadorias, de valores de uso distintos, se equivalham, independente da proporção de cada uma para isto, pode-se supor que ambas são redutíveis a um valor comum, a um terceiro, que é o valor de troca. A propriedade do valor de troca encontra-se, então, na "abstração do valor de uso que caracteriza a relação de troca" ${ }^{37}$.

O valor de uso não importa para a formação do valor de troca da mercadoria; a única característica comum entre as mercadorias para a formação de seu valor de troca é o fato das mesmas serem produtos do trabalho. Se o valor de uso não importa para a formação do valor de troca da mercadoria, então o trabalho qualitativo, específico, deixa de ser diferenciador para a formação do valor de troca, reduzindo então todos os trabalhos, a "trabalhos abstratos"38.

O valor de troca só surge quando o valor de uso é transferido para outro através da troca. $O$ valor de troca é a cristalização desta substância social, o "trabalho humano abstrato". O seu "quantum" é a quantidade de trabalho despendida para produzi-lo ${ }^{39}$.

\footnotetext{
${ }^{35}$ Marx, Karl. 0 Capital: crítica da economia política. $2^{\underline{a}}$ ed., São Paulo: Nova Cultural, 1985. p. 45. Observação: o primeiro volume do Capital foi lançado na Alemanha, em 1867.

${ }^{36}$ Ibidem. p. $45-46$.

37 Ibidem. p. $46-47$.

${ }^{38}$ Ibidem. p. 47.

${ }^{39}$ Ibidem. p. 48.
} 


\subsubsection{O Caráter Fetichista da Mercadoria}

As matérias naturais são modificadas pela força de trabalho humano e transformadas em coisas úteis. A madeira se transforma em mesa. Embora a mesa ainda seja madeira, ao ser transformada em mercadoria, ela se transforma em coisa metafísica ${ }^{40}$.

A força de trabalho pode ser comparada, objetivamente, por meio dos produtos do trabalho. Os diferentes produtos condensam, ou reduzem, o valor da força de trabalho quando comparados. Assim, os produtos ao serem transformados em mercadorias, em produtos para troca, servem de meio de valoração, comparação, dos diferentes trabalhos.

As mercadorias refletem aos homens as características sociais do seu próprio trabalho. Objetos de uso se tornam mercadorias apenas por serem produtos de trabalho privados, exercidos independente uns dos outros. As características sociais do trabalho só aparecem mediante a troca de mercadoria.

Apenas na troca, os produtos recebem uma objetividade de valor socialmente igual, separada da sua objetividade de uso, fisicamente diferente. A troca toma tal extensão e importância para se produzir coisas úteis, nas quais o caráter do valor já é considerado na produção dos produtos $^{41}$.

Há um duplo caráter social no trabalho privado:

- satisfazer determinada necessidade social e

- satisfazer a necessidade do produtor ao ser permutável por qualquer outro trabalho.

\footnotetext{
${ }^{40}$ lbidem. p. 70.

${ }^{41}$ Ibidem. p. 71.
} 
Os homens relacionam os produtos de seu trabalho não como envoltórios materiais de seu trabalho humano. Ao comparar os valores de seus produtos, estão comparando seus diferentes trabalhos sem o saber. A determinação dos objetos de uso como valores é o produto social do homem. Como o idioma que falamos. Por ser um produto social vem mascarado como uma forma natural. O valor age com um hieróglifo social.

No mundo de troca dos produtos a questão mais importante é quantos produtos alheios recebe-se em troca de determinado produto.

O caráter de valor dos produtos de trabalho apenas se consolida mediante sua efetivação como grandeza de valor. As grandezas de valor variam sempre independente da vontade, da previsão e da ação dos que trocam.

Os trabalhos privados independentes, mas universalmente interdependentes, têm como lei (naturalizada) reguladora das relações de troca, o tempo de trabalho socialmente necessário.

A reflexão sobre as formas de vida humana e, portanto, sua análise científica, segue, sobretudo, um caminho oposto ao desenvolvimento real, ocorre após esta própria forma de vida. A certificação do produto do trabalho como mercadoria já possui a estabilidade de forma natural da vida social. Não se reconhece o caráter histórico dessas formas sociais considerada como imutável, nem tampouco seu conteúdo. Assim, o fato de somente a expressão monetária fixar o caráter do valor da mercadoria, vela o caráter social dos trabalhos privados ${ }^{42}$.

COHEN (1978) explica que o termo fetiche deriva do discurso religioso (investir algo com um poder que ele não tem por si mesmo) e que a o fetiche identificado por MARX (1985) na esfera econômica é parcialmente análogo ao fetiche religioso. Enquanto o fetiche religioso resulta de um processo mental, os fetiches econômicos derivam do processo de produção. O fetiche econômico está intrinsecamente associado à sociedade capitalista, pelo seu princípio de trocas, e tem uma característica fundamental: persiste

${ }^{42}$ Ibidem. p. 73. 
mesmo quando desvendado. Entendê-lo não dissipa o modo místico como a economia de mercado é percebida e funciona.

COHEN (1978) entende que isto ocorre porque o fetiche religioso não possui o poder que aparentemente ele o tem. O fetiche econômico sim. A ilusão consiste no fato de que este poder não é inerente ao produto, mas resultado do trabalho acumulado no mesmo. A forma do valor de troca é visível, mas sua fundação na atividade laboral não o é. A forma social de relação oculta o conteúdo material. O valor de troca parece transcender sua base material no trabalho e derivar da própria mercadoria. O valor de troca é uma propriedade de relação social das mercadorias e o fetichismo oculta a base material como fonte desta propriedade.

Assim, para o autor, há duas fases no fetichismo da mercadoria: a separação do valor de troca de sua base material e o acoplamento do valor de troca na substância mercadoria.

Essa idéia de abstração, de fetichismo, de caráter velado, se torna clara, na medida em que acompanhamos outros teóricos marxistas. O dinheiro, por exemplo, possui um caráter velado característico do mecanismo mercantil. ROSDOLKY (2001), relaciona a criação do dinheiro com o fetiche da mercadoria. Em seu entendimento, o dinheiro é "aquela mercadoria particular que pode ser trocada por qualquer mercadoria”. Mais, ele é aquela mercadoria que é equivalente geral para todas as demais, é a substância universal dos valores de troca. Para tanto, esta mercadoria adquire "existência independente das próprias mercadorias", encarna uma "mercadoria específica". Nas mercadorias, o valor de troca é a sua expressão quantitativa de troca. No dinheiro o valor de troca é o próprio objeto, mas que adquire uma existência autônoma fora do próprio objeto.

As mercadorias, quando comparadas, são objetos que manifestam o valor, e para isto o valor adota a forma das mercadorias. Cria-se a aparência de que as mercadorias possuem, por natureza, uma forma-valor. Essa propriedade torna-se aparentemente natural da mercadoria, como natural, de fato, são propriedades como seu peso, sua textura, etc. Este é o 
fundamento do caráter social do trabalho ser incorporado na relação social entre os produtos do trabalho (troca).

Porém, no caso do dinheiro, essa reificação adquire forma bem definida, pois todas as mercadorias passam a expressar seu valor no mesmo equivalente, na mesma mercadoria-dinheiro. Consolida-se, assim, definitivamente a "falsa aparência", como se o objeto, que representa a magnitude do valor de outro objeto, possuísse sua forma equivalente independente dessa relação, como uma propriedade social que decorre da sua natureza. $O$ fato de ser o dinheiro uma mercadoria transformada em dinheiro, devido a representação das demais em seu valor, torna-se fantasmagórico, pois aparentemente é o inverso, como se as demais mercadorias representassem seu valor no dinheiro, porque ele é dinheiro.

Essa inversão reside no seguinte fato: como na sociedade capitalista as relações sociais se dão por ocasião das trocas das mercadorias, que por sua vez são objetos de uma produção, o caráter social do trabalho aparece na existência monetária da mercadoria e, por conseguinte, algo situado fora da produção real. O dinheiro está além da produção. Ou seja, as relações sociais são relações reificadas entre as pessoas e relações sociais entre coisas.

Este raciocínio revela o caráter do fetichismo, pois é a "personificação das coisas e reificação das relações de produção" (ROSDOLSKY, 2001).

\subsubsection{O Fenômeno da Reificação}

LUKÁCS (2003) verificou, partir das análises econômicas de MARX (1985), o surgimento de problemas fundamentais resultantes do fetichismo da mercadoria como objetividade, de um lado, e comportamento humano, de outro.

Esses problemas são específicos do capitalismo moderno. Todas as formas de trocas de sociedades primitivas, bem como formas de dinheiro em 
sociedades escravagistas não propiciavam condições para que a extensão de troca mercantil fosse o modo dominante do metabolismo de uma sociedade. Os pensamentos modernos, já reificados, imaginam esta questão como somente quantitativa, mas trata-se aqui de uma questão principalmente qualitativa (LUKÁCS, 2003) ${ }^{43}$.

A diferença qualitativa reside no fato desse metabolismo social exercido pelas mercadorias reagir sobre o tipo e a validação dessa própria forma ${ }^{44}$.

Somente no contexto em que a mercadoria surge como categoria universal de todo ser social, a reificação aparece com importância decisiva, tanto para o desenvolvimento objetivo desta sociedade, quanto para a atitude do homem a seu respeito, para a submissão de sua consciência às formas nas quais essa reificação se exprime ${ }^{45}$.

A relação social do homem assume a relação das coisas. O homem é confrontado com seu próprio trabalho como algo objetivo, independente dele e que o domina por leis próprias, que lhes são estranhas. Isto ocorre tanto sob aspecto objetivo quanto subjetivo.

Objetivamente, quando as leis desta nova ordem social, do mundo das mercadorias, se apresentam como algo acabado e, mesmo gradualmente assimiladas, demonstram-se como algo intransponível.

Subjetivamente, quando a atividade do homem (seu trabalho) se objetiva em relação a ele, torna-se uma mercadoria submetida à objetividade estranha aos homens, sujeita às leis sociais de movimentos independentes, tais quais qualquer mercadoria desse sistema ${ }^{46}$.

A universalidade da forma mercantil condiciona uma abstração do trabalho humano que se objetiva nas mercadorias ${ }^{47}$.

O desenvolvimento e o aumento da complexidade do processo de trabalho, desde a manufatura mais simples até a indústria, traz consigo uma

\footnotetext{
${ }^{43}$ Lukács, Georg. História e consciência de classe. São Paulo: Martins Fontes, 2003. p. 195. Observação: este livro foi originalmente lançado em 1923.

${ }^{44}$ Ibidem. p. 196.

45 Ibidem. p. 198.

${ }^{46}$ Ibidem. p. 199.

${ }^{47}$ Ibidem. p. 200.
} 
racionalidade e uma mecanização crescente. Esse processo fragmenta cada vez mais a atividade, interrompendo a relação do trabalhador com o produto final, reduzindo o trabalho a uma função especial repetida mecanicamente. Adicionalmente, esta fragmentação permite figurar 0 trabalho como quantidade objetivamente calculável, opondo-se ao trabalhador sob uma forma de uma objetividade pronta e estabelecida. Essa mecanização racional penetra até a alma do trabalhador. Suas qualidades psicológicas são separadas de sua personalidade e objetivadas em relação a ela para serem integradas a sistemas especiais e racionais e reconduzidas ao sistema calculador ${ }^{48}$.

O princípio da possibilidade do cálculo opera as seguintes modificações no sujeito e no objeto do processo econômico:

- Rompe a unidade orgânica do produto. Analisa cada conjunto complexo de seu elemento, pelo estudo das leis parciais de sua produção. A unidade do produto desaparece. A unidade de produto como mercadoria não coincide mais com sua unidade de valor de uso;

- Como conseqüência dessa fragmentação do objeto, fragmenta-se também o sujeito. $O$ trabalho do homem é simples fonte de erro na complexidade produtiva. $\mathrm{O}$ indivíduo não é mais portador desse processo, é incorporado como parte mecanizada num sistema mecânico pronto e independente dele, cujas leis deve se submeter ${ }^{49}$.

A atividade do trabalhador perde seu caráter ativo para um caráter contemplativo. Esse caráter transforma as categorias fundamentais da atitude imediata dos homens em relação ao mundo: reduz o espaço e o tempo a um mesmo denominador. $O$ trabalho do homem e seu valor

\footnotetext{
48 Ibidem. p. 201 - 202.

${ }^{49}$ lbidem. p. 202 - 204.
} 
reduzem-se ao tempo. Quando muito, o homem é a personificação do tempo. Desse modo, o tempo é abstrato, mensurável e transformado em espaço físico, em ambiente.

A objetivação da força de trabalho, que desde o início é realizada pela venda dessa força de trabalho, é, agora, adicionalmente, objetivada em relação ao conjunto de sua personalidade, devido à fragmentação e mecanização do seu trabalho. Essa objetivação é transformada em realidade intransponível, de modo que a personalidade torna-se expectadora impotente de sua existência nesse sistema estranho ${ }^{50}$.

Essa realidade industrial diferencia-se de outras realidades de produção de massa (como a construção das pirâmides egípcias), porque pressupõe a existência do trabalhador livre, disponível como mercadoria e que é livremente vendida. $O$ destino das massas exploradas pré-capitalistas não tinha relação com a sociedade, pois estes estavam à margem da considerada sociedade humana. Com a universalidade da categoria mercantil, essa relação muda radical e qualitativamente. $O$ destino do operário torna-se o destino geral de toda a sociedade. Desse modo, é absolutamente necessário a sociedade aprender a satisfazer todas as necessidades humanas sob a forma de trocas de mercadorias. Por isso o capitalismo moderno tende a, cada vez mais e profundamente, substituir por relações racionalmente reificadas as relações originais humanas. As quais não irão aparecer como relações disfarçadas entre coisas, mas como suas próprias relações pessoais, embora sejam, de fato, relações entre coisas ${ }^{51}$.

Para atingir este ponto, o princípio da mecanização e calculabilidade devem abarcar todos aspectos da vida. Os produtos que satisfazem as necessidades não aparecem mais como produtos do processo orgânico da vida de uma comunidade, mas como exemplares abstratos e isolados cuja posse depende de cálculos racionais. A pulverização de toda a vida em atos isolados de troca proporciona o trabalhador "livre", com seu destino atrelado ao destino dessa sociedade ou das trocas mercantis. A atomização do

${ }^{50}$ Ibidem. p. 204 - 205.

${ }^{51}$ Ibidem. p. 206 - 207. 
indivíduo é apenas o reflexo, na consciência, de que as "leis naturais" da produção capitalista abarcaram o conjunto das manifestações vitais da sociedade que, pela primeira vez, toda ela está submetida e o destino de todos os seus membros é movido por leis igualmente uniformes ${ }^{52}$.

A confrontação do indivíduo com a sociedade, a produção e a reprodução imediatas dessa vida, aparece ao indivíduo sob uma estrutura mercantil, imutável e apenas possível nos atos isolados da troca de mercadorias entre os produtores independentes. Para tanto, é necessário que o trabalhador apresente-se como proprietário de sua força de trabalho, sendo esta uma mercadoria. Essa auto-objetivação naturalizada revela o caráter da reificação, caráter este desumanizado e desumanizante ${ }^{53}$.

\subsubsection{A Objetivação do Fetichismo da Mercadoria}

RUBIN (1980), a partir do conceito do fetichismo analisou a objetivação, entendendo a característica distintiva da economia mercantil é a relação dos administradores e organizadores da produção independente das mercadorias. A produção é de mercadorias, ou seja, de produtos que não se destinam ao uso pessoal do produtor, mas para troca, para o mercado, para a sociedade.

A produção é administrada diretamente por estes produtores isolados das mercadorias e não pela sociedade. A sociedade não determina o que e quanto será produzido. Conseqüentemente, também não regula diretamente a atividade de trabalho de seus membros.

Esse sistema de produtores independentes contém, em si, uma divisão social de trabalho, que vincula diversos produtores em um sistema global de economia. Esse vínculo ocorre, então, através do mercado, no

\footnotetext{
52 Ibidem. p. 207 - 208.

53 Ibidem. p. 209.
} 
qual estes diversos produtores independentes trocam suas mercadorias produzidas.

Essa troca realizar-se-á pela comparação entre os valores das mercadorias. A sociedade regula os produtos do trabalho através do mercado, dos processos de trocas das mercadorias. Indiretamente, regula a atividade laboriosa das pessoas na medida em que a circulação de produtos é afetada por diversos aspectos.

A interação e a influência mútua da atividade de trabalho dos produtores individuais de mercadoria ocorre exclusivamente através das coisas.

Devido aos produtores trabalharem de forma independente e isolada, "a interconexão do trabalho social é manifestada na troca privada dos produtos individuais do trabalho" (RUBIN, 1980).

Assim, cada produtor de mercadorias é formalmente livre para produzir qualquer produto que queira. Porém quando ele leva o produto final ao mercado para trocá-lo, não é livre para determinar as proporções da troca, ficando condicionado as flutuações do mercado.

Essa dependência do mercado significa que a atividade do produtor depende da atividade produtiva de todos os membros da sociedade. $O$ produtor isolado de mercadorias, embora formalmente independente dos demais, está intimamente vinculado aos demais pelo processo de troca.

A troca se torna parte do verdadeiro processo de reprodução da atividade produtiva das pessoas.

$\mathrm{Na}$ sociedade mercantil, a independência de uma pessoa em relação a outras vem combiná-las com um sistema de dependência mútua em relação às coisas. As relações sociais de produção assumem, inevitavelmente uma forma reificada.

Um produto é um intermediário das relações sociais e a circulação dessas mercadorias está indissoluvelmente vinculada ao estabelecimento e realização das relações de produção entre as pessoas. O movimento dos preços de produtos no mercado é a única forma possível de manifestação das pessoas numa sociedade mercantil. 
Em uma sociedade mercantil, as coisas adquirem propriedades como valor, dinheiro, etc., graças às quais a coisa não só oculta as relações de produção entre as pessoas, como também as organiza, servindo com elo entre as pessoas. Oculta, ainda, as relações de produção porque elas só se realizam sob a forma de relação entre as coisas.

A circulação das coisas, na medida em que adquirem propriedades sociais específicas, de valor e dinheiro, não só expressa relação de produção entre homens, mas as cria.

A coisa adquire propriedades de valor, dinheiro, etc. não por suas propriedades naturais, mas em razão das relações sociais de produção, às quais está vinculada na economia mercantil. Assim, essas relações não são apenas simbolizadas por coisas, mas se realizam através das coisas.

$\mathrm{Na}$ economia mercantil os produtos do trabalho têm dupla essência: material (técnico-natural) e funcional (social). O trabalho, socialmente determinado, adquire características materiais e as coisas, características sociais.

\subsubsection{Mercado: Uma Forma Específica de Sociabilidade}

TEIXEIRA (1995) nos explica que, com a sociedade capitalista surge uma nova forma de sociabilidade. As dependências pessoais das antigas sociedades são substituídas por interdependências pessoais que se tecem por meio da nova divisão social do trabalho, conciliando os interesses particulares e egoístas dos produtores independentes através da troca de suas mercadorias.

Toda a relação de negócio estabelecida baseia-se na troca de algo que um quer por algo que o outro quer, o que passa a estar em jogo é a vantagem pessoal que cada indivíduo busca nesta relação.

A produção e a distribuição de toda a riqueza social passam a ser regidos por este processo de troca de coisas, por essa coisificação, que não 
obedece às necessidades de um todo social e, sim, como comentado, das vantagens pessoais que cada produtor independente tenta arrancar desta relação. Ocorre uma autonomização desta produção e distribuição das riquezas, regida por leis independentes da vontade pessoal ou de políticas para um todo social.

Segundo ENGELS (apud TEIXEIRA, 1995), este movimento altera todos os vínculos morais da sociedade, destruindo os valores humanos em benefício dos valores de troca; substituindo-se os princípios éticos pelos princípios de concorrência; as leis anteriores são substituídas pelas leis de oferta e procura. A humanidade se converte em mercadoria.

Valores são reificados. Como por exemplo, a liberdade e a igualdade, reconstruídas a partir do intercâmbio dos valores de troca. A liberdade e igualdade, agora reconstituídas, são expressões idealizadas destas novas relações de troca.

O mercado passa ser a base real no qual se fundam todas as relações jurídicas, políticas e social. A partir desta nova determinação social, os valores tomam novos significados:

- Igualdade: Todo indivíduo é igual, se considerado que todo indivíduo é um "comerciante" em potencial, que pode trocar sua mercadoria;

- Liberdade: Todo indivíduo é livre para buscar no mercado, a mercadoria que desejar para trocar com a sua;

- Reciprocidade: À medida que um indivíduo satisfaz a necessidade do outro quando Ihe entrega sua mercadoria, também se satisfaz pela mercadoria que recebe em troca deste outro. 
Os indivíduos possuem poder sobre as atividades dos outros, desde que possuam valores de troca, de dinheiro. Seu poder social, seu nexo social é portado em seu bolso.

As relações entre as pessoas são, portanto, mediadas pelas coisas, reificadas. Nessa relação mediatizada consiste o fetichismo da mercadoria. O fetichismo tem uma dupla determinação: enquanto fenômeno de existência social e enquanto fenômeno de consciência.

O dinheiro, por sua vez, revela com mais clareza esse fetichismo.

O dinheiro permite ao seu proprietário comprar qualquer mercadoria. É a expressão máxima para a realização da igualdade e da liberdade reificada. Todas as diferenças entre as pessoas somem. Um rei e um trabalhador podem ter o mesmo produto pelo mesmo preço.

Nessa nova forma de sociabilidade, as pessoas só existem enquanto personificação de relações econômicas. Relações econômicas que tem o dinheiro como valor equivalente geral, que medeia toda possibilidade de troca. O dinheiro assume, então, várias funções simultâneas:

- Meio de circulação, estabelecendo vínculo entre comprador e vendedor;

- Meio de pagamento, estabelecendo vínculo entre devedor e credor;

- Capital variável, estabelecendo vínculo entre capitalistas e trabalhadores;

Ao organizar as relações entre as pessoas, ele aparece como criador dessas relações, ocultando-as ao fazê-las parecer como relação entre as coisas. Daí ser o fetichismo da mercadoria um fenômeno da existência social. 
Como fenômeno de consciência, o fetichismo deriva da condição do dinheiro poder obter toda e qualquer riqueza. $\mathrm{O}$ dinheiro adquire, assim, um poder mágico. Como se houvesse uma transmigração dos poderes do homem para o dinheiro. O dinheiro aparece como sendo, ele próprio, a capacidade e as virtudes humanas, como criador das relações sociais.

A consciência da sociedade capitalista é produto de sua forma específica de sociabilidade, transformando até mesmo o homem, através de sua força de trabalho, em mercadoria. Ou seja, transforma o homem em objeto e as coisas em sujeitos das relações sociais. É uma relação reificada, desumanizada, na qual o homem não é realmente homem.

Mas o dinheiro apenas será capaz de transformar as relações humanas em relações reificadas somente onde tiver condições para isso. Assim, apenas quando a força de trabalho se torna mercadoria, o dinheiro passa a ser usado para assalariar o trabalhador.

A relação de força de trabalho como mercadoria se dá por dois lados contraditórios: o trabalhador que tem apenas sua força de trabalho como mercadoria disponível para ter acesso ao mundo do mercado e o capitalista que tem na força de trabalho a única mercadoria que pode multiplicar seu capital. Assim, o dinheiro assume sua função de capital variável. Ele transmigra para si a vontade do capitalista e do trabalhador, atendendo ambos desejos. Nessas condições é que opera a inversão fundamental e singular da sociedade capitalista, onde o homem torna-se objeto e as coisas, sujeito.

Essa inversão explica a consciência fetichizada das pessoas, impedidas de perceber a verdadeira essência da sociedade capitalista, tanto na sociedade exploradora, como e principalmente, no modo de vida estruturalmente amoral, a-ético e desumano.

A mercadoria passa a constituir uma força legitimadora das relações sociais, principalmente como força ideológica dessas relações. 


\subsubsection{A Reificação da Razão: A Racionalidade Técnica}

HORKEIMER (1976) parte do conceito de reificação, desta transformação regida por um novo metabolismo social, para pensar sobre qual racionalidade surge a partir desta mudança. $O$ autor trabalha conceitos de razão objetiva e razão subjetiva. A primeira, vista como fins e a segunda, como meios.

Para explicar o conceito de razão objetiva, buscou a sustentação em Sócrates, afirmando que a razão, concebida como compreensão universal, deve determinar crenças, regular relações entre os homens e entre o homem e a natureza. Por isso, afirma HORKEIMER (1976), que Sócrates "morreu porque submeteu as idéias mais sagradas e correntes de sua comunidade e seu país à crítica do daimonium, ou pensamento dialético, como Platão chamou" ${ }^{\prime 4}$.

Esta razão de fins ou objetiva, por um lado, denota como essência uma estrutura inerente à realidade que por si mesma exige um modo específico de comportamento em cada caso, seja uma atitude prática ou teórica. Por outro lado, o termo razão objetiva pode designar o próprio esforço e capacidade de refletir sobre tal ordem objetiva. "Os sistemas filosóficos da razão objetiva implicam a convicção de que se pode descobrir uma estrutura fundamental ou totalmente abrangente do ser e de que disso se pode derivar uma concepção de destino humano"

A questão é que, nos tempos modernos, "a razão tem revelado uma tendência para dissolver o seu próprio conteúdo objetivo". Os séculos XVI e XVII marcam o divórcio entre a religião e a razão, porém, do modo como ocorreu, serviu para enfraquecer o aspecto objetivo da razão.

No século XVII, "o aspecto objetivo da razão ainda predominava, pois o principal esforço da filosofia racionalista foi formular uma doutrina do

\footnotetext{
${ }^{54}$ Horkheimer, Max. Eclipse da razão. Rio de Janeiro: Labor, 1976. p 19 - 20. Observação Livro originalmente lançado em 1946.

${ }^{55}$ Ibidem. p. $20-21$.
} 
homem e da natureza que pudesse preencher a função intelectual - pelo menos para os setores privilegiados da sociedade - que a religião tinha preenchido anteriormente". Estes sistemas filosóficos ainda preservavam a ética cristã, com objetivos visados na atividade social e individual que derivavam da suposição de existência de certas idéias inatas ou intuições evidentes por si mesmas e se ligavam, assim, ao conceito de verdade objetiva, embora esta verdade - e aí reside a diferença - não fosse mais vista como garantida por qualquer dogma extrínseco às exigências do próprio pensamento. Ou seja, quando a filosofia tentou suplantar a religião, sua intenção não era abolir a verdade objetiva, mas apenas tentar dotá-la de novo fundamento. A suposição de uma realidade que pudesse ser compreendida era o terreno comum dos conflitos entre o catolicismo e a filosofia racionalista européia ${ }^{56}$.

Posteriormente, houve um aparente apaziguamento deste conflito original, pois a religião e a filosofia foram consideradas ramos separados da cultura. As "pessoas se reconciliaram gradativamente com a idéia de que cada um vive a sua própria vida dentro dos muros de seu comportamento cultural, tolerando o outro". Para HORKHEIMER (1976), esse apaziguamento do conflito original afetou profundamente a filosofia e a religião. O autor entende que os filósofos iluministas que atacaram a religião em nome da razão, mataram a metafísica e sua racionalidade objetiva, e não a Igreja. Sendo um ramo separado da cultura, toda busca pela verdade soava como especulativa, a metafísica especulativa transforma-se em sinônimo de mitologia e superstição. Poderíamos dizer que até a palavra razão ficou suspeita de conotar alguma entidade mitológica ${ }^{57}$.

HORKHEIMER (1976) enfatiza que:

Todas essas conseqüências estavam contidas em germe na idéia burguesa de tolerância, que é ambivalente. Por um lado, tolerância significa liberdade frente às normas da autoridade dogmática; por outro, conduz a uma atitude de neutralidade em relação a todo conteúdo espiritual, que se

${ }^{56}$ Ibidem. p. 22 - 25.

${ }^{57}$ Ibidem. p. 26 - 27. 
submete assim ao relativismo. Cada domínio cultural preserva a sua "soberania" em relação à verdade universal. O modelo de divisão social do trabalho se transfere automaticamente para a vida do espírito, e esta divisão do reino da cultura é um corolário da substituição da verdade objetiva pela razão formalizada, essencialmente relativista ${ }^{58}$.

A formalização da razão colocou-a a salvo de qualquer ataque sério da parte dos metafísicos ou da teoria filosófica, e esta segurança parece têla tornado um instrumento social extremamente prático. $\mathrm{Na}$ era industrial, a idéia de interesse pessoal conquistou gradativamente o primeiro plano e finalmente suprimiu os outros motivos considerados fundamentais ao funcionamento da sociedade. Posteriormente "o conteúdo da razão foi arbitrariamente reduzido a ser simplesmente uma parte deste conteúdo, em sua extensão, e apenas um de seus princípios, na sua composição; o particular tomou lugar do universal" ${ }^{\prime 29}$.

Tendo cedido na sua autonomia, a razão tornou-se um instrumento.

Esta razão, não mais autônoma, chamada por HORKHEIMER (1976) de razão subjetiva, é aquela caracterizada pela faculdade de classificar, inferir e deduzir, não importando qual é o conteúdo específico de sua ação; não atentando aos fins de sua ação. Ela se concebe necessariamente com a adequação de procedimentos a propósitos tidos mais ou menos como certos e que se presumem auto-explicativos ${ }^{60}$. Qualquer uso dos conceitos que transcenda a sumarização técnica e auxiliar dos dados factuais foi eliminado como último vestígio da superstição. É como se o próprio pensamento tivesse reduzido ao nível do processo industrial, submetido a um programa estrito, em suma, tivesse se tornado uma parte e uma parcela da produção. HORKHEIMER (1976) cita TONYBEE (1935) que diz sobre "a tendência do oleiro tornar-se escravo de seu barro (...) no mundo da ação, sabemos como é desastroso tratar animais ou seres humanos como se eles fossem paus e

\footnotetext{
58 Ibidem. p. 27 - 28.

59 lbidem. p. 28 - 29.

60 Ibidem. p. 13.
} 
pedras. Por que devíamos supor que esse tratamento fosse menos equivocado no mundo das idéias"? ${ }^{61}$

Quanto mais as idéias se tornam automáticas, instrumentalizadas, menos alguém vê nelas pensamentos com algum significado próprio. O significado é suplantado pela função ou efeito no mundo das coisas e dos eventos. Tal mecanização é na verdade essencial à expansão da indústria e conduz a uma espécie de materialidade e cegueira que se torna fetiche, uma entidade mágica que é aceita ao invés de ser intelectualmente apreendida ${ }^{62}$.

Quanto mais emasculado se torna o conceito de razão, mais facilmente se presta à manipulação ideológica e à propagação das mais clamorosas mentiras. A razão subjetiva se conforma a qualquer coisa. Pode se prestar ao uso tanto dos adversários quanto dos defensores dos tradicionais valores humanitários ${ }^{63}$.

HORKHEIMER (1976) utiliza o exemplo do princípio da maioria, inseparável do princípio da democracia, para demonstrar como essa desumanização do pensamento tem afetado os próprios fundamentos da nossa civilização: supõe-se que as resoluções de uma maioria são totalmente válidas para uma comunidade, porque os homens são os melhores juízes dos seus próprios interesses. Porém, qual a condição dos homens para "conhecerem seus próprios interesses"? Como ele adquiriu este conhecimento? Na proposição, "um homem conhece..." há uma referência implícita de uma agência que não é totalmente arbitrária. Destituídos do seu fundamento racional, o princípio da democracia torna-se exclusivamente dependente dos chamados interesses do povo e estes são funções de forças econômicas cegas. Quanto mais o julgamento do povo é manipulado por toda espécie de interesses, mais a maioria é apresentada como árbitro da vida cultural. Quanto mais a propaganda científica faz da

\footnotetext{
${ }^{61}$ Ibidem. p. 29 - 30.

62 Ibidem. p. 30 - 31 .

63 Ibidem. p. 32 - 33.
} 
opinião pública um simples instrumento de forças obscuras, mais a opinião pública surge como um substitutivo da razão ${ }^{64}$.

Segundo o ponto de vista da razão formalizada, uma atividade só é racional quando serve a outro propósito como, por exemplo, a saúde ou o descanso, que ajuda na recuperação da energia produtiva. Em outras palavras, a atividade é simplesmente um instrumento, pois tem seu significado determinado a partir de sua ligação com outros fins. A própria idéia de hobby, ou "diversão", não expressa qualquer pesar pelo desaparecimento da razão objetiva. Como gostos racionalizados e aceitos, os hobbies são considerados necessários para manter a pessoa de bom humor, tornando-se uma instituição. O bom humor estereotipado, que nada mais é do que um requisito psicológico de eficiência profissional, pode se esvair juntamente com outras emoções, assim que se perde o último vestígio de que estas se ligavam outrora a idéia de divindade. "Aqueles que 'sorriem sempre' começam a parecer tristes e talvez até mesmo desesperados"65.

Assim, na racionalidade técnica, a probabilidade, ou melhor, o cálculo substitui a verdade, e o processo histórico que, na sociedade tende a tornar a verdade numa expressão vazia, recebe as bênçãos do pragmatismo, que transforma isso numa expressão vazia dentro da filosofia ${ }^{66}$.

Segundo o pragmatismo, a verdade não é para ser almejada por si mesma, mas na medida que funciona mais e nos conduz a algo que está afastado ou pelo menos é diferente da própria verdade. Para o pragmatista, a idéia é "pensar sobre tudo exatamente como tudo é pensado no laboratório, isto é, como uma questão de experimentação" (PEIRCE apud HORKHEIMER, 1976) ${ }^{67}$. HORKHEIMER (1976) ainda acrescenta:

Ao tentar transformar a física experimental num protótipo de todas as ciências e modelar todas as esferas da vida intelectual segundo as técnicas de laboratório, o pragmatismo é o correlato do industrialismo moderno, para quem a fábrica é o protótipo da existência humana e que modela todos os

\footnotetext{
64 Ibidem. p. 34 - 38.

65 Ibidem. p. 44 - 46.

${ }^{6}$ Ibidem. p. 51.

67 Ibidem. p. 52 - 54.
} 
ramos da cultura segundo a produção na linha de montagem ou segundo o escritório executivo racionalizado ${ }^{68}$.

As coisas da natureza tornam-se idênticas aos fenômenos apresentados quando submetidas às práticas dos laboratórios, cujos problemas expressam, por sua vez, os problemas e interesses da sociedade como ela é. O pensamento passa a ser aferido por algo que não é pensamento, por seu efeito na produção ou seu impacto na conduta social, como a arte passa a ser avaliada como algo que não é arte, seja a bilheteria, seja o valor da propaganda ${ }^{69}$.

A satisfação, trazida pela evolução tecnológica na ciência e pela serenidade e equilíbrio moral na religião, segundo os pragmatistas, faz com que eles transformem esta satisfação do sujeito em critério de verdade, diante da idéia de que a verdade possa causar o oposto da satisfação e tornar-se completamente chocante para a humanidade ${ }^{70}$.

Se a satisfação, então partindo dos desejos das pessoas, tais como são realmente, ou seja, condicionados por todo o sistema social vivido por elas - um sistema que torna mais do que duvidosa a afirmação de que os desejos dessas pessoas sejam de fato os seus - for aceita de maneira acrítica, sem transcender o seu alcance imediato e subjetivo, então as pesquisas de mercado ou os inquéritos Gallup seriam meios mais adequados para sua indagação do que a filosofia ${ }^{71}$.

A razão que se despoja de qualquer relação com seu conteúdo objetivo e de seu poder de julgar este último, e a reduz a um papel de uma agência executiva mais preocupada com o como do que com o porquê, transforma-se cada vez mais num simples mecanismo de registrar fatos. $A$ razão subjetiva perde toda espontaneidade, produtividade e poder para descobrir e afirmar novas espécies de conteúdo, perde a própria subjetividade, neutraliza-se. Como uma lâmina de barbear freqüentemente

\footnotetext{
68 Ibidem. p. 57.

69 lbidem. p. 56 - 58.

70 lbidem. p. 58 - 59.

71 Ibidem. p. 60 - 61 .
} 
afiada, esse "instrumento" se torna demasiado tênue e no fim inadequado até mesmo para dominar as tarefas formalísticas ao qual é limitado ${ }^{72}$.

MARCUSE (1967) irá trabalhar a idéia de racionalidade técnica, desenvolvida por HORKHEIMER (1976), aplicado-a a outras esferas, notadamente na esfera do mercado, dentro da civilização industrial desenvolvida.

Para MARCUSE (1967), o aparato tecnológico deveria servir para tornar possível a autonomia individual, porém, na visão do autor, opera-se a tendência oposta: o aparato impõe suas exigências econômicas e políticas para a defesa e a expansão ao tempo de trabalho e ao tempo livre, às culturas material e intelectual. Na forma como se organizou a base tecnológica, a sociedade industrial contemporânea tornou-se "totalitária", por meio de uma coordenação técnico-econômica não terrorista, que opera através da manipulação das necessidades por interesses adquiridos. Impede, assim, o surgimento de uma oposição eficaz ao todo. Constitui-se um totalitarismo, não a partir de um governo ou partido, mas através de um sistema específico de produção e distribuição, que bem pode ser compatível com o "pluralismo" de partidos, jornais e "poderes contrabalançados"73.

As necessidades, acima do nível biológico, sempre foram précondicionadas. Para que algo seja tomado como necessidade depende de poder ou não ser ele visto como desejável e necessário aos interesses e instituições comuns. MARCUSE (1967) separa, assim, as necessidades em "verídicas" e "falsas":

Falsas são aquelas superimpostas ao indivíduo por interesses sociais particulares ao reprimi-lo: as necessidades que perpetuam a labuta, a agressividade, a miséria e a injustiça (...) A maioria das necessidades comuns de descansar, distrair-se, comportar-se e consumir de acordo com os anúncios, amar e odiar o que os outros amam e odeiam, pertence a essas categorias de falsas necessidades (...) Tais necessidades têm um conteúdo e funções sociais determinados por forças externas sobre os quais o individuo não tem controle algum; o desenvolvimento e a satisfação

\footnotetext{
72 Ibidem. p. 62.

73 Marcuse, H. A ideologia da sociedade industrial. Rio de Janeiro: Zahar, 1967. p. 24 25. Este livro foi originalmente lançado em 1964 com o título Unidimensional Man
} 
dessas necessidades são heterônomos (...) independente do quanto ele se identifique com elas e se encontre em sua satisfação, elas continuam a ser o que eram de início - produtos de uma sociedade cujo interesse dominante exige repressão (...) Então o resultado é a euforia na infelicidade ${ }^{74}$.

A racionalidade técnica é a base para esta superimposição de necessidades, pois "quanto mais racional, produtiva, técnica e total se torna a administração repressiva da sociedade, tanto mais inimagináveis se tornam os modos e os meios pelos quais os indivíduos administrados poderão romper a sua servidão e conquistar sua própria libertação", e "toda libertação depende da consciência de servidão e o surgimento dessa consciência é sempre impedido pela predominância de necessidades e satisfações que se tornaram, em grande proporção, o próprio indivíduo"75.

$O$ jugo de um todo repressivo pode transformar a liberdade em poderoso instrumento de dominação. $O$ alcance da escolha não é fator decisivo do grau de liberdade; mas o que pode ser escolhido e o que é escolhido pelo indivíduo. "A livre escolha entre ampla variedade de mercadorias e serviços não significa liberdade se esses serviços e mercadorias sustêm os controles sociais sobre uma vida de labuta e temor isto é, se sustêm alienação". A eleição livre de senhores não abole os senhores ou os escravos ${ }^{76}$.

Este precondicionamento não é realizado pelo controle e a divulgação de massa. Este artifício tem seu papel a posteriori. As pessoas entram nessa fase já como receptáculos pré-condicionados. Segundo MARCUSE (1967), a diferença decisiva está no:

aplanamento do contraste (ou conflito) entre as necessidades dadas e possíveis (...) aí a chamada igualação das distinções de classe revela sua função ideológica (...) se o trabalhador e patrão assistem ao mesmo programa de televisão e visitam os mesmos lugares pitorescos, se a datilógrafa se pinta como a filha do patrão (...) essa assimilação não indica o desaparecimento de classes, mas a extensão com que as necessidades e satisfações que servem a

\footnotetext{
${ }^{74}$ Ibidem. p. 26.

75 lbidem. p. 28.

${ }^{76}$ Ibidem. p. 28.
} 
preservação do estabelecimento é compartilhada pela população subjacente ${ }^{77}$.

O autor entende que a extensão desses controles sociais são tais que o termo "introjeção" não cabe aqui para descrever a perpetuação destes controles, pois introjeção sugere uma variedade de processos relativamente espontâneos pelos quais um Eu (ego) transfere o "exterior" para o "interior". Dessa forma, introjeção subtende a existência de uma dimensão interior, distinta das exigências externas - uma consciência e um inconsciente individual separados da opinião e comportamento públicos. Nesse sentido, ainda há um espaço privado, no qual o homem pode ser "ele próprio". Este espaço, porém, se apresenta invadido e desbastado pela realidade tecnológica. A produção reivindica o indivíduo inteiro, a psicologia industrial deixou de limitar-se à fábrica. "O resultado não é o ajustamento, mas a mimese: uma identificação imediata do indivíduo com a sua sociedade e, através dela, com a sociedade em seu todo". Esta identificação não é uma ilusão, é uma realidade, que constitui uma etapa mais progressiva de alienação inteiramente objetiva. O sujeito alienado é "engolfado por sua existência alienada". Há apenas uma dimensão. As conquistas do progresso desafiam tanto a condenação como a justificação ideológicas. Perante o tribunal dessas conquistas, a "falsa consciência" de sua racionalidade se torna a verdadeira consciência ${ }^{78}$.

Esta absorção da ideologia pela realidade não significa fim da ideologia, mas ao contrário, a civilização industrial é mais ideológica do que suas antecessoras, visto que, segundo ADORNO (apud MARCUSE, 1967), "a ideologia está no próprio processo de produção".

A citação anterior revela aspectos políticos e totalizantes da racionalidade tecnológica. Os produtos doutrinam e manipulam; promovem uma falsa consciência imune a sua falsidade. A doutrinação que eles portam deixa de ser puramente publicidade, torna-se estilo de vida. E,

\footnotetext{
${ }_{77}$ Ibidem. p. 29.

${ }^{78}$ Ibidem. p. 30 - 31.
} 
aparentemente, um bom estilo de vida, por isso militando contra a transformação qualitativa. Surge assim, o que MARCUSE (1967) descreve como um padrão de pensamento e comportamento unidimensionais, "no qual as idéias, as aspirações e os objetivos que, por seu conteúdo transcendem o universo estabelecido da palavra e da ação, são repelidos e reduzidos a termos desse universo. São redefinidos pela racionalidade do sistema dado e de sua extensão quantitativa"79.

Essa tendência ao padrão unidimensional pode ser verificada, segundo MARCUSE (1967), ainda pela relação na evolução do método científico e nas ocupações espirituais, metafísicas e boêmias:

- No método científico, através do operacionalismo nas ciências físicas e do behavorismo nas ciências sociais, os significados dos conceitos são restringidos à representação de operações e comportamento especiais. BRIDGMAN (apud MARCUSE, 1967) conclui que "o conceito é sinônimo do conjunto de operações correspondentes". Essa nova racionalidade, em sua negação dos elementos transcedentes da razão, forma a réplica acadêmica do comportamento socialmente exigido ${ }^{80}$;

- Nas outras ocupações, as promoções de gêneros Zen, existencialismo e estilos exóticos de vida, mostram-se como formas de protestos e transcendências, porém não são mais contraditórias ao status quo e não são mais negativas. São parte cerimonial do behavorismo prático, sua negação inofensiva, rapidamente digerida pelo status quo como parte da sua dieta salutar $^{81}$.

\footnotetext{
79 Ibidem. p. 32.

80 lbidem. p. 32 - 33.

${ }^{81}$ Ibidem. p. 33 - 34.
} 
Esses conceitos operacionais e behavoristas voltam-se contra os esforços para libertar o pensamento e o comportamento da realidade dada e para as alternativas suprimidas. O campo comum que une esses conceitos é de uma sociedade avançada que transforma o progresso científico em instrumento de dominação ${ }^{82}$.

Por fim, MARCUSE (1967) conclui que:

Quando este ponto é atingido, a dominação - disfarçada em afluência e liberdade - se estende a todas as esferas da vida pública e privada, integra toda oposição autêntica, absorve todas as alternativas. A racionalidade tecnológica revela o seu caráter político ao se tornar o grande veículo de melhor dominação, criando um universo verdadeiramente totalitário no qual a sociedade e natureza, corpo e mente, são mantidos num estado de permanente mobilização para defesa deste universo ${ }^{83}$.

${ }^{82}$ Ibidem. p. 35.

${ }^{83}$ Ibidem. p. 37. 


\title{
4. O MEDICAMENTO NO UNIVERSO DA RACIONALIDADE
}

\section{TÉCNICA}

\author{
"Eu folheava os catálogos e me perguntava: \\ 'que tipo de porcelana me define como pessoa?' \\ Eu tinha de tudo, até mesmo pratos de vidro com pequenas imperfeições, \\ prova de que foram forjados por trabalhadores indígenas, \\ simples e honestos, sei lá de onde. \\ Costumávamos ler pornografia. Agora era catálogo de loja." \\ (Narração do protagonista do filme Clube da Luta. EUA. 1999)
}

A expansão da mercantilização, de uma forma geral, incluindo-se aí também a da doença, é feita indiretamente através de instâncias e mediações, ou seja, a partir da construção histórica de subordinação de lógicas pela a lógica mercantil.

HORKHEIMER (1976) trabalha com essa idéia, pois a lógica técnica explica o fenômeno da planificação das lógicas, fazendo com que tudo seja regido sob a mesma batuta, sob um mesmo diapasão.

A indústria age materialmente para que isto aconteça também com a ciência, regida sob uma lógica instrumental, já reificada. Com a ciência este fenômeno é mais contraditório ainda, pois ela, em tese, é a atividade dos homens para pensar nos seus fins.

Com a evolução do capitalismo, MARCUSE (1967) busca explicar que a produção nesse sistema já está superada e a criação das necessidades representa a próxima etapa de sua evolução, pois o valor de uso passa pelo crivo do mercado. Os riscos da não aceitação de um produto são, dessa forma, minimizados para que este momento de incerteza (ou liberdade) na esfera do consumo seja eliminado. Ou seja, uma possível crise do capital, que se daria na defasagem entre a produção e o consumo, é resolvida com o planejamento da esfera do consumo através da criação de necessidades.

E como é possível esta criação de necessidades? 
A racionalidade moderna, como visto em MARX (1985) e outros autores citados no capítulo anterior, está edificada sobre o conceito da abstração que se origina no processo produtivo.

A comparação de trabalhos sociais, através do valor de troca, sem o saber, naturalizando as relações materiais estabelece como se dá à reflexão (ou racionalização) sobre as formas de vida humana: após esta própria forma de vida, possibilitando tornar natural o que não é. Este é o pensamento fetichizado.

A racionalidade se torna poderosa, conforme estabelecido por COHEN (1978), pois enquanto o fetiche religioso resulta de um processo mental, o fetiche econômico deriva do processo de produção e tem uma característica fundamental: persiste mesmo quando desvendado. A forma social da relação oculta o conteúdo material.

O dinheiro é simbólico nesta racionalidade de base abstrata, conforme visto em ROSDOLSKY (2001). O valor de troca do dinheiro (uma abstração) é ele mesmo, mas com uma existência autônoma fora dele. O caráter social do trabalho produtivo está na existência monetária da mercadoria, o dinheiro, que está fora da produção. Ou seja, o que está fora da produção revela o caráter social do que está dentro. É a abstração da abstração.

É nessa base abstrata que a reificação aparece com importância decisiva, tanto para o desenvolvimento objetivo desta sociedade, quanto para a atitude do homem a seu respeito, para a submissão de sua consciência às formas, nas quais essa reificação se exprime.

Objetivamente as leis desta nova ordem social, do mundo das mercadorias, se apresentam como algo acabado e, mesmo que gradualmente assimiladas, demonstram-se como algo intransponível. A troca mercantil é a forma dominante do metabolismo desta sociedade e a mercadoria torna-se categoria universal de todo ser social.

A mecanização crescente do processo de manufatura traz consigo uma racionalização crescente. $\mathrm{Na}$ base abstrata do pensamento, fruto do processo produtivo material, a racionalização apresenta-se sob forma de objetividade pronta e estabelecida. Essa mecanização racional penetra até 
na alma do homem. O homem é parte mecanizada num sistema mecânico pronto e independente dele, a cujas leis deve se submeter. Essa objetivação é transformada em realidade intransponível, sua personalidade torna-se expectador impotente de sua existência inserida em um sistema estranho.

Nessa base material, o homem acaba por se auto-conceber, de forma naturalizada, como parte de um processo produtivo, ele se fragmenta, perdendo, assim, a experiência totalizante com relação à vida. Esta experiência fragmentada leva ao pensamento fragmentado. A forma de pensar, ou a racionalidade, reproduz o materialmente determinado, ou seja, reproduz o processo produtivo racionalizado, técnico. E, por ser reificada, a própria racionalidade fragmentada é concebida, em sua origem, como natural.

Essa fragmentação do pensamento é a base que estabelece a separação entre dor e homem, entre a separação do corpo da alma promovida por Descartes. Esta desintegração do homem com o cosmo, do homem consigo mesmo e com suas dores, leva à heteronomia, à dependência do terceiro, da medicina e do médico, no caso da doença. $O$ outro passa a reger o seu destino.

E quem é este outro?

Este outro é toda a mediação dirigida por forças econômicas cegas responsáveis pela criação das necessidades que buscam minimizar a defasagem entre a produção e o consumo.

Uma das mais poderosas mediações propiciadoras da expansão da mercantilização da doença é a medicalização. A medicalização, enquanto possibilidade da medicina invadir todas as áreas da vida, tornando-as objeto de cuidados médicos específicos, independentemente de haver ou não sintomas mórbidos (ILLICH, 1975) $)^{84}$ e atuando pela redefinição de experiências e comportamentos humanos como se fossem problemas médicos (TESSER, 2006) ${ }^{85}$.

\footnotetext{
${ }^{84}$ Aspecto abordado na seção 3.1

${ }^{85}$ Idem
} 
Embora, no capítulo três, MOYNIHAN e col. (2002) tenha afirmado que "algumas formas de medicalizar a vida ordinária agora podem ser melhores descritas como mercantilização da doença", o ponto de vista desenvolvido aqui é um pouco diferente. A medicalização viabiliza o estabelecimento da mercantilização da doença. Medicalizar a vida é fertilizar o terreno onde florescerá a venda de tratamentos.

E como a mercantilização da doença utiliza a medicalização como meio para se estabelecer?

Pela colonização da lógica mercantil nas diversas lógicas relacionadas às áreas da vida humana invadidas pela medicalização.

Como o mecanismo da medicalização é trazer para a medicina todas as questões relativas a experiências e comportamentos humanos, uma das principais áreas de colonização da lógica mercantil é a área médica.

A começar pelo papel hegemônico do medicamento, historicamente assumido como primeira opção na escolha dos tratamentos (seção 1.2.2). Os dados vistos em toda seção 1.2.2 mostram a importância da propaganda médica para a indústria, tanto em termos quantitativos, representado pelo alto volume de investimentos em propaganda, quanto em termos qualitativos, representado pelo tipo de propaganda médica, com informações falsas e/ou desorientadoras que revelam a clara opção de vender em detrimento a informação correta. E esta propaganda, como discutido na seção 1.2.2.4, possui grande influência nas prescrições médicas.

No caso da depressão, seção 2.4.3, é visto que a promoção não se dá apenas pela propaganda médica dos medicamentos. Os comprometimentos em troca de informações, os congressos fortemente patrocinados e até os jornais médicos são alvos desta colonização.

Contudo, a colonização da área médica vai além dos limites da hegemonia do medicamento e de sua propaganda. A ação da indústria na formação dos consensos médicos (seção 2.4.2, o caso do colesterol) é uma das novas formas encontradas de desvirtuamento da lógica médico-científica pela lógica mercantil. Este tipo de colonização é ainda mais eficiente e, por isso, mais perigoso. A opinião contida numa propaganda é claramente a 
opinião de quem a veicula, pois a procedência da informação está manifestada. No caso dos consensos médicos, não. O que aparece como forma de opinião de um grupo de médicos, sumidades no assunto (e devido a isto, formadores de opinião ${ }^{86}$ ) é, na verdade, uma mensagem desenvolvida pela indústria interessada em vender um conceito que carrega grande oportunidade de negócios.

A indústria busca diversos recursos para expandir sua lógica na área médica. Um deles é a utilização off-label. Embora seja um expediente próprio da área médica, a indústria se utiliza dele fomentando os usos muito para além do considerado racional nos termos do URM. Um exemplo simbólico é uso do Viagra, largamente utilizado para a disfunção sexual feminina, como visto na seção 2.5.6, sem ao menos haver consenso sobre a definição dessa doença.

A subordinação das lógicas é um mecanismo complexo. Para colonizar a área médica com maior eficiência, colonizam-se outras áreas. $A$ área científica, por exemplo, tem sido chave neste processo.

A seção 2.4.1 demonstra que a ação da indústria farmacêutica nos $\mathrm{NIH}$ lhe traz dupla vantagem: busca recursos públicos para financiar suas pesquisas ao mesmo tempo que traz os cientistas para dentro de seu círculo de influência. Como explicado por ANGELL (2004), os cientistas passam a fazer acordos lucrativos com empresas, aumentando a tendência favorável à indústria na pesquisa médica. Além disso, o ganho de royalties que as universidades passaram a ter, reduziu às críticas que estas faziam aos preços praticados pelas indústrias. Trabalhos científicos são enviesados, favorecendo a inclusão de pessoas no grupo alvo, ou passíveis de serem medicadas, como no caso da disfunção erétil, descrita na seção 2.5.4.

\footnotetext{
${ }^{86}$ A indústria estadunidense utiliza o termo key opinion leader ou líder de opinião chave para se referir a pessoas que possuem capacidade de formar opiniões de grandes grupos. Normalmente estas pessoas são líderes de algum segmento, médicos (ou ainda outros profissionais de saúde) especialistas em suas áreas, ou líderes dentro de associações de pacientes. Suas opiniões influenciam a opinião dos demais de seu segmento. Conseguir que esses líderes de opinião reproduzam alguma idéia interessante à indústria (a qual, por sua vez, será automaticamente reproduzida por àqueles influenciados por esta opinião) é uma das chaves para que a promoção de um produto ou de uma idéia tenha sucesso. Por isso são designados key opinion leader.
} 
Outras áreas vão sendo, uma a uma, colonizadas pela lógica mercantil.

A área política, com a indústria farmacêutica assumindo o posto da indústria que mais investe em lobby, nos EUA, fazendo com que sejam estabelecidas políticas favoráveis aos interesses industriais, como as políticas de financiamentos públicos para suas pesquisas e a extensão da vigência de patentes (seção 2.4).

A área da educação, através da utilização de professores como "agenciadores" da doença TDHA (hiperatividade), como visto na seção 2.5.5.

A área dos grupos de pacientes, no caso dos CHADD (seção 2.5.5).

A área da mídia, na qual a divulgação massiva de doenças passou a ser uma forma eficiente de propagação de conceitos. A seção 2.5.7 descreve como o transtorno bipolar é levado à esfera pueril, com publicação de livros e revistas sobre o assunto, digno até de ser capa da revista Time, de altíssima circulação. A seção 2.5.8 narra a divulgação da síndrome das pernas inquietas, com artigos que incentivam pacientes a perguntarem ao seu médico sobre a síndrome e a seção 2.5.6 descreve as várias formas de divulgação sobre a disfunção sexual feminina, incluindo sua apresentação no talk show da Oprah.

Mas a colonização mais importante talvez seja a colonização na área pessoal, de cada um de nós. O estabelecimento de concepções relacionadas ao sucesso na vida com a utilização de algum produto, provavelmente, é a forma mais eficaz da mercantilização da doença. O caso da halitose (seção 2.5.1), em que as pessoas não conseguirão se casar, ter filhos ou arrumar empregos se não resolverem o problema de hálito (utilizando, é claro, o Listerine) revela esta vertente. A medicalização da vida permite que a mercantilização da doença leve seus produtos a realizar todos os sonhos do utópico mundo burguês. No mundo cada vez mais dividido entre winners e losers, as condições humanas como problemas de ereção, calvície, obesidade e timidez não só passam a serem tratadas absolutamente como doenças, mas também começam a serem vistas sob o prisma da performance: o aumento da performance sexual, a adequação dos 
cabelos e do corpo a padrões estéticos. Os medicamentos deixam de ser somente produtos para o tratamento de doenças e passam a representar possibilidades e estilos de vida. Realiza-se o sonho da indústria de vender seu produto para qualquer pessoa.

Apesar de ILLICH (1975) e outros autores, desde a década de 70, demonstrarem que a medicalização é $o$ ato que menos contribui com a saúde pública, ela tem demonstrado possuir uma imagem hegemônica de solução para problemas de quase todas esferas da vida, inclusive àquelas não médicas. Esta contradição demonstra como a criação das necessidades, como etapa da evolução capitalismo, vista em MARCUSE (1967), tem vigor.

Quando ILLICH (1975) diz que o "desenvolvimento da faculdade de objetivação da dor é um dos resultados da formação científica do médico", ele se refere à transformação da dor em objeto, um passo decisivo para reduzir seu tratamento a uma forma também objetiva, ou seja, transformar o tratamento em objeto.

É possível fazer um paralelo entre a idéia de heteronomia, em ILLICH (1975) no qual "um outro rege o destino do homem", e em MARCUSE (1967), quando relata o desenvolvimento de necessidades heterônomas, desenvolvidas pelo sistema para se retro-alimentar, concebidas, pelo autor, como "falsas necessidades". Por serem necessidades heterônomas ao homem, precisam ser satisfeitas também por algo heterônomo ao homem, ou seja, um produto. A racionalidade técnica é condição para a superimposição de necessidades para a "administração total do indivíduo". Essas falsas necessidades podem ser muito bem aplicadas em qualquer situação prevista na mercantilização da doença. Tanto nas situações em que doenças moderadas são tratadas como graves (síndrome das pernas inquietas), quanto nos casos cujo fatores de risco são tratados como doenças (colesterol), e nos casos em que não há doença de fato, mas o contexto está ligado a um aumento de performance das condições normais da saúde do indivíduo (halitose e disfunção erétil). 
Esta última situação de "aumento de performance das condições normais do indivíduo" tem estreita relação com o que MARCUSE (1967) chama de "doutrinação provida pela manipulação do processo produtivo, através dos produtos". Esta doutrinação é responsável pela promoção de uma falsa consciência, imune a sua falsidade. Por isso, torna-se estilo de vida. Por sua vez este estilo de vida só é conseguido por meio de produtos, pois os mesmos estão na base desta doutrina.

Essa necessidade superimposta, agora como estilo de vida, tem uma musculatura extra na mercantilização da doença, é um estilo de vida sobre a vida, literalmente. Não é um estilo de vida como "ter um canal pago" ou um "carro novo". É um estilo de vida sobre dominar sua própria natureza. Sobre suas limitações físicas. Sobre a vida e sobre a morte. E isto é um fundamento para se obter todos os outros estilos de vida. Para o emprego, para o romance, para o casamento. Foi assim que concebeu a promoção do Listerine. A halitose como estilo de vida. A idéia de que "Listerine não fez um enxaquatório bucal tanto quanto fez a halitose", visto na seção 2.5.1, subverte o conceito; o produto passa a ser a halitose e não o Listerine. Típico da reificação, a coisa (Listerine) passa a ser a relação (halitose) e a relação (halitose) passa a ser a coisa (Listerine).

Para exemplificar como se têm trabalhado o conceito de estilo de vida, vejamos uma campanha publicitária para popularizar a andropausa ${ }^{87}$, deflagrada em novembro de 2006, pela empresa Shering, grupo Bayer Shering Pharma. Esta campanha contou com quatro peças espalhadas pela estação Clínicas do metrôn e tinham em comum os seguintes dizeres: "a andropausa pode afetar homens com mais de 40 anos e está relacionada à diminuição de Testosterona. Isto pode interferir na sua qualidade de vida. Converse com seu médico. www.eutesto.com.br" e o que as diferenciavam eram imagens com mensagens diretamente relacionadas ao estilo de vida. $\mathrm{A}$

\footnotetext{
${ }^{87}$ Andropausa é o termo popular para definir a diminuição da função sexual masculina. Normalmente ocorre por hipogonadismo, secreção inadequada de testosterona pelos testículos, associada aos sintomas correspondentes. Diferentemente da menopausa, que atinge todas as mulheres, a andropausa atinge um número reduzido de homens.

${ }^{88}$ A estação Clínicas do metrô localiza-se no município de São Paulo, próxima ao Hospital das Clínicas da Faculdade de Medicina da Universidade de São Paulo.
} 
imagem 1 apresentava um ventilador e a frase "Andropausa. Você sente muitas ondas de calor?". A imagem 2 apresentava uma tartaruga e a frase "Andropausa. Você anda devagar quase parando?". As imagens 3 e 4 apresentavam, respectivamente, um homem de terno, andado em uma praia e um homem arrastando um caiaque para dentro do mar, ambos com a frase "Andropausa. Conhecer mais é seguir em frente." A relação entre as fotos e as mensagens cria um sentido de "eterna juventude", de virilidade, de aumento de performance. Essas imagens podem ser vistas no Anexo desta dissertação.

O caso do Viagra também simboliza a venda do estilo de vida. Dado que o crescimento, entre 1998 e 2002, foi maior nos homens com idade entre 18 e 45 anos (seção 2.5.4), público que não é o alvo de uso do produto, de acordo com as indicações e a propaganda do produto (homens acima de 45 anos). As limitações do desempenho natural já não são mais vistas como algo aceitável. Num contexto já reificado, a melhoria de desempenho sempre será a opção de escolha, pois é nessa opção que reside o uso de um produto. E é nesse sentido que MARCUSE (1967) desenvolve a idéia de "unidimensonalidade". Nesta concepção, todas a possíveis opções estão limitadas dentro da opção de escolha "do que consumir" e não "de se consumir". Isto se deve porque a racionalidade técnica já deu conta de reificar o pensamento. Houve uma mimese da racionalidade, do pensamento, de forma que a opção será sempre reduzida àquela que circunscreve o consumo. Esta idéia de mimese pode explicar porque os esforços "racionalizantes" do URM têm pouco efeito se comparado à expansão da mercantilização da doença. A falsa consciência já se mimetizou como verdadeira. A racionalidade produtiva que leva 0 indivíduo a consumir já o tomou por inteiro.

O poder da necessidade superimposta é demonstrado pela categoria de medicamentos campeã de vendas: os medicamentos para baixar o colesterol. Vendas não para uma doença, mas para um fator de risco. Um paradoxo, a doença mais tratada não é uma doença. E esse fator de risco tem como tratamento mais largamente utilizado o medicamentoso. Esta 
redução do tratamento ao medicamento, minimizando todas as outras alternativas terapêuticas, revela o poder da necessidade superimposta.

Em 1987, quando a Pfizer lançou o Mevacor, e criou-se a possibilidade de se medicar pessoas saudáveis, realizou-se o que, em março de 1976, o então presidente da Merck, Henry Gadsden havia profetizado na revista Fortune: ele disse que, embora a Merck tivesse seu mercado limitado a pessoas doentes, ele gostaria que ela fosse mais parecida com a empresa de chicletes Wrigley's, ou seja, que a mesma pudesse vender para pessoas saudáveis, ou "vender para todas as pessoas" (MOYNIHAN, 2005).

LEFÈVRE (1991) identifica no medicamento três dimensões coexistentes; o medicamento como agente quimioterápico, como mercadoria e como agente simbólico.

Não podemos negar a necessidade eminente do medicamento em sua dimensão como agente quimioterápico, pois independente das questões filosóficas da relação saúde-doença, sempre chegará um momento que o homem se verá como uma natureza física, imerso no mundo físico a buscar um modo de vida, ou de cura (SAYD, 1995).

Por este motivo, resgatou-se no primeiro capítulo o debate sobre 0 uso racional dos medicamentos (URM) que, de certa forma, busca restabelecer o uso do medicamento na sua dimensão de agente quimioterápico. A racionalidade de uso colocado em pauta nesta discussão é justamente utilizá-lo quando e se necessário, numa tentativa, ainda que inconsciente, de fugir da unidimensionalidade diagnosticada por MARCUSE (1967). A Conferência de Nairobi vai nesta direção quando define que "o paciente deverá receber a medicação apropriada para sua situação clínica, nas doses e períodos adequados".

O medicamento, restrito a sua dimensão de agente quimioterápico, não geraria o debate sobre o URM tal como se apresenta. Ainda que se considere a dicotomia existente nos limites desta dimensão, ou seja, na natureza ambígua do agente quimioterápico que é, de acordo com Paracelso, ao mesmo tempo remédio e ao mesmo tempo veneno, ainda 
assim, este conflito poderia ser equacionado numa sociedade esclarecida, racional e com autonomia individual (nos sentidos de HORKHEIMER, 1976 e MARCUSE, 1967). A sobreposição da dimensão mercadoria à dimensão agente quimioterápico inverte inteiramente o papel do medicamento em sua totalidade. Não é à toa que emergem novas ramificações de estudo, como a farmacoepidemiologia, revelando a grande contradição da tecnologia no mundo mercantilizado, ou seja, o medicamento que deveria contribuir para acabar com as doenças, gera, ele mesmo, uma epidemia. Na sociedade unidimensional estudada por MARCUSE (1967), a dimensão do agente quimioterápico é sufocada pelas outras dimensões.

As denúncias que emergem no debate sobre o URM, como existência de produtos desnecessários, produtos perigosos, uso incorreto (prescrições irracionais e automedicações), falta de acesso às populações mais carentes e sua utilização irracional, são conseqüências da produção administrada diretamente por estes produtores isolados de mercadorias e não pela sociedade (RUBIN, 1980). A sociedade não determina o que e quanto vai ser produzido. Assim cada produtor de mercadorias é formalmente livre para produzir qualquer produto que queira. E conforme TEIXEIRA (1995), a produção e a distribuição de toda a riqueza social passam a ser regidas pelo processo de troca de coisas, por essa coisificação, não obedecendo às necessidades de um todo social, e sim, das vantagens pessoais que cada produtor independente tenta arrancar desta relação. Ocorre uma autonomização de produção e distribuição das riquezas, passando a ser regida por leis independentes da vontade pessoal ou de políticas para um todo social.

Porém, como acrescenta RUBIN (1980), quando o "produtor independente leva o produto final ao mercado para trocá-lo, ele não é livre para determinar as proporções da troca, ficando condicionado as flutuações do mercado". Daí, surge o fenômeno da planificação na esfera do consumo, pela criação das falsas necessidades, como visto em MARCUSE (1967).

Por isso, as análises de crescimento de mercado, como mostrado no capítulo um, apontam sempre para mercados ricos (os países 
desenvolvidos), produtos para fins específicos ou ainda para populações idosas dos países em desenvolvimento. Para minimizar o problema que o produtor independente tem com o condicionamento da flutuação de mercado, se planeja não somente a produção, mas também, o mercado consumidor, dirigindo as necessidades dos mercados potenciais (ou mais ricos) através de produtos específicos - os medicamentos para doenças que são agora determinadas para estes mercados, como depressão, disfunção sexual e colesterol - em detrimento de efetivas necessidades terapêuticas que podem estar centradas nos mercados mais "incertos" (pobres e/ou inconstantes), o que se caracteriza como "flutuações de mercados". Esta análise revela o predomínio da dimensão mercadoria, produzindo, por um lado, dificuldade do acesso, enquanto dimensão agente quimioterápico, para muitos que precisam e, por outro lado, a contraposição: acesso excessivo e irracional por necessidades manipuladas do mercado ao consumidor e não ao cidadão.

Segundo ENGELS (apud TEIXEIRA, 1995), este movimento altera todos os vínculos morais da sociedade, destruindo valores humanos em benefício de valores de troca, substituindo-se os princípios éticos pelos princípios de concorrência, no qual as leis anteriores são substituídas pelas leis de oferta e procura. A humanidade se converte em mercadoria.

Num exercício de reflexão sobre as dimensões do medicamento vistas em LEFRÈVRE (1991), comparando-as com os conceitos de MARX (1985), poderíamos dizer:

- A dimensão agente quimioterápico é o valor de uso, como forma de satisfazer uma necessidade social;

- A dimensão mercadoria é o valor de troca, como forma de satisfazer a necessidade do produtor permutar o medicamento por qualquer outra mercadoria; 
- A dimensão simbólica é, ao mesmo tempo, integrante destas duas dimensões anteriores e o elo entre elas. Ela tende a ser um agente articulador das relações entre estas dimensões, pois evoca, por um lado, a satisfação da necessidade social determinada de acordo com o interesse estabelecido e, por outro lado, evoca a possibilidade de atender a satisfação do produtor, garantindo a permutabilidade do medicamento, enquanto dimensão mercadoria.

A dimensão simbólica serve bem numa sociedade de pensamento reificado, pois segundo HORKHEIMER (1976), quanto mais as idéias se tornam automáticas, instrumentalizadas, menos alguém vê nelas pensamentos com algum significado próprio. Dessa forma, a doença tornase, como tudo nesta sociedade, desprovida de significados, um "algo" mecânico, do tipo "liga/desliga", plausível de ser transformada em saúde "ao girar de um botão" (ou, com a administração de um medicamento). Quanto mais este conceito de razão se torna emasculado, mais facilmente ela se presta à manipulação ideológica, à propagação de uma verdade totalitária, mercantil. As necessidades são conduzidas em função de forças econômicas cegas com único objetivo: valorização do valor. A propaganda científica, reificada, faz da opinião pública um simples instrumento de forças obscuras, surgindo como um substitutivo da razão.

Do ponto de vista da razão formalizada, na qual uma atividade (agora sem significado próprio) só é racional quando serve a outro propósito como, por exemplo, a saúde ou o descanso como auxiliadores na recuperação da energia produtiva, a saúde não é vista como saúde em si. Ela torna-se objeto de interesse a servir outro propósito: a prontidão humana para o processo produtivo, o corpo que precisa do rápido restabelecimento mecânico para voltar ao ambiente de produção.

Partindo dos desejos tais como eles são realmente, ou seja, condicionados por todo o sistema social no qual as pessoas vivem, a satisfação reificada é, no mínimo, diferente da verdade objetiva e transformada em critério de verdade; ela fornece uma base fantasiosa, um 
parâmetro falso, porém aparentemente verdadeiro e imune a sua falsidade. Ou seja, a satisfação torna-se igual à verdade.

O capítulo um mostra, materialmente, como as práticas comerciais em todos os níveis, facilita a expansão da mercantilização da doença:

- As consultas médicas quase sempre implicam em prescrição de medicamento, tornando-o hegemônico no tratamento;

- A existência de medicamentos sem eficácia comprovada disponíveis no mercado;

- Estabelecimentos farmacêuticos tratados somente como algo mercantil, onde ainda se pratica a empurroterapia (prática comercial totalmente descompromissada com a ética) e a automedicação;

- "Novos produtos" colocados no mercado como necessidade concorrencial, independente de suas reais vantagens. Os "novos produtos", como visto no debate, são estratégicos apenas para justificar o aumento de preços e a extensão de suas patentes;

- Os gastos com mercadização ${ }^{89}$ sempre muito superiores se comparados com os gastos com pesquisa;

- A promoção de medicamentos, embora disfarçada de educacional, demonstra, na prática, como algo desorientador, força 0 estabelecimento de políticas (OMS, ANVISA) domesticadoras $^{90}$ do mercado.

\footnotetext{
${ }_{90}^{89}$ Mercadização como tradução de marketing, como explicado na $17^{a}$ nota de rodapé.

90 Domesticar tem o sentido de amansar, domar, ou ainda, civilizar. Novo dicionário Aurélio de Língua Portuguesa. Curitiba: Positivo, 2004.
} 
De qualquer forma, é interessante observar que, embora a expansão da mercantilização da doença se intensificou no início dos anos 80 , sua construção histórica tem relação com o berço do capitalismo. Os medicamentos modernos nascem num contexto que fortalecem sua tendência ao caráter comercial. A palavra nostrum reflete a ideologia implícita no seu duplo sentido: o conceito "nosso" enquanto propriedade e enquanto melhor solução.

A história dos medicamentos constitui-se sobre a confusão na ciência, o protecionismo patenteário e a promoção. O trecho do CORRY (apud PARTRIGE, 1970), sobre a passagem do mascate, ilustra como a venda do medicamento é, historicamente, acompanhada por uma espécie de show, no qual, independente de comprovações científicas sérias, as pessoas o adquiriam sob um poder místico, uma coisa fantasiosa, uma abstração que Ihes fazia crer na cura, a falsa necessidade criada pelo fetiche da mercadoria, articulada pela dimensão simbólica do medicamento. Esta relação é parecida, por exemplo, com o caso da Disfunção Sexual Feminina, em que, apesar de não haver consenso sobre a existência da doença, a cura é amplamente divulgada e utilizada.

A intensificação do debate sobre a mercantilização da doença é claramente regida por uma lógica de mercado e ambientada neste espaço: a questão das patentes no centro do capitalismo (EUA), a consolidação da idéia de vencedores e perdedores (típico da ideologia concorrencial) e os lobbyes apresentando-se como solução para a possível crise do capital.

As universidades e os pesquisadores unem-se à concepção de vencedores e perdedores e revelam a totalização do pensamento reificado, pois até a ciência, que deveria ser um espaço de auto-reflexão, é abarcada por este pensamento.

O fato da indústria farmacêutica ser a mais lucrativa das empresas mostra que ela, nos moldes que se apresenta atualmente, responde a uma lógica de valorização do valor, do valor de troca. Para isso, ela aproveita basicamente de três aspectos: o aspecto simbólico do medicamento, o aspecto confuso de determinação da saúde (conceito que, certamente, não 
se determinará pela lógica técnica) e o mecanismo protecionista das patentes. Paralelo a isto, a ilusão de ser a indústria inovadora e pesquisadora, reforça sua capacidade determinadora de "estilo de vida", o que propicia, inclusive, ambiente para uma prática usual de aumento de preços.

Os consensos médicos, com a ciência já reificada, são utilizados como mediação material. Isso pode ser visto nas constantes redefinições sobre os níveis de "colesterol alto", sobre as novas categorias de disfunção sexual feminina e de transtorno bipolar. E, ainda que não haja consenso, basta à indústria a simples suposição da doença, isto já lhe serva para propagar a enfermidade como se esta fosse a "última roupa da moda". Aplica-se a esta situação, os caso da DSF e do transtorno bipolar.

Novas ciências são criadas, como a "medicina sexual". A clínica de Laura Bergman de "saúde sexual da mulher" com serviços médicos, spa e yoga, bem nos lembra as formas alternativas de vida citadas por MARCUSE (1967), uma negação inofensiva, como parte salutar da dieta do status quo.

Toda e qualquer idéia funciona para este sistema, como o uso off label que, pode até ter tido uma necessidade real em sua origem, mas se tornou um artifício poderoso para a indústria, uma vez que cria falsa ilusão de poder ao médico, que acredita prescrever aquilo que "ele quer".

Novas formas de mediações são estabelecidas: entidades de autoajuda (caso da síndrome das pernas inquietas) e entidades de professores (caso da TDAH) são fortemente patrocinadas pela indústria como meios de alimentar falsas necessidades.

O trecho a seguir, extraído de LEVÈFRE (1991) resume, em essência, o fenômeno da mercantilização da doença. "Com efeito, nessas sociedades, a ninguém é permitido sentir-se verdadeiramente saudável porque estará sempre 'faltando algo' (no plano orgânico, mental, estético, comportamental, etc.); haverá sempre uma sensação de vazio, a ser preenchido por algum serviço ou mercadoria".

A criação da falsa necessidade, como na época dos nostruns em que o mascate se aproveitava de sua hilaridade para vender suas pílulas, toma 
outros contornos na modernidade. A associação da Pfizer com celebridades revela o princípio de uma sociedade de imagens, de encantamento, em que a utopia de sucesso burguês mostra toda sua robustez. 


\section{CONSIDERAÇÕES FINAIS}

"Com quantos quilos de medo se faz uma tradição?"

(Senhor Cidadão. Tom Zé. LP Tom Zé. 1972)

A mercantilização da doença faz parte de um processo global de avanço do sistema capitalista. Fazer avançar a racionalidade que o rege é a forma mais eficaz e refinada para sua reprodução. Abarcar o pensamento para que a esfera do consumo seja colocada como única opção de existência, transformando o consumo numa peça definitiva da produção planejada é exatamente o mecanismo de estabelecimento deste sistema na era industrial, encontrado nas reflexões de MARCUSE (1967): a formatação de um homem unidimensional.

A vida, em sua totalidade, como um grande chão de fábrica. Este é o sentido exato da transformação do consumo em estilo de vida. $O$ melhor estilo de vida possível, enquanto "maneira peculiar de viver" sob a ótica do capitalismo, é o estilo "consumidor".

Este estilo de vida, quando aplicado aos medicamentos, por todas as considerações feitas até aqui, mostra-se muito perigoso.

As iniciativas de enfrentamento deste avanço, mostradas no capítulo um (debate sobre o URM), são superadas pelo avanço da mercantilização da doença, pois o poder de abarcar o pensamento, contido no mecanismo de reprodução da lógica capitalista, como discutido, é poderoso, indo além do debate do URM, desvirtuando-o. Por isso ele avança em conformações cada vez mais agudas e precisas.

Esta dissertação mostrou ainda que:

- A mercantilização da doença tende a desvirtuar progressivamente os parâmetros fixados para o URM; 
- a medicalização da sociedade favorece a mercantilização da doença, porém elas reforçam-se mutuamente e, nesse processo de determinação recíproca, a racionalidade técnica reconfigura a prática e o saber médicos;

- O fenômeno da medicalização, invadindo as diferentes instâncias da vida social, estabelece um certo saber e uma certa prática da medicina, ambos já determinados pela racionalidade constitutiva da mercantilização;

- A mercantilização da doença permite vislumbrar ainda a colonização econômica de outras esferas da sociedade, tais como a educação, a política e a ciência, que reforça e possibilita a colonização econômica do sistema de saúde da sociedade contemporânea.

Uma política real de enfrentamento a estas questões deve considerar todos os aspectos aqui abordados. A transformação deve começar pela mudança do pensar o mundo e a vida, repensando o processo saúdedoença e estabelecendo práticas médicas que superem as determinações estabelecidas pela racionalidade técnica. 


\section{REFERÊNCIAS}

ANGELL, M. The truth about the drug companies. New York: Random House, 2004.

ANVISA, Agência Nacional de Vigilância Sanitária. Projeto de Monitoração de Propaganda e Publicidade de Medicamento - Fase I. 2002. Disponível em: < http://www.anvisa.gov.br/propaganda/fase 1.htm>. Acesso em: 22 jan. 2008.

ANVISA, Agência Nacional de Vigilância Sanitária. Resolução RDC oㅜ 140, de 29 de maio de 2003. Disponível em: <http://elegis.anvisa.gov.br/leisref/public/showAct.php?id=6311>. Acesso em: 14 jan 2008.

ANVISA. Agência Nacional de Vigilância Sanitária. Câmara Técnica de Medicamentos - CATEME. , 2005. Disponível em: $<$ http://www.anvisa.gov.br/medicamentos/cateme/cateme cateme.htm>. Acesso em: 05 jan 2008.

APPLBAUM, K. Pharmaceutical marketing and the invention of the medical consumer. Disease mongering serie-vol. 3,issue 4. Public Library of Science Medicin. [artigo na Internet]. 2006. Disponível em: $<$ http://medicine.plosjournals. Org/perlserv/?request=getdocument\&doi=10.1371/journal.pmed.0030189 > . Acesso em: 25 mai 2006.

ARAUJO, A. Serviços residenciais terapêuticos em saúde mental: um estudo etnográfico sobre as moradias de Campinas-SP. 2004. Tese (Doutorado em Psicologia) - Universidade Federal do Espírito Santo, Espírito Santo. 
ARONSON, J.K. An agenda for research on adverse drug reactions. British Journal of Clinical Pharmacology, 64 (2): 119-121, 2007.

ARRAIS, P. S. D. e col. Perfil da automedicação no Brasil. Rev. Saúde Pública, 31 (1): 71-7, 1997.

BARKER, L.F. Medical laboratories: their relations to medical practise and to medical discovery. Science, 27 (694): 601-11. (artigo na Internet). 1908. Disponível em:

$<$ http://www.sciencemag.org/cgi/content/citation/27/694/601>. Acesso em 2 fev 2008.

BERMUDEZ, J. Indústria Farmacêutica, Estado e Sociedade. São Paulo: Hucitec, 1995.

BERMUDEZ, J. Remédios: saúde ou indústria? A produção de medicamentos no Brasil. Rio de Janeiro: Relume Dumará, 1992.

BOARINI, M.L. e YAMAMOTO, O. H. Higienismo e Eugenia: discursos que não envelhecem. Psicologia Revista, São Paulo, 13(1): 59-72, 2004.

CAMARGO, E.A., ZANINI, A.C. e CIOLA-SANCHEZ, L. Avaliação qualitativa no uso de medicamentos. Semina 12 (2): 78-83, jun. 1991.

CASTRO, C.G.S.O. (Org). Estudos de utilização de medicamentos: noções básicas. Rio de Janeiro: Editora Fiocruz, 2000.

CEATOX - Centro de assistência toxicológia do Hospital das Clínicas. Estatísticas [relatório na Internet]. São Paulo, 1996. Disponível em: $<$ http://med.fm.usp.br/dim/homepage/a105/Estatis.htm>. Acesso em: 10 jan 2008. 
COHEN, G.A. Karl Marx's Theory of history, a defence. New York: Oxford University Press Inc., 1978.

CORDEIRO, H. A indústria da saúde no Brasil. Rio de Janeiro: Graal, 1980.

CRF-SP - Conselho Regional de Farmácia do Estado de São Paulo. Fracionamento: medicamentos na dose exata. São Paulo: Revista do Farmacêutico n² 26, junho/julho de 2005.

DEMBER. A. Public handouts enrich drug makers, scientists. Boston: The Boston Globe; 5 de abril 1998, A1.

DOSSEY, L. Listerine's Long Shadow: Disease Mongering and the Selling of Sickness. Explore, Philadelphia, 2 (5): 379-385, set-out, 2006.

FEFER, E. Uso Racional de Medicamentos. In: SOBRAVIME - Sociedade Brasileira de Medicamentos. Medicamentos e a reforma do setor saúde, Sociedade Brasileira de medicamentos. São Paulo: HUCITEC, 1999.

GARCIA, G.G. Remedios politicos. Buenos Aires: Isalud, 1994.

HAI - Health Action International. Mission Statement. (relatório na Internet). Disponível em: <http://www.haiweb.org/missionStatement.html>. Acesso em: 05 jan 2008.

HEALY, D. The latest mania: selling bipolar disorder. Disease mongering serie - vol. 3,issue 4. Public Library of Science Medicin. (artigo na $\quad$ Internet). Disponível em:

$<$ http://medicine.plosjournals.Org/perlserv/?request=getdocument\&doi=10.1371/journal.pmed.0030185> . Acesso em: 25 mai 2006. 
HORKHEIMER, M. Eclipse da razão. Rio de Janeiro: Labor, 1976.

ILLICH, I. A expropriação da saúde: Nemesis da medicina. Rio de janeiro: Nova Fronteira, 1975.

INDÚSTRIA farmacêutica: Um retrato das transformações do mercado (relatório na Internet). São Paulo, 2007b. Disponível em: $<$ http://www.farmacia.com.pt/index.php?name=News\&file=article\&sid=4267>. Acesso em: 05 jan 2008.

LAPORTE, JR e TOGNONI, G. Principios de epidemiologia del medicamento. 2.ed. Barcelona: Salvat, 1993.

LEFÈVRE, F. O medicamento como mercadoria simbólica. São Paulo: Cortez, 1991.

LEXCHIN, J. Uma fraude planejada: a publicidade farmacêutica no terceiro mundo. In: BONFIM, J. R. A. e MERCUCCI, V.L. (Org) A construção da política de medicamentos. São Paulo: Hucitec/Sobravime, 1997.

LEXCHIN J. Bigger and better: how Pfizer redefined erectile dysfunction. Disease mongering serie - vol. 3,issue 4. Public Library of Science Medicin. (artigo na Internet). 2006. Disponível em: $<$ http://medicine.plosjournals. Org/perlserv/?request=getdocument\&doi=10.1371/journal.pmed.0030132>. Acesso em: 25 mai 2006.

LUKÁCS, G. História e consciência de classe. São Paulo: Martins Fontes, 2003. 
MACHADO-DOS-SANTOS, S. C. Melhoria da eqüidade no acesso aos medicamentos no Brasil: os desafios impostos pela dinâmica da competição "extrapreço". 2001. Dissertação (Mestrado em Saúde Pública) - Escola Nacional de Saúde Pública/Fundação Oswaldo Cruz, Rio de Janeiro.

MARCUSE, H. A ideologia da sociedade industrial. Rio de Janeiro: Zahar, 1967.

MARX, K. O Capital: crítica da economia política. São Paulo: Nova Cultural, 1985.

MELO M. A promoção da doença. A quem interessa? Rev Port Clin Geral, 23:361-4, 2007.

MERCADO mundial cresceu 7\% no ano passado (relatório na Internet). São Paulo, 2007a. Disponível em: $<$ http://www.farmacia.com.pt/index.php?name=News\&file=article\&sid=2467 $>$. Acesso em: 05 jan 2008.

MINISTÉRIO DA SAÚDE. Portaria MS № 1.555, de 27 de junho de 2007 Institui o Comitê Nacional para a Promoção do Uso Racional de Medicamentos.

Disponível em:<http://portal.saude.gov.br/portal/arquivos/pdf/portaria gm 1555.pdf $>$. Acesso em: 05 jan 2008. 
MINISTÉRIO DA SAÚDE. Agência Nacional de Vigilância Sanitária. Gerência de Monitoramento e Fiscalização de Propaganda, Publicidade, Promoção e Informação de Produtos Sujeitos à Vigilância Sanitária. Estudo comparado: regulamentação da propaganda de medicamentos / Ministério da Saúde, Agência Nacional de Vigilância Sanitária, Gerência de Monitoramento e Fiscalização de Propaganda, Publicidade, Promoção e Informação de Produtos Sujeitos à Vigilância Sanitária (Série E. Legislação de saúde). Brasília: Ministério da Saúde, 2005.

MINISTÉRIO DA SAÚDE. Secretaria de Ciência, Tecnologia e insumos Estratégicos. Departamento de Assistência Farmacêutica e Insumos Estratégicos. Rename 2006: O processo de revisão e atualização. [relatório na Internet]. Brasília: Ministério da Saúde, 2006. Disponível em: $<$ http://portal.saude.gov.br/portal/arquivos/pdf/texto_rename_manoel_nov200 6>. Acesso em: 04 jan 2008.

MINISTÉRIO DA SAÚDE. Secretaria de Ciência, Tecnologia e Insumos Estratégicos Departamento de Ciência e Tecnologia. Saúde no Brasil Contribuições para a Agenda de Prioridades de Pesquisa/Ministério da Saúde. Série B. Textos Básicos de Saúde. Brasília: Ministério da Saúde, 2004.

MOYNIHAN, R. e col. Selling sickness: the pharmaceutical industry and disease mongering. BMJ (British Medical Journal), 324: 886-961, 2002.

MOYNIHAN, R. e CASSELS, A. Selling sickness: How the World's Biggest Pharmaceutical Companies are Turning Us All into Patients. New York: Nation Books, 2005. 
MOYNIHAN, R. e HENRY, D. The fight against disease mongering: generating knowledge for action. Disease mongering serie-vol. 3,issue 4. Public Library of Science Medicin. (artigo na Internet). 2006. Disponível em: $<$ http://medicine.plosjournals.Org/perlserv/?request=getdocument\&doi=10.1371/journal.pmed.0030191>. Acesso em 25 mai 2006.

NASCIMENTO, A.C. Ao persistirem os sintomas o médico deverá ser consultado: isto é regulação? 2003. Dissertação (Mestrado em Medicina Social) - Instituto de Medicina Social da Universidade do Estado do Rio de Janeiro, Rio de Janeiro.

NOVO DICIONÁRIO AURÉLIO DE LÍNGUA PORTUGUESA. Curitiba: Positivo, 2004.

OLIVEIRA, M.A. e col. Talidomida no Brasil: vigilância com responsabilidade compartilhada? Cad. Saúde Pública, Rio de Janeiro, 15(1):99-112, jan-mar, 1999.

OMS. Organização Mundial da Saúde. Uso racional de los medicamentos: informe de una conferencia de expertos. Nairobi, 25-29 de noviembre de 1985. Ginebra, Organización Mundial de la Salud, 1987.

OMS. Organização Mundial da Saúde. Criteria for Medicinal Drug Promotion. 1988. (relatório na Internet). Disponível em: <http://www.who.int/medicinedocs/index.fcgi?sid=vW\%2egmvyq9ee80ca600 0000004794bd7d\&a=d\&d=Jwhozip08e $>$. Acesso em: 21 jan 2008.

OMS. Organização Mundial da Saúde. Progresos realizados en el uso racional de los medicamentos - Informe de la Secretaría. 60a MUNDIAL DE LA SALUD A60/24 Punto 12.17 del orden del día provisional 22 de marzo de 2007. 
OMS. Organização Mundial da Saúde. Essential Medicines List (EML). 2008 (relatório na Internet). Disponível em: $<$ http://www.who.int/mediacentre/factsheets/fs325/en/index.html>. Acesso em: 04 jan 2008.

OPAS. Organização Pan Americana de Saúde. Declaração de Alma-Ata Conferência Internacional sobre cuidados primários da saúde Alma-Ata, URSS, 6-12 de setembro de 1978. (relatório na Internet). Disponível em: $<$ http://www.opas.org.br/coletiva/uploadArg/Alma-Ata.pdf $>$. Acesso em 03 jan 2008.

PARTRIDGE, E. A covey of Partridge: an anthology. Manchester: Ayer Publishing; 1970 - reimpressão de 1937. (livro parcialmente na Internet). Disponível em: <http://books.google.com/books?id=LjArpHylMt4C\&hl=ptBR>. Acessado em: 03 fev 2008.

PAYER, L. Disease mongers: how doctors, drugs companies, and insurers are making you feel sick. New York: Jonh Wiley \& Sons, 1992.

PHILLIPS, C.B. Medicine goes to school: teachers as sickness brokers for ADHD. Disease mongering serie-vol. 3,issue 4. Public Library of Science Medicin. (artigo na Internet). 2006. Disponível em: $<$ http://medicine. plosjournals. Org/perlserv/?request=getdocument\&doi=10.1371/journal.pmed.0030182>. Acesso em: 25 mai 2006.

PORTO M. P. Eqüidade na distribuição geográfica dos recursos em saúde: Uma contribuição para o caso brasileiro. 1997. Tese (Doutorado em Saúde Pública) - Escola Nacional de Saúde Pública/Fundação Oswaldo Cruz, Rio de Janeiro. 
PUBLIC CITIZENN. Rx R\&D Myths: The Case Against The Drug Industry's R\&D “Scare Card”. Washington, D.C. (relatório na Internet). $2001 . \quad$ Disponível em: $<$ http://www.citizen.org/search/index.cfm?RequestTimeout=180> . Acesso em: 02 março 2008.

RACED, K. Pathologies, commodities, and the politics of evaluation. Abstracts from the inaugural conference on disease mongering. Newcastle. (relatório na Internet). 2006. Disponível em: $<$ http://www.diseasemongering.org/downloads/abstracts.pdf $>$. Acesso em: 13 dez 2006.

ROMANO-LIEBER, N.S. e col. Revisão dos estudos de intervenção do farmacêutico no uso de medicamentos por pacientes idosos. Cad. Saúde Pública, Rio de Janeiro, 18(6):1499-1507, nov-dez, 2002.

ROSDOLSKY, R. Gênese e estrutura de 0 Capital de Karl Marx. Rio de Janeiro: Contraponto, 2001.

ROZENFELD, S. O uso de medicamentos no Brasil. In: Laporte JR e col. Epidemiologia do medicamento: Princípios gerais. São Paulo/Rio de Janeiro: Hucitec/Abrasco, 1989a.

ROZENFELD, S. Avaliação do uso dos medicamentos como estratégia para a reorientação da política de insumos em saúde. Cad. Saúde Pública, Rio de Janeiro, 5(4): 388-402, out-dez, 1989b.

RUBIN, II. A Teoria Marxista do valor. São Paulo: Brasiliense, 1980.

SANTI, V. Medicamentos: verso e reverso da propaganda. Ponta Grossa: UEPG, 1999. 
SAYD J.D. Mediar, Medicar, Remediar: aspectos da terapêutica na medicina ocidental. 1995. Tese (Doutorado em Medicina Social) - Instituto de Medicina Social da Universidade do Estado do Rio de Janeiro, Rio de Janeiro.

SILVA, A. S. T. A emergência do acompanhamento terapêutico: o processo de constituição de uma clínica. 2005. Dissertação (Mestrado em Psicologia Social) - Universidade Federal do Rio Grande do Sul, Porto Alegre.

SILVA, A. S. T. e SILVA, R. N. A emergência do acompanhamento terapêutico e as políticas de saúde mental. Psicologia ciência e profissão, 26 (2): 210-221, jun, 2006.

SILVA, L.R. Conhecimentos e atitudes dos farmacêuticos sobre a regulamentação da profissão e funcionamento de drogarias - uma abordagem sanitária. 2002. Dissertação (Mestrado em Medicina) Faculdade de Medicina de Ribeirão Preto da Universidade de São Paulo, Ribeirão Preto.

SILVA, R. C. S. Medicamentos Excepcionais no âmbito da assistência farmacêutica no Brasil. 2000. Dissertação (Mestrado em Saúde Pública) Escola Nacional de Saúde Pública/Fundação Oswaldo Cruz, Rio de Janeiro.

SINITOX - Sistema Nacional de Informações Tóxico-Farmacológicas. Casos Registrados de Intoxicação Humana por Agente Tóxico e Trimestre. Brasil, Rio de Janeiro. (relatório na Internet). 2005. Disponível em: $<$ http://www.fiocruz.br/sinitox/2005/brasil2005.htm>. Acesso em: 10 jan 2008.

SOBRAVIME - Sociedade Brasileira de Medicamentos. O que é uso racional de medicamentos. São Paulo: Sobravime e Acción Internacional para la Salud-América Latina y El Caribe, 2001. 
SOUSA, J.C. Do peixe no prato à cana de pesca. Reflexões sobre empoderamento, capacitação e cuidados de saúde. Rev Port Clin Geral, 23:353-8, 2007.

TEIXEIRA F.J.S. Pensando com Marx: uma leitura crítico-comentada de o capital. São Paulo: Ensaio, 1995.

TESSER, C.D. Medicalização social (I): o excessivo sucesso do epistemicídio moderno na saúde. Interface - Comunic, Saúde, Educ, São Paulo. 10(19): 61-76, jan/jun 2006.

THE AMERICAN HERITAGE DICTIONARY OF THE ENGLISH LANGUAGE. New York: American Heritage Publishing Co. Inc., 1969.

THE CENTER FOR PUBLIC INTEGRITY. Drug lobby second to none. (relatório na Internet). 2005. Disponível em: $<$ http://www.publicintegrity.org/Content.aspx? src=search\&context=article\&id= 723>. Acesso em: 27 jul 2005.

THE CENTURY DICTIONARY - AN ENCYCLOPEDIC LEXICON OF ENGLISH LANGUAGE. New York: The Century Co., 1914.

TIEFER, L. Female sexual dysfunction: a case study of disease mongering and activist resistance. Disease mongering serie - vol. 3 , issue 4. Public Library of Science Medicin. (artigo na Internet). 2006. Disponível em: $\quad<$ http://medicine.plosjournals.Org/perlserv/?request=getdocument\&doi=10.1371/journal.pmed.0030178> . Acesso em: 25 mai 2006. 
TOGNONI, G. e LAPORTE, JR. Estudos de utilização de medicamentos e de farmacovigilância. In: LAPORTE, JR e col. Epidemiologia do medicamento: Princípios gerais. São Paulo/Rio de Janeiro: Hucitec/Abrasco, 1989.

WANNMACHER L. Erros: evitar o evitável. Boletim. Uso racional de medicamentos: temas selecionados. v. 2, oㅜ 7. Brasília: Organização Pan Americana de Saúde/MS, 2005.

WOLOSHIN, S. e SCHWARTZ, L. M. Giving legs to restless legs: A case study of how the media helps make people sick. Disease mongering serie - v. 3, n. 4. Public Library of Science Medicin. (artigo na Internet). 2006. Disponível em: <http://medicine.plosjournals.Org/perlserv/?request=getdocument\&doi=10.1371/journal.pmed.0030170>. Acesso em: 25 mai 2006.

YOUNG, J. H. The Toadstool Millionaires: A Social History of Patent Medicines in America before Federal Regulation. (livro na Internet em 2002). 1961. Disponível em: <http://www.quackwatch.org/13Hx/TM/00.html>. Acesso em: 11 fev 2008.

ZINNER, D. E. Medical R\&D at the turn of the millennium. Health Affairs, vol. 20, no 5; Set - Out, 2001. 


\section{ANEXO}

Campanha publicitária para popularizar a andropausa deflagrada em novembro de 2006 pela empresa Shering, do grupo Bayer Shering Pharma. Esta campanha ilustra a venda de estilo de vida.

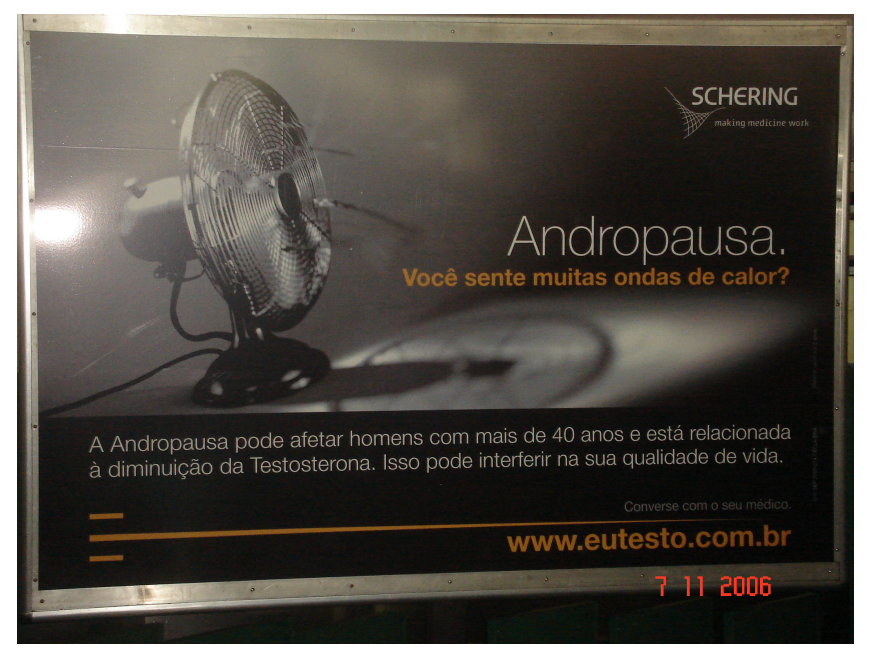

Figura 1. Peça publicitária 1 - Imagem: ventilador. Mensagem: você sente muitas ondas de calor?

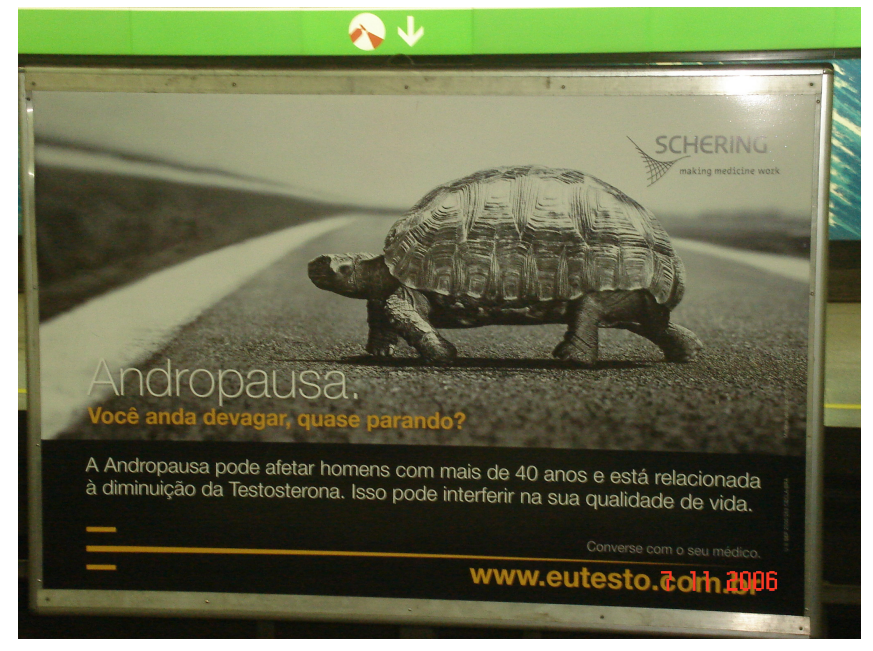

Figura 2. Peça publicitária 2 - Imagem: tartaruga. Mensagem: você anda devagar, quase parando? 


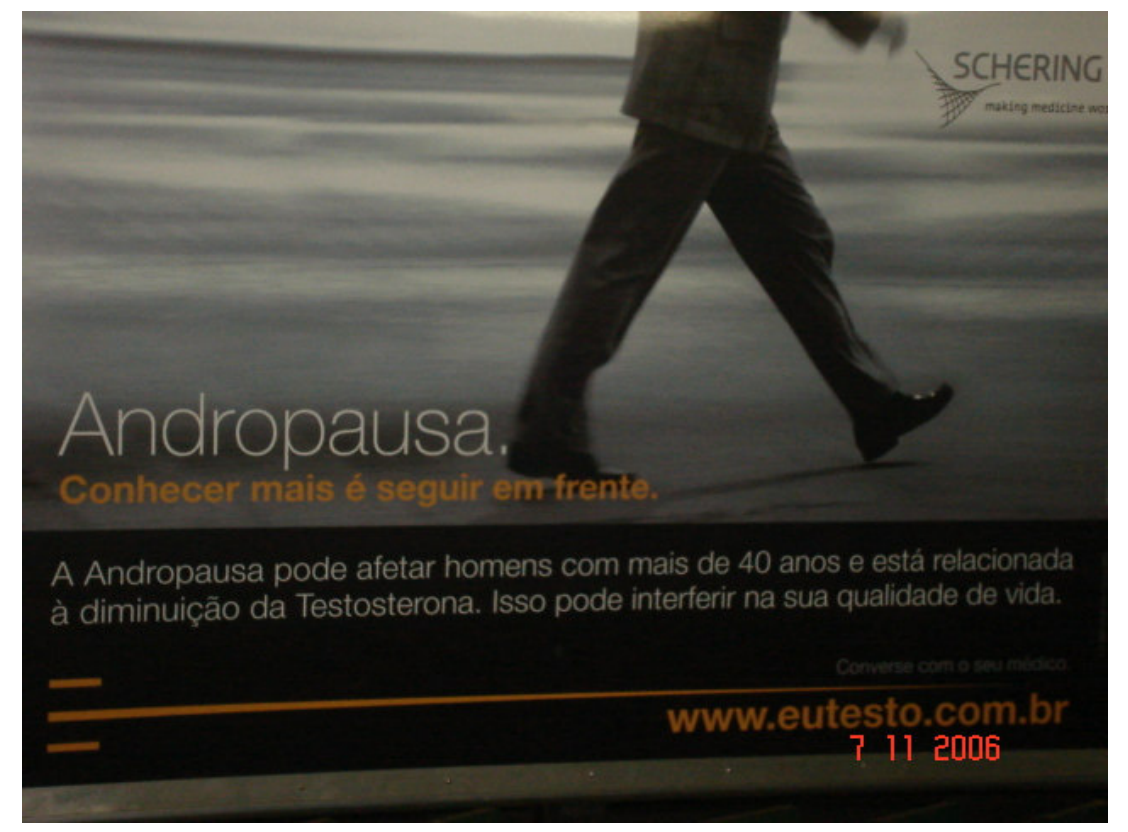

Figura 3. Peça publicitária 3 - Imagem: homem andando pela praia. Mensagem: conhecer mais é seguir em frente.

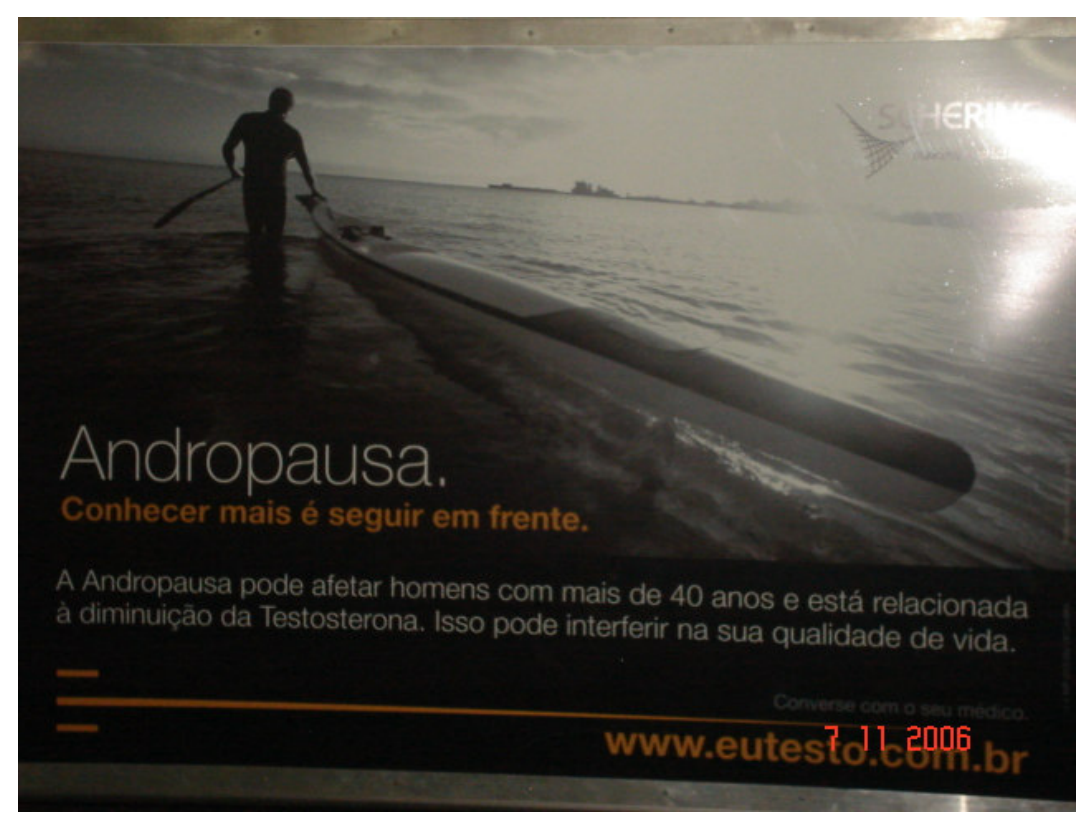

Figura 4. Peça publicitária 4 - Imagem: homem arrastando caique. Mensagem: conhecer mais é seguir em frente. 